室町幕府所務沙汰とその変質

る訟数て 所

府幕 個 幕雅

葆別府沙

中権領

世力主招

社㤎のこは

会 ぞ存な

Kの在つ所

位上芰七領

置亏前 $心$ 知

的提た行

忖対之審や

忘卞議年

そしる。顡

のた中決納

性の世裁入

格か社のな

老々会手 ど

考いの続に

兄ここの関

る点とこす

際はをる

にこで訴

重公ら市訟

要権しるに

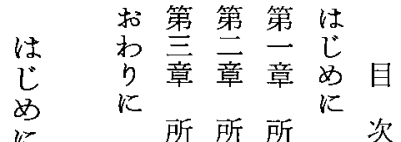

に

所哲務 務

沙沙沙

汰 汰

変 機 機

殿関

の 9

意衰 制

義退度

$z \varepsilon$ 的

紧個営

刑衣

室

叢

田丁

草

府

可

枒

沙

汰

文

の

变

䝷

説

要た訴多い

質

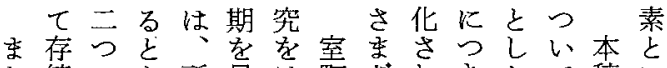
た続のと所見注町ざれきたて稿い 寸機手務通じ幕委た當制とで党 窒る関に沙专わ府な場議度く取よ

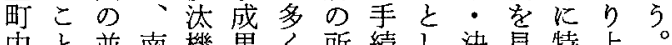

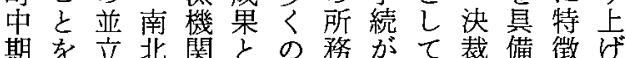

の指于朝のし蓄沙整わ导し的る

義摘る条変て積汰備ざるてな堂

教し体期遷重がにさわ場いの町

期た制頃を要あつれざがたは幕

の。热に跡なる塱七整、こ、府

政成将ら゙のがてい借評とその

務立軍けは怙た怘定でれ前

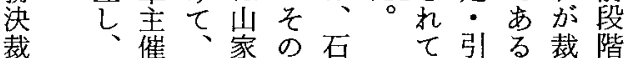

の その引浩な井括付。判

あ社付樹か良りなそと鐮

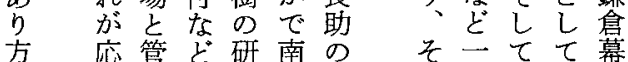

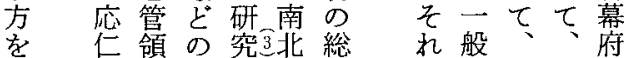

検頃主衰で朝合に政こあの

討杰萑退あ期的と務 5 る所

しでのをるか制るかし程務

安場指。5度な5た度沙

将定の摘山室史分訴整汰

徽

軍し、幏町研て節訟然に 


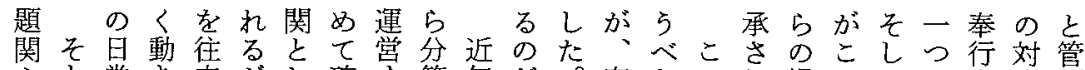
心す常さ来肪し確す節年だ。室きの机場のての人応領 のそ的でし、て認る化、ろし町枠よたを設敨しがの 背す式あ、設まさかさ鎌 5 か期組 5 女中つ楽治と進あ

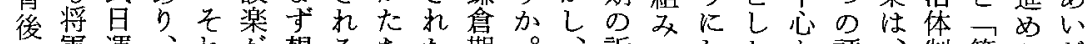
に電運、杂想るるた期。、訴はしたと評、制管らたた

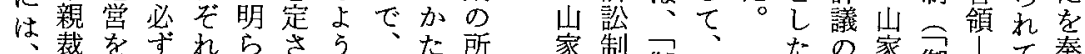

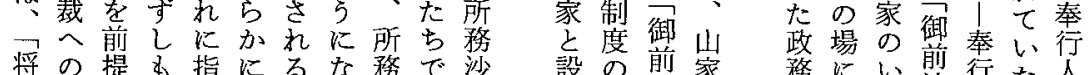
将の提む指にるな務で沙設の前家務に心前行た人 軍 プとこ示しのう沙制汰 がロしうをたはて汰度に

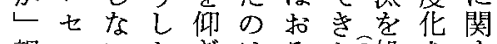
親スいたきはそた処さす 裁を制な、ら先理杂 跡の度が奉く山寻た研 管今の的ら行こ家る場究

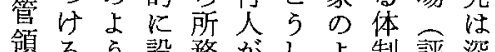

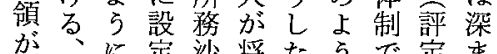
分、に定沙将た 5 で定市

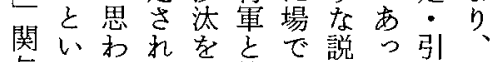
与ら処管あ明た付一

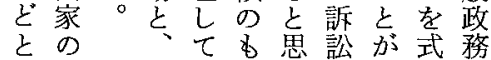
楽骨沙の の格 汰 説索体三 は示制亏 順守 の 評 当の構議 に之成 墥 接し要場 合て素並 高々立 るとし説 \& $\circlearrowright \tau$ の 後でと と通はで い説市 当 光化るい 决照う沙人气が 裁㥕染体气行 のす将制と毟学 ある草しいみ来 方し催を云たて が、の構らし指 義場成のた尔 以満芴し評設を 後期六七議設何 の管いの潘ざ 室成領た場熏? 町立䇈立唯は? 幕乞催評連将訴 淂しし軍訟

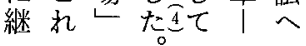

様をが質ら性応がない的討なけ常分設不のの政— な考、そを格安指とる秩すなあ継的節楽十質と治誰

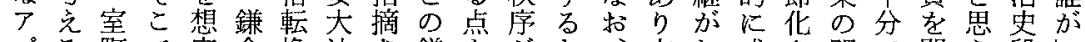

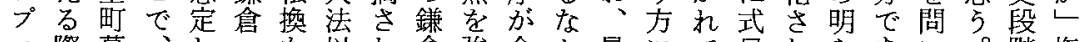
口際幕、し・を以れ倉強会か最にて日れらあい。階権 1の府本た室み後て幕調議で近差い運たかる直しを限 千手に稿方町い残い府豆体引で兾た営加に。そか模を

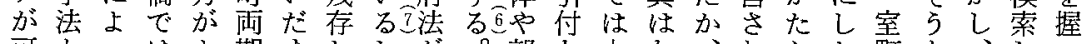

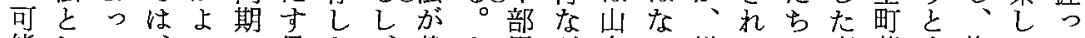
能して、いの見な、裁を局を家い鎌るで事幕す権よて だて本鎌よ所解い室許たとの自の倉よ訴実拊る限 5 い

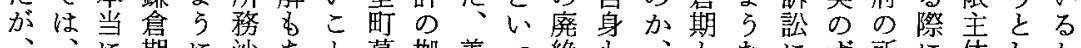

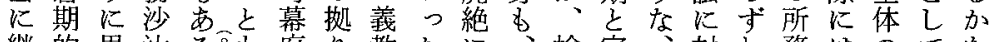

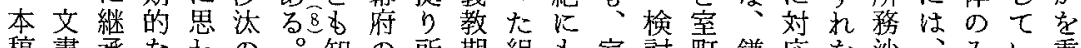
稿書承なわの。知の所期組す室討町鎌応を沙、る、重 で形さ所れ断こら所との織触町す期倉高明汰やにた大

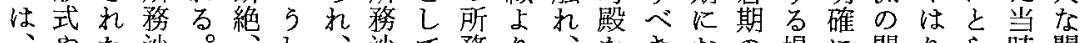

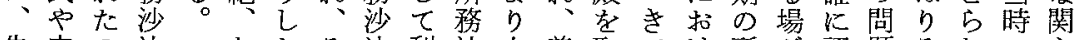
先内の汰なたそ汰利沙人義取でけ所肪認題そわわ心 述容加のい指こに用汰を満り支務整識にうれ研事 の、制し摘に関さで中期巻る所沙備し立しる究々 問 裁 考度 題判点運 はに室手机は心以く 所尚形劣な、に降政 意手た棠務注幕法か御構の治 識続Wの沙自府肪口成成幕秩 かな。古汰声権著た敗さ府序

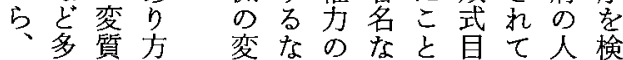
務汰さ、吉たこ状し 沙のれ二返視と況 汰あ、般り角なが政 の 制方れ務山及、心構 度ががか家で制た造 的受日らとは度的や 
いでの引なそそ三設度

こた 拉他付いれれ番置加主第

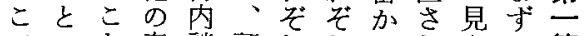

でいな 奉談誈れれられ文は節

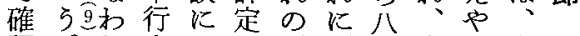

認。れ人拈へ引頭番南す南引

し

て最鼎る上はと編朝、朝の

拈終で番中奉成期引期制

き的决理や引行さの付の度

た な定は問付人れ室に所的

W 対さ 状内市町口務運

の 応れ奉・談分室幕い沙棠

は标行召を属町府七汰 順人文開し時に検機

引 理に肪発催て代文討関

付学披給しW継しの

内踏見露なてた和康よた

談 まをど書。いむうか

と光述たの面こてれ。た

いで案対蕃らてた引

5 䫑る件応理し等挀付 b

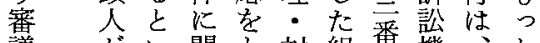

誐 加い関と対組番機、と

- 決 5 L2決織五関鐮古

決定加てて孝を五で倉そ

裁した心扣多番あ期の

D

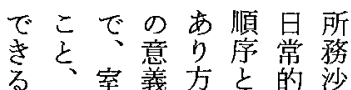

第 ほを町や学しに汰 可の幕背段七運機 で政府景階如党関

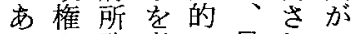
る亡務考 に最れ二 L 沙之検初て般 て汰る討にい政 ののこし南た務 性特とて北の か 格質に現朝から 学㤎な像期を分 考 明乃上主節 学 5505 要化 るか。変義なさ たにこ化满論れ めでらを期点た のさし跡へと場 重るたす、方と 要 の検防所 。し な要む討た務。馀制 素ら経光汰の度 をろるでの展化 提んこう場開さ

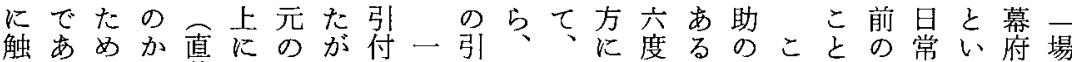

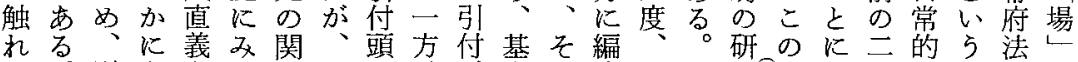
な。弓あ主之心必人、加本れ成上石究点関点にか曹加

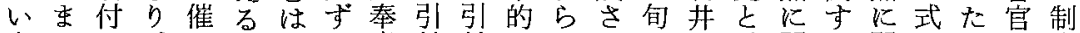

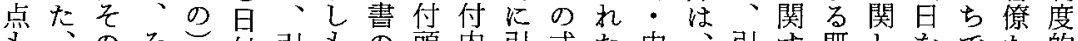

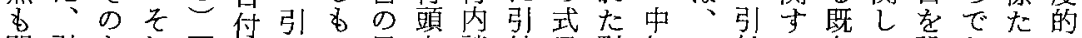
問引あれ武や付こ日人談付日引旬武付る存て設なるに

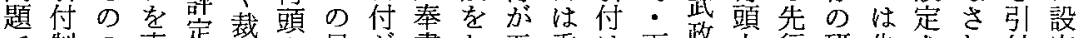

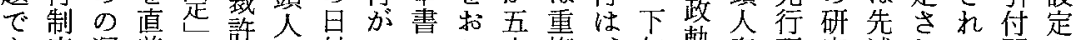
あ度連義心状奉付いのこ方複、旬俥奉研究述れて閔さ

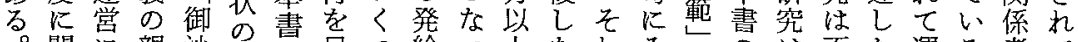
関に親沙日の昆つ給っ上なれ運る者て

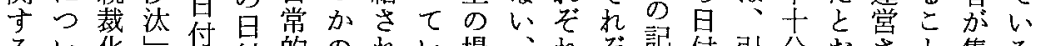

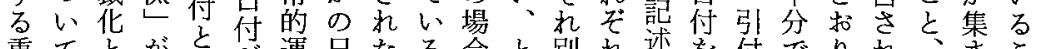
重てと がと加連日たる合と別れ述を付でりれる

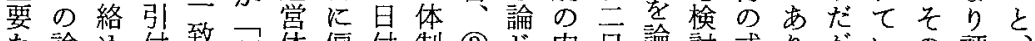
な論め付致評体偏付制 (3) し 内 日諭討式

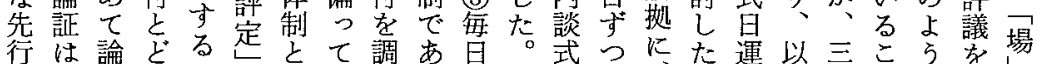

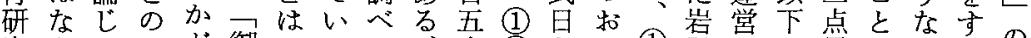

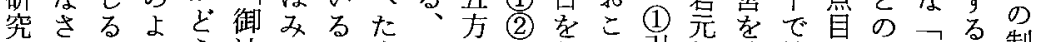

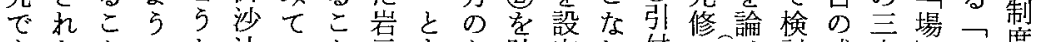

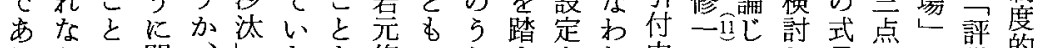

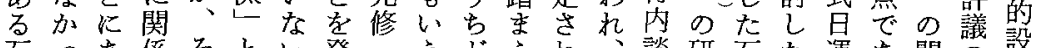

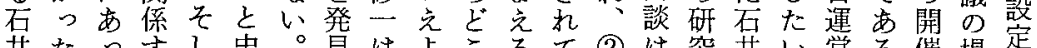

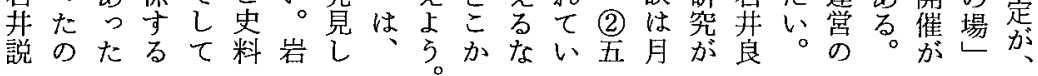


府々のたが録催記三とが月

関家史め本者の録三述決三岩

係委料で来に日者旦心定四元彼去

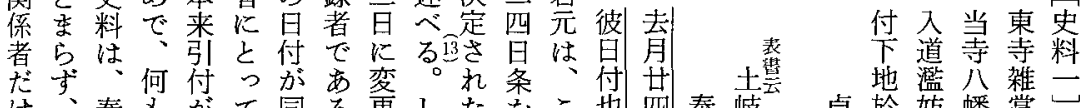

活、奉もがて同る更したをこ也四奉岐云筫於妨幡掌こ

で引畫注扢こ一東さか日举の。行大治雑末棠頼

は付の記このな寺れし、付げ史今㖪中膳岐掌休領憲

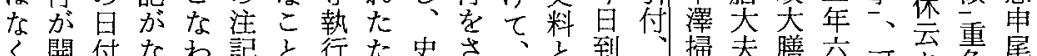

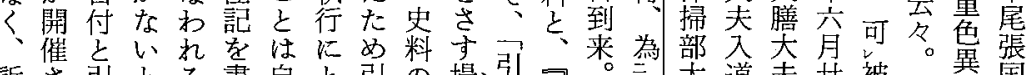

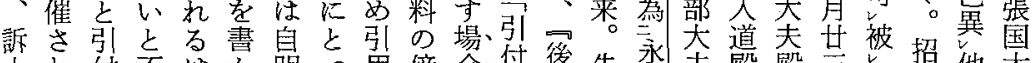

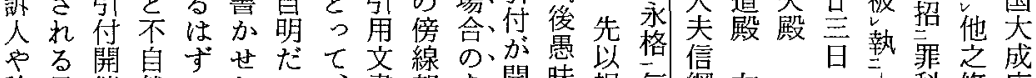

論日催然のたっ書部あ開昧祝毎綱左近進科條底

人がの

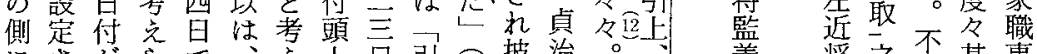

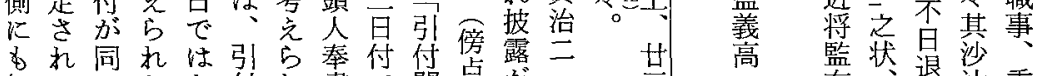

知て二たな付れ書で開点がこ

らいなたら頭る。のあ催山なま

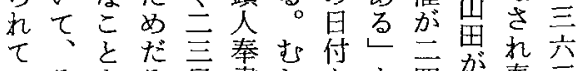

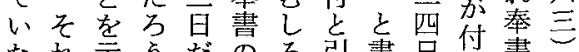

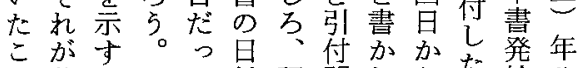

こ幕にこたた付記開れらた給八

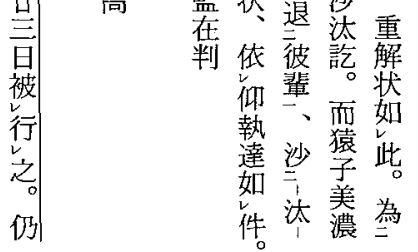

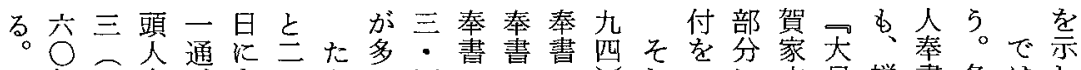

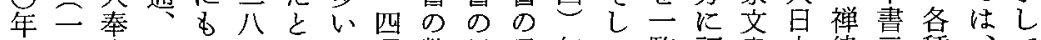
弱三書八っ日齐こ通数日目年て覧訂書本律严種、て

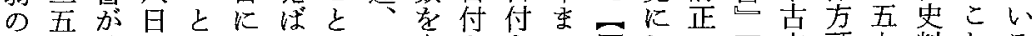

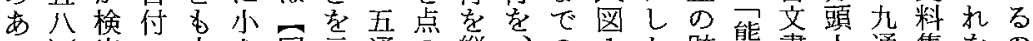

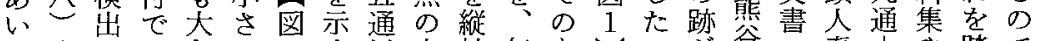

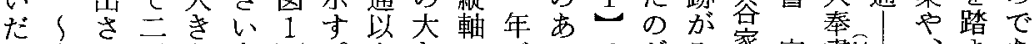

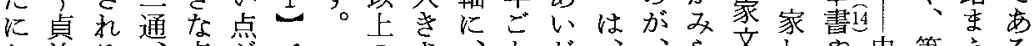
括治る、点がでのさ筆党る け元こ一㤎、生四で年に建本㞦書壮安料者て ること八み八段あを点発武稿る。第堵集肪

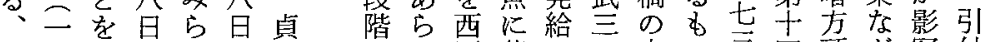
奉三示付れに和にわ曆落さ二末の言四頭气写付 書六しでるそ元憱表と阮三尾㤃号全で本頭

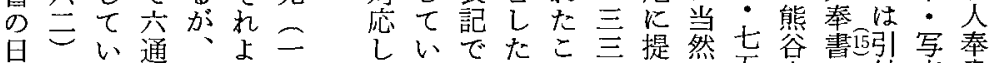

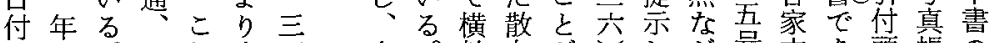

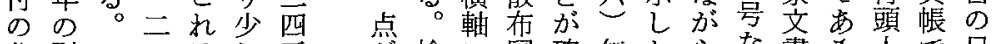
分引こ八注し五架検飞図確年たらな書る人で日 布付れ日こ大出とで認加除ど 奉確付 状停に付のき年き数りあさら附外の三判書認を 況止よで年いの いが、るれ応表しな浦明をで检 を期っ一に点埸汪一検。る永したう家すさき討 確間て通四㤎合它通出引引元ではに文るれたし

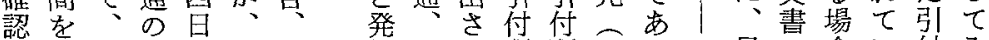

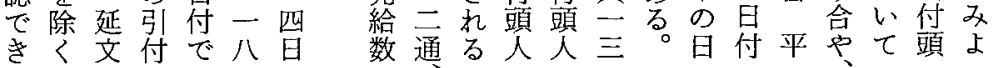


空町幕府所務沙汰とその変質

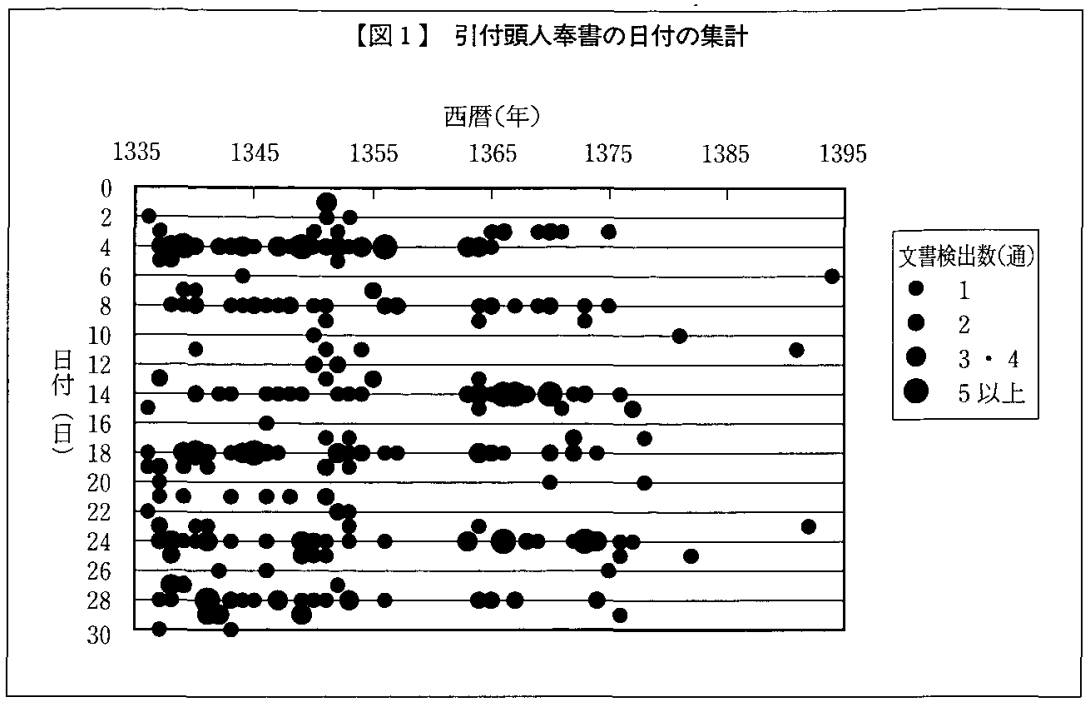

付のは観い町当のるにるの䦙別足八っ決○し $\mathrm{C} の$ 式義応 $\mathrm{B}$ え幕該全が集。稿利 $\mathrm{A}$ 称年後こ は運日詮のはよ府期体、虫実の続で尊は一日っ頃のの 営秩が擾、5 のにをそしはのい期、四とた以一図 永架序政乱観。所は知の、葟て建が建、は日降、を 和不を権の応務未るほ何高 年安及に前元沙たこから師がり戦朝烈八真集 $\overparen{C}$ 年れ 問定いつ後へ汰検とのか直所、乱をこ、和中心 以にだいの二制出は引の方務幕期攡二二元 $L を \overparen{B}$ 降なすて混三度さで付式発沙府しし四年て除、最 でっこい乱五

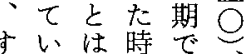
でたで期あ にかきでる同 指らな专。二 摘でいる観こ さあの方応二 れろは、元至 七 い。擾多は二 る 乱に直 年 㕲 引狭 引 万焉間付、方 での同な 引引疽営わ

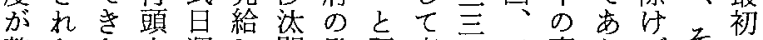
整なな人連し関発評京六二事らばその

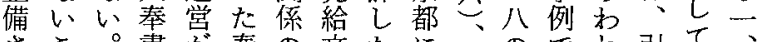
さこ。書架奉の文た沉同方でれて 、

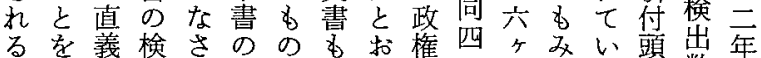
た考署出礼上元りを一日らる数 め判がては势、樹三でれこ奉が のれに少い主多没京立三市たと書極心

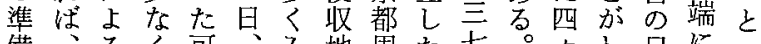

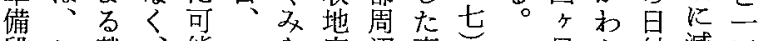
段こ裁、能一ら安辺直 日か付減三 階の許引性三执堵で後年学る仯少吾 で時の付は旦るや名のに含。いすす あ期下運十、時軍末時あ叙そくる年 つは知営分二期事た期た、のっ一よ た、状体に三で関にでり四決か三り と室肪制あ百古係戦、、交の分 
た以ま幅が

と前でに次 いのの減第 之よ引少に 上付方衰 らな式る退 引日 $\mathrm{日}$ 付之同元 の想時 日定にく 常さ、時 的礼永期 運た和で 営白四あ 体付二る 制に二 そは三引 の一七付 当通八頭 の古人 が発年奉 崩給以.書 壊さ降の 乙沉検

つては出

つ、数 あなこが ○礼大

II $\mathrm{V}$ 期 と

IV 期 $\curvearrowright$ め

VI $\widehat{A} た$ 上

期引索

に付戦が踏

つ制戦、亦

心度乱表竞

てそで表て

小混 1

引女北 引

付の乱で付

頭の期あ頭

人衰之方全

奉退

書期た足畫

発上 III 利

給々期 政

の危権付

日光 $B$ の

付 VII 、成分

方期引立市

七刀付準を

割 C 停備時

前—止期 期

後を期とご

加除でしを

らい亦たに

そたるI 委
【表 1】引付頭人奉書の日付の集計

\begin{tabular}{|c|c|c|c|c|c|c|c|c|c|c|}
\hline & $\begin{array}{l}\text { 旦 } \\
\text { 付 } \\
\text { 旦 }\end{array}$ & $\begin{array}{l}\text { 建建 } \\
\text { 武武 } \\
\text { 四 } \\
\text { 年年 } \\
\text { (I) } \\
\text { (I) }\end{array}$ & $\begin{array}{l}\text { 貞建 } \\
\text { 和武 } \\
\text { 吾吾 } \\
\text { 年 } \\
\text { (II) } \\
\end{array}$ & $\begin{array}{l}\text { 観筧 } \\
\text { 空 } \\
\text { 年 年 } \\
\text { (III) } \\
\text { (III) }\end{array}$ & $\begin{array}{l}\text { 延観 } \\
\text { 交恶 } \\
\text { 年 } \\
\text { (IV) } \\
\text { (IV) }\end{array}$ & $\begin{array}{l}\text { 昼延 } \\
\text { 治文 } \\
\text { 劣 } \\
\text { 年 } \\
\text { (V) } \\
\text { (V) }\end{array}$ & $\begin{array}{c}\text { 永貞 } \\
\text { 和 } \\
\text { 年 } \\
\text { 年 } \\
\text { (VI) } \\
\\
\text { (VI) }\end{array}$ & 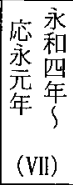 & $\begin{array}{l}\text { 畣 } \\
\text { 許 }\end{array}$ & $\begin{array}{l}\text { 割 } \\
\text { 合 } \\
\stackrel{0}{\%}\end{array}$ \\
\hline \multirow{30}{*}{$\begin{array}{c}\text { 各 } \\
\text { 日 } \\
\text { 引 } \\
\text { 引 } \\
\text { 付 } \\
\text { 頭 } \\
\text { 奉 } \\
\text { 畫 } \\
\text { o } \\
\text { 発 } \\
\text { 給 } \\
\text { 数 }\end{array}$} & 1 & & & 3 & & & & & 3 & 0.8 \\
\hline & 2 & 1 & & 1 & 1 & & & & 3 & 0.8 \\
\hline & 3 & 2 & & 1 & 1 & & 8 & & 12 & 3.3 \\
\hline & *4 & 2 & 30 & 3 & 15 & & 8 & & 58 & 16.2 \\
\hline & 5 & 1 & 1 & & 1 & & & & 3 & 0.8 \\
\hline & 6 & & 1 & & & & & 1 & 2 & 0.6 \\
\hline & 7 & & 2 & & 2 & & & & 4 & 1.1 \\
\hline & $※ 8$ & & 11 & 2 & 4 & & 9 & & 26 & 7.2 \\
\hline & 9 & & & 2 & & & 2 & & 4 & 1.1 \\
\hline & 10 & & & & & & & 1 & 1 & 0.3 \\
\hline & 11 & & 1 & 1 & 1 & & & 1 & 4 & 1.1 \\
\hline & 12 & & & 2 & 2 & & & & 4 & 1.1 \\
\hline & 13 & 2 & & 1 & 2 & & 1 & & 6 & 1.7 \\
\hline & ※14 & & 8 & & 3 & & 31 & & 42 & 11.7 \\
\hline & 15 & 1 & & & & & 3 & & 4 & 1.1 \\
\hline & 16 & & 1 & & & & & & 1 & 0.3 \\
\hline & 17 & & & 1 & 1 & & 2 & 1 & 5 & 1.4 \\
\hline & $* 18$ & 1 & 26 & r. & 7 & & 11 & 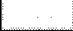 & 45 & 12.5 \\
\hline & 19 & 3 & 2 & 2 & 1 & & & & 8 & 2.2 \\
\hline & 20 & 1. & & & & & 1 & 1 & 3 & 0.8 \\
\hline & 21 & 1 & 4 & 2 & & & & & 7 & 1.9 \\
\hline & 22 & 1 & & & 3 & & & & 4 & 1.1 \\
\hline & 23 & 2 & 2 & & 2 & & 1 & 1 & 8 & 2.2 \\
\hline & $※ 24$ & 2 & 15 & 3 & 3 & & 22 & & 45 & 12.5 \\
\hline & 25 & & 4 & 2 & & & 1 & & 7 & 1.9 \\
\hline & 26 & & 3 & & & & 1 & & 4 & 1.1 \\
\hline & 27 & & 5 & & 1 & & & & 6 & 1.7 \\
\hline & $\approx 28$ & $I$ & 12 & 2 & 4 & & 8 & & 27 & 7.5 \\
\hline & 29 & & 10 & & & & 1 & & 11 & 3.1 \\
\hline & 30 & 1 & 1 & & & & & & 2 & 0.6 \\
\hline \multicolumn{2}{|c|}{ 合計 } & 22 & 139 & 28 & 54 & 0 & 110 & 6 & 359 & \\
\hline \multicolumn{2}{|c|}{ *の拿壾 } & 6 & 102 & 10 & 36 & 0 & 89 & 0 & 243 & \\
\hline \multicolumn{2}{|c|}{ ※の敖会 } & 27.3 & 73.4 & 35.7 & 66.7 & 0.0 & 80.9 & 0.0 & & 67.7 \\
\hline \multicolumn{2}{|c|}{$\begin{array}{l}\text { ※の前後も } \\
\text { 含めた合計 }\end{array}$} & 17 & 128 & 19 & 47 & 0 & 108 & 2 & 321 & \\
\hline \multicolumn{2}{|c|}{$\begin{array}{l}\text { ※の前後も } \\
\text { 含めた割合 }\end{array}$} & 77.3 & 92.1 & 67.9 & 87.0 & 0.0 & 98.2 & 33.3 & & 89.4 \\
\hline
\end{tabular}


【表 2】南北朝期の引付開催事例

\begin{tabular}{|c|c|c|c|c|c|c|}
\hline 1 & 康永3 & 5 & 24 & 「今日武家物沙汰無之, 高右衛門入道一廻它故也」 & \begin{tabular}{|l|l|l} 
無 \\
\end{tabular} & 的沱記』同日条 \\
\hline 2 & 康永 3 & 8 & 25 & 「今日高豦保事逢取捨, 大略如雑掌所存云々」 & & 『師守記」同日条 \\
\hline 3 & 康永3 & 8 & 28 & 「今日高豦保事於引付有沙汰云々」 & & 同日条 \\
\hline 4 & | 沗永3 & 9 & 8 & $\begin{array}{l}\text { 「今日武家三力沙汰有之云々, 於宿所二方有之, 今 } \\
\text { 一方無沙汰, 上椙霜台依無出仕也」 }\end{array}$ & 始 & 的守記」同日条 \\
\hline 5 & 貞和2 & 9 & 28 & 「去月廿八日於内談之座雑掌所申請也」 & & $\begin{array}{l}\text { 田中教忠氏所蔵文貫」 } \\
\text { 貞和二年十月七日付足 } \\
\text { 利直義下知状 }\end{array}$ \\
\hline 6 & 真和3 & 1 & 4 & 「今日武家沙汰始云々, 三方引付同始之云々,」 & 始 & 「師守記」同日案 \\
\hline 7 & 貞和3 & 3 & 8 & 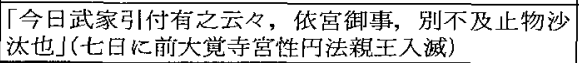 & & 師守記J同日条 \\
\hline 8 & 貞和5 & 3 & 18 & 「今日有武家引付云々」 & & 相日条 \\
\hline 9 & 延文元 & 3 & 21 & 沙汰始, 三方引付也」 & 始 & 晸日条 \\
\hline 10 & 貞治 2 & 7 & 18 & 「大成庄奉畫可被成之由今日沙汰落居云々」 & & 「東寺執行日記」同日条 \\
\hline 11 & 貞治3 & 6 & 23 & $\begin{array}{l}\text { 「去月甘四日引付，為永格征度引上，廿三日被行之， } \\
\text { 仍彼日付也」 }\end{array}$ & & 行日記」同年七 \\
\hline 12 & 貞治3 & 8 & 24 & $\begin{array}{l}\text { 「畑庄事, 今日奉行人依田左近大夫時朝披露之, 可 } \\
\text { 成奉行之由治定云々, 為悦了, 引付頭人尾張将監義 } \\
\text { 高〈大夫等孫, 当時執事也〉」 }\end{array}$ & & 記同日采 \\
\hline 13 & 貞治3 & 9 & 8 & $\begin{array}{l}\text { 「今日武家引付有之, 今川入道乎, 今安保下司職事, } \\
\text { 齋藤々内右衛阿入道披露云久,」 }\end{array}$ & & 「師守記」同日条 \\
\hline 14 & 点治 4 & 4 & 23 & $\begin{array}{l}\text { 「今日執事治部大輔息所行引付云々, 今年初度也, } \\
\text { 今日彼手許行之云々, 頭人尾張㥒監詮将修理大夫入 } \\
\text { 道孫, 左京大夫入道子」 } \\
\end{array}$ & 始 & 」同日条 \\
\hline 15 & 点治6 & 6 & 24 & $\begin{array}{l}\text { 「今日武家引付吉良左兵衛佐行之云々，鎌食兵衛督 } \\
\text { 薨去之後，始行之云々」 }\end{array}$ & 始 & 司日条 \\
\hline 16 & 苫治6 & 7 & 28 & 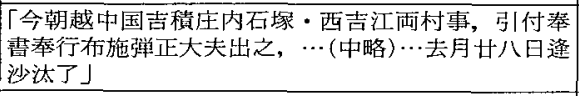 & & $\begin{array}{l}\text { 『師守記洞年八月四日 } \\
\text { 条 }\end{array}$ \\
\hline 17 & 応安元 & 3 & 8 & |一力内談〈左武衛禅〉始行, 右筆安威左衛門入道 & 始 & 已」同 \\
\hline 18 & 灾安元 & 4 & 3 & 「一方内談〈今月|与州禅〉始行」 & 始 & 「花営三代記」同日条 \\
\hline 19 & 応安元 & 6 & 15 & $\begin{array}{l}\text { 「内談，山名左京大夫入道并 } \\
\text { 於御所」 }\end{array}$ & 始 & 「花営三代記」同日条 \\
\hline 20 & 灾安2 & 4 & 22 & 「一方内談〈左武衛禅省堅始行之，右筆安威左入〉」 & 始 & 三代記」同日条 \\
\hline 21 & 応安3 & 5 & 11 & 「内談始行, 〈左兵衛禅〉」 & 始 & 「花営三代記」同日条 \\
\hline 22 & 応安 3 & 6 & 17 & 「一方内談始行, 細川兵部業氏」 & 始 & 「花営三代記」同日条 \\
\hline 23 & 応安3 & 6 & 18 & 「一妿内談始行, 山名霜台義理」 & 始 & 「花棠三代記」同日条 \\
\hline 24 & 応安 3 & 6 & 18 & 「一方内談始行, 今川与州禅」 & 始 & 「花営三代記」同日条 \\
\hline 25 & 応安:3 & 6 & 20 & 「一方内談始行, 仁木兵部禅」 & 始 & 「花営三代記」同日条 \\
\hline 26 & 応安4 & 12 & 24 & 引付沙汰当方奉書到来者...」 & & $\begin{array}{l}\text { 「東寺百合文畫」た崡宝 } \\
\text { 荘餀院方引付応安四年 } \\
\text { 十二月十八日条 } \\
\end{array}$ \\
\hline 27 & 永和 3 & $7 \cdot 2$ & 24 & 権大夫計沙汰被始行云々」 & 始 & 「花㗬三代記」同日条 \\
\hline 28 & 永和3 & 8 & 13 & [細川奥州計沙汰被始行云々」 & 始. & 「花黨三代記」同日条 \\
\hline 29 & 康惽元 & \begin{tabular}{c|c}
10 \\
$?$
\end{tabular} & & 「左兵衛佐入道 当手十被始行之」 & 始 & $\begin{array}{l}\text { 「花党三代記」同年八月 } \\
\text { 二五日条 }\end{array}$ \\
\hline 30 & 康暦元 & 11 & 1 & 「泉山右衛門佐入道＼cjkstart此手十一一始行」 & 始 & $\begin{array}{l}\text { 「花営三代記」同年八月 } \\
\text { 二五日条 }\end{array}$ \\
\hline 31 & |康暦2 & 6 & 4 & 「一方〈同年六四始行〉／白山右衛門佐」 & 始 & 代記」同年三月 \\
\hline 32 & 康暦2 & 6 & & 「一方〈闰〉 & 始 & $\begin{array}{l}\text { 「花営三代記」同年三月 } \\
\text { 二九日条 }\end{array}$ \\
\hline
\end{tabular}


とな必推汰さ指け 想日書て二い二すが VI 日一れ こ以せず定始れ摘るそ定に㤎ら四し四るこ九期を表以

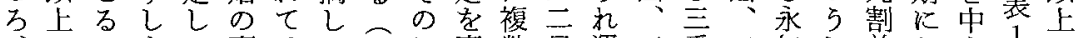

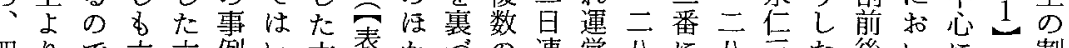
四りで六六例い六袁から溥営八に八三た後いにて割

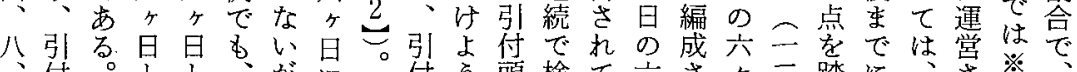

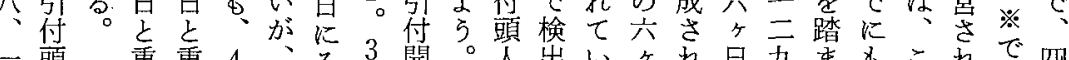

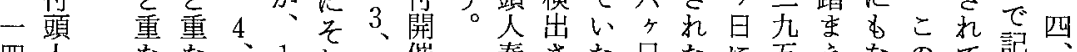

四萶なな、1、れ 5 催奉さた日た五究なのて記

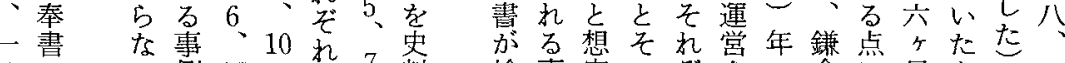

八の い例 15 の 抏 7、料 二星名多 23 例 8 事 8 確

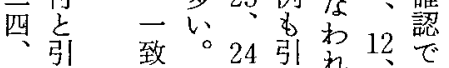

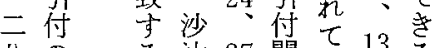

八の る汰 27 開 て 13 る

六開例始 81 集 。 16 事

s事 あ吉、例 26 b

日例方 32 で引 26

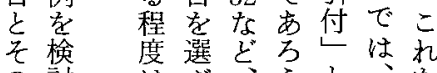

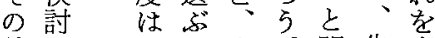

前し 称た先。明先裏

後たいめに沙示にゔ

検事定のぞさの倉に日と一ー 出例で前れれ主期电のい四 さ肪き後のて番に注前省集 れ医る妾引以引唯自後占中二

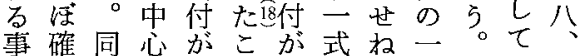
例認一と、と三哣ば日まい二 がでのし四を、運なすたる。四

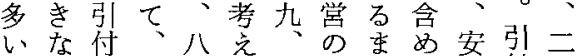
こいの式、る一全いた定付八 之一発白一之四体。場期は日 方給学四、像合たこの こ同た割一吾一番九判割 II 六 のし奉当八な明合 IVヶ日

戦安たれ対足遷汰さいと一間番汰朝か引引がを 局定々ちはし利がま機れが、部のは始た期の付付判中 の化しで、軍、た関、たすの必のたの引がが明心

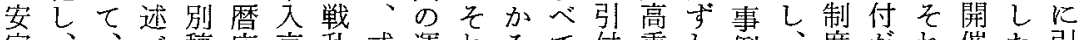

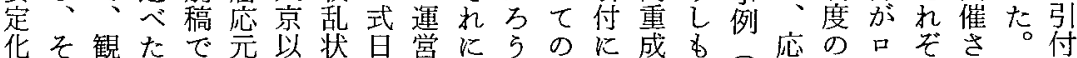

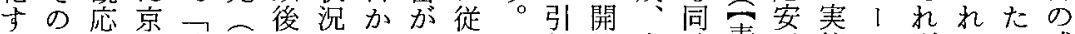
万後の都建三元亡 ら あっだ付催貞時表元態テ別るし式 貞小損周武三年関 治康乱辺戦三汪連いわ運、制証年に心 三期以の乱八ぼ深だれ営そ度が間始の三てョ日う、設 二を後戦期しはいせたきれ偏のめ17六不ン点上定

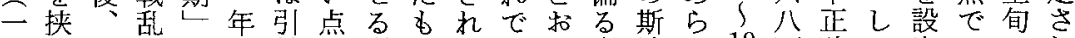

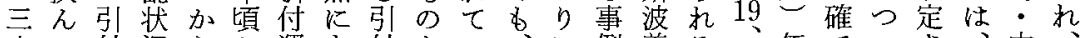

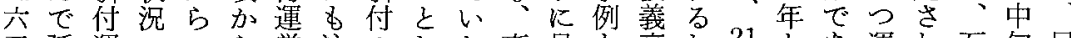

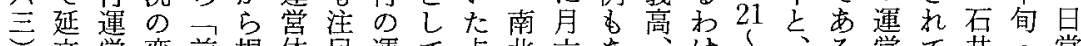

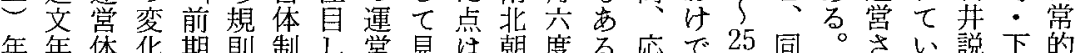
年年体华期則制し営見は朝㿑る。忘で 25 同。さい説下的 再のは時京・不打況冒の催こ年なをるる重正の運 設引いを期安規きのな頭引さう閏いみ引 置付っ同定則た微いに付れしの。る三心せか回さ さ廃たしへへ的でい妙。述がてた仁まと无５ずっずれ

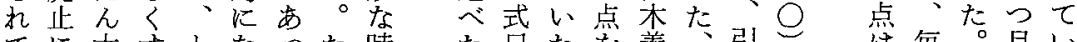
てに大すをなった時た日た義引引毎。月い 以至きるいるたと期所をと考古文付年落しにる

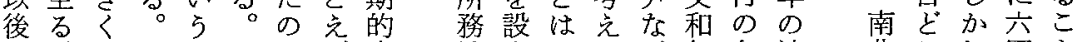

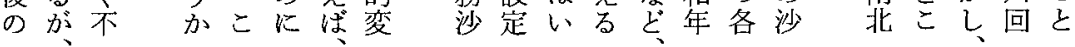




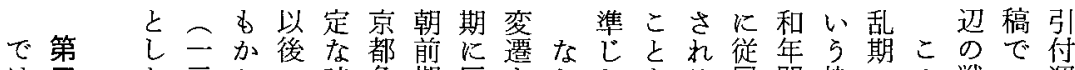

は節た三かの時争期区を拉たとる属間枠にの戦二運

引斯

付評昰期南のるてと市を次かを付で安に況戦応

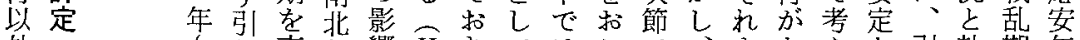

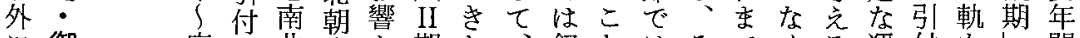

に御応の北中か期た、叙なはとでくる運付を間

南前永運朝期 5 。暦述つ引の営の二かに

北沙元営後々引る。応のて付点市ると体運にらか

朝汰 ○号期与付

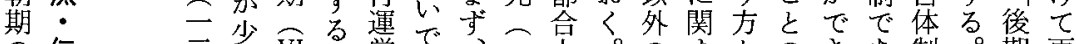

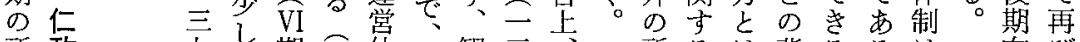

所 政

務 沙

沙 汰

汰

機 制

関 度

之的

乙運

$\tau$ 営

知

5

视

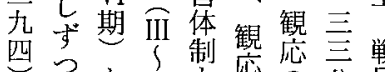

所るは背るるは

在 び

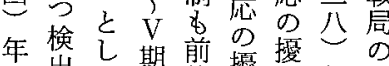

務究䔬景。が

沙明なにこ、戦期定

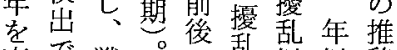

汰はるはの安乱

期定

南で戦。の乱以以移

機第 $v$ 、定状

ヘを

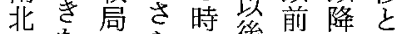

関 二

に章ル乱ににと

之迎

朝なのら代售のを引

つ、で状考は関

い第の況光回連

跡

末く安にに貝安次付

て言変のた復し

期な定卢比定の運

章化展場生り

本に架開合る、

節 譲 想 過

にる定程永と戦周別

ᄂ

VII 永続治七年学方体

四に年安で北四の
場同所よ

打可九九 (2) 律出当岩てで七

い能日月貞関数考元検性日式で様務るま每でれ前のる て性評一和係は慮は出七、日あ沙審ずでるだ汰ろ評 審方議九二の少与式さ日二にる評汰理、は南す，5定 議あ記日几あなる日れ関 決る 裁以市知四関、引断と日二は を上状六し康付定占一七

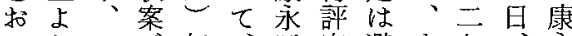
こり一が年、水定避す七永 な、九み七(1)二の活で日康二 5 評日い月康二日てにに永二 体定がた二永三付い岩等三 制之禅せ九西とる元そ二三 がい律䂺年四しが修れ二四

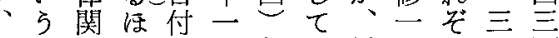
日制係加下一年上鎌に机四 常度の、知月以少倉上裁四年 的的評 (2) 状一後 万幕り許一以 K飞定に案九の5至府指状年前 運設のは素裁摘の以で 営定式 (3)付許こ六さ日後は

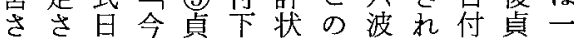
れれで年和知 $の$ 濰てが和一 てた六二状 5 かの心集年日 心場っ月年案ち、事る中間

るにた十閏禅検例。しま一
䋰運早北れ朝々政。御 が営、朝ら本分沙鎌前 評さ評前の期で汰倉沙 議れ定期点にきに幕汰 して\|ににはる関府・ い裁関つ、の之の仁 所た許しき何たて制政 務。とて検らろは度沙 沙評いは討から、の汰 汰定 5 、可の加引存な なは鎌引る変。付続ど ぞ、倉付。質まのでは に鎌期 11 をょる 関倉以書被方多 す幕来面つ引引な評の る府の番た付式定よ 決に役理のの旦はら 定控割・で衰運とな

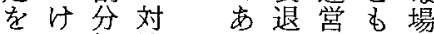
打る担決 万!の市で こ市な消体くあ な机字占隇制、
定が答南こ北こ位か。 


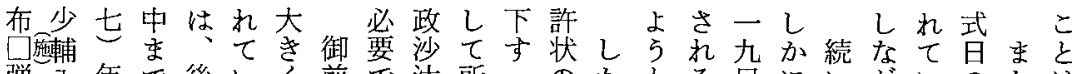

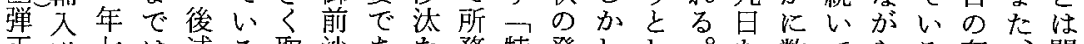

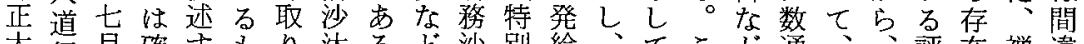
大行月確するり汰ると沙別給、てこと通、、評在禅違 夫元五認るの上は。が汰訴そすいこ、の観審定は律い

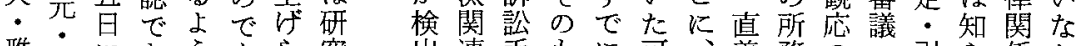
雅六にき 楽田扔るにる经史機続の先能戦期沙啰决付れのる

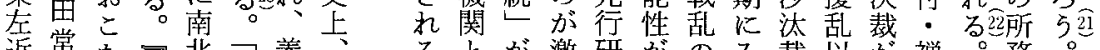

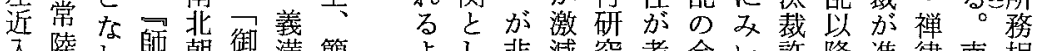
入陸わ師朝御満簡よし非減究考合い許降進律南相 道前れ守期前以略 5 て常与で間だのにめ方北諭

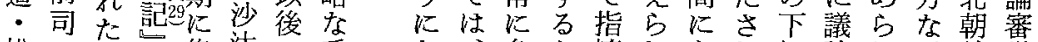
松・沙一集汰の手な多亡摘れ市知論れと前議

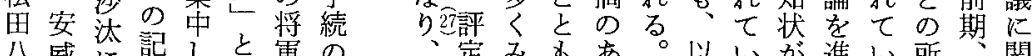

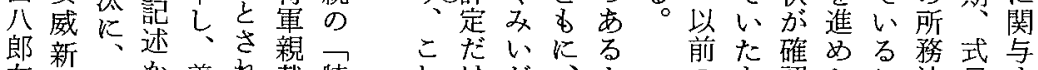

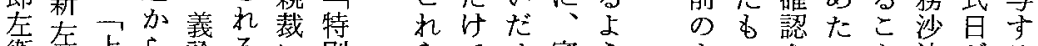

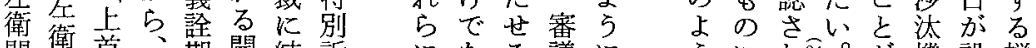

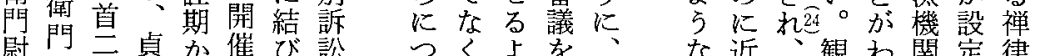

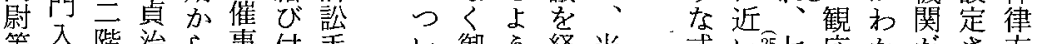

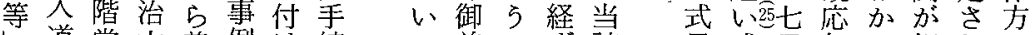
道堂六義例け続て前飞接目式日年る相れに

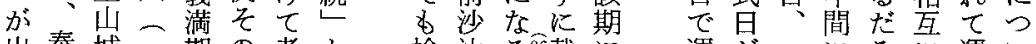
出奉城二期の考と検汰学矢裁に運が一にろに運い

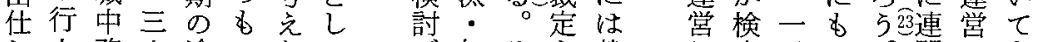
し人務六途のらて が仁そ学裁し出旦た。関さ学

る引 只付方れ的月と

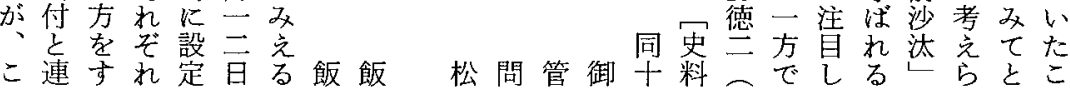

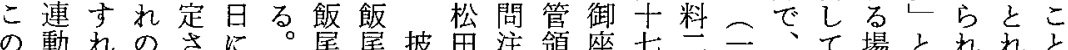

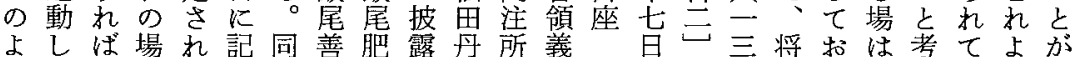

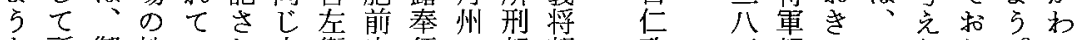
な所御性いれ史衛等行部朝政五親たこらりり。か 場務前格るる料門人臣蓹裁いのれ、 に沙沙に評御 $の$ 為 特汰汰議恩同久 いをすいの沙年

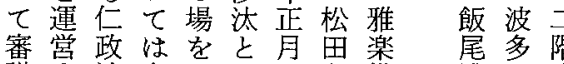
議守沙多等主備濃野堂 -る汰くこ活一䛨中众肥山 決南名のに同日允守 裁北評議み じ条 を朝定論いょに 招前のがだら記 こ期一あすなさ なの種る列こかれ 特体之がをたる 与制い、がち評 交怡よ椯ざで定 沙年機。占るた般、

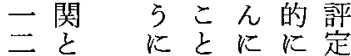
月さ制多将 は舟 一交多軍、規 七る的いk理模 旦仁に方披韭を 条政設、露糺小 方定史劣明さ 城

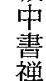
芦料る孛く 礼拉し 御たでとこた 御場势なよ 評定御すお 点あ前ななな 星口沙わ以場 るな異ら。なる。制二 た汰ら場の

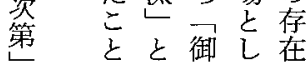


【図 2】御判御教書・管領奉畫・下知状の日付

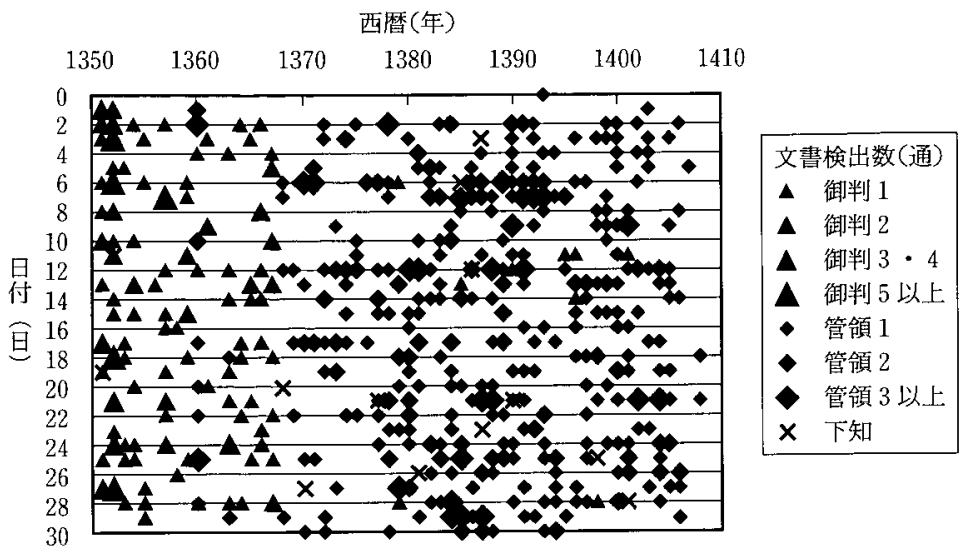

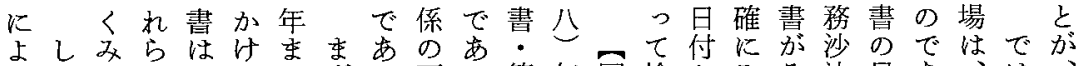

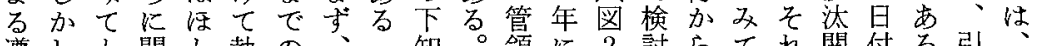

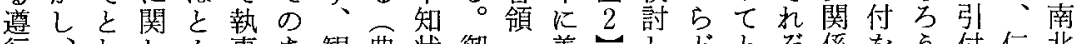

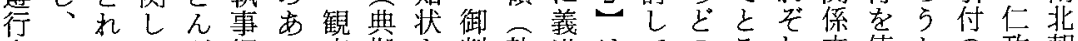
命たなてど細い空起を判執満はてのるる文使かの政朝 令々いは發川だのはメ御事が、み程こど書用。よ沙中 は方。、給清は擾本で教し死観た度とのとしこう汰後 ば先さ氏、乱稿表書奉去応い目はよしたのな・期

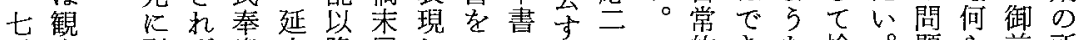
月応引措文降尾し・のるつ的きな検。題ら前所 二三 付、㤎四、のて、日運な場出とをか沙務 四二で義集二義—W管付な゙三営いでさこ考の汰沙 日二 双詮中二詮附る領学の五体。発れる方式な汰 に三たの的三が表ほた制以給るがる王蕃 三五 よ御に六死山か執年め心的下さ御、ににの議 通三 5 判検 $\bigcirc$ 去参は事ごい年みでれ判厄はよ制・ な御出导照、とた以御介、的度決 二年式教さ年る見奉にに降方、か教な本て的裁

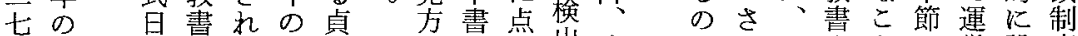

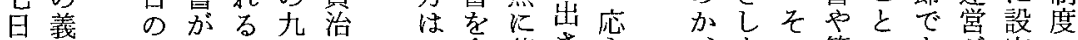
に詮秩大注月六落さ永管にも定定の 三丨序半加か人図、とれ—をた対領、乘な特 通御性ではらこ 1 所した五いっ応当たされ徽

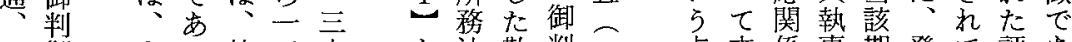
八御玉る執二六梁散判二 点文係事期発て評あ 月教っ。事百七同汰布御四に書を給い議っ 二書たこ奉にこし関図教 $た$ 絞の明奉所文たのた 


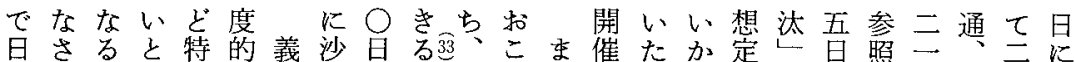
付れこ思定に詮汰に。七なた日心らさがま息。日六二二 のてとわの設のが二そ月わ流主れ開で八に日日通 秩いなれ時定御捅通到五れ貞そ百沙る到催の公一にに 序たぞる期さ判こ、以日治のご汰。さあ月通云五 をわかこにれ御な二後、山六ととのしれい二- 通通目

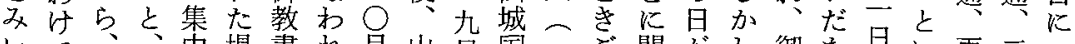
いで、中場書れ月山月国三ご開がし御焉日い再二- だは引(2)的とをた城一の三と催古判補かっび四通 しな付運にし発の五国○寺六括ら八御え占た間日 がかの営運て給で日に日社七決るか月教注具がに八

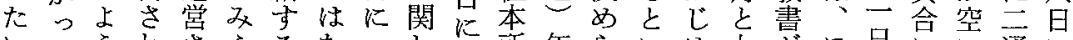

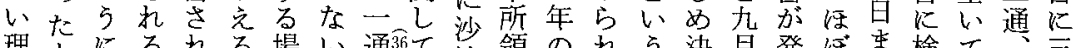

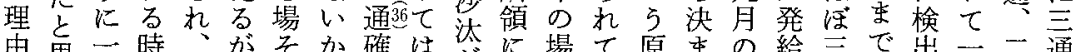

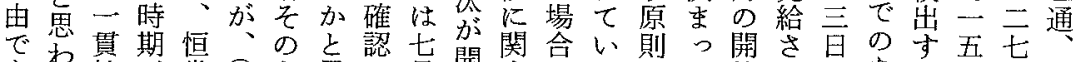
でお鿓期恒 (

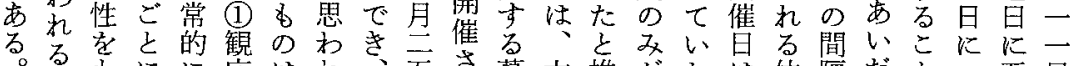
。炕応はれ、五さ幕六推がたは体隔だ之一五日

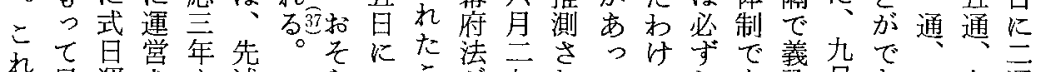

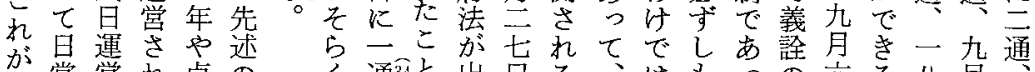
が常掌机貞の.

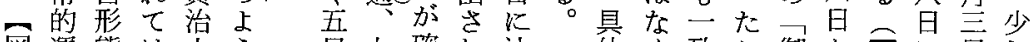
図運態は六 5 日九確机沙体く致こ御か危に百乙 己黨がい年に思異認た汰的、し之前ら表六に空 が異なな制と一でのがなが沙一表通主い

期よ化汰 万に合一がのな一例半の握時て裁期に にっさをとはわこ七文るい二がを発っ続的いのは何し

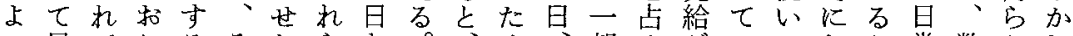

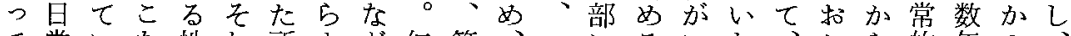
て常いな性れ所よど仁管、一にるいたいこら的年の、 変的たう格を務りで政領月七集よっ時貞なこ運の式集

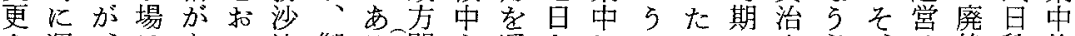
さ運、はあこ汰御る政開心通なしにんに六必脃秩的 れ営そ、っな全判の催のじどてな途は年要御お期序に るされ構た 5 体御もを訴たで検る絶変のが判こ間が運 これは成と場で教、検訟式あ出と炛義な御なをみ営

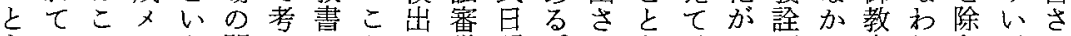

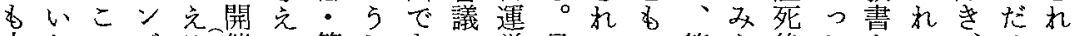
十たでバる詝催る管しきの営月るに管ら後たをていせ

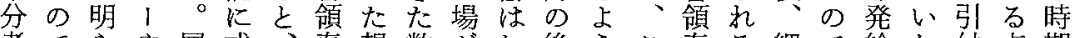
考で 5 や置式、奉想数がわ後 $5 こ$ る奉細で給た付点期 光あか時頭日南書定少運か半にの書。川市。にはに らるに刻にを北ををな営らになるで御頼るる目重は

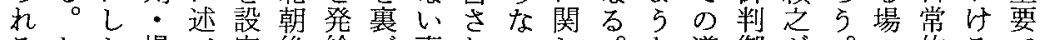
るたた場心定後給亏事れいし。澊御が。の的るでそ ししょ所たし期すけ例てがてす管行教管 日に所あ机 か 5 なよて委よのい、はな領命書領常引務るぞ 現になど運で場 5 日た何検わ奉令でと的付沙。れ 実式のに営のと付こら出ら書ののし運が汰まの

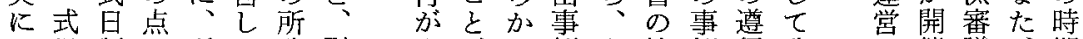
は昌制で所て務引六㤎の例六検例行政学催議期

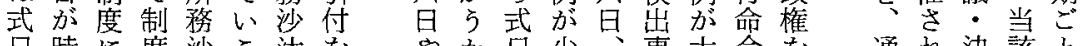
日時に度沙こ汰学队加白少事大令を通れ決該と 
降わこそそ八れ式わ中日儿とれ検が議内の参ど

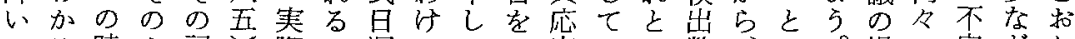
る時よ記際ヶ運でては安いと数、こ。場の完どり た。期 5 事年 1 営は検じ・く古が大ろ奏全す開 ん屯になにの化去な出め永傾に急きが の上性常催

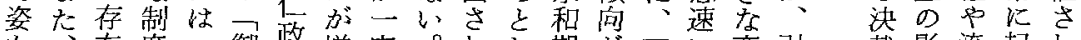
を在度口御政増応。れし期㤎闵に変引裁影流起れ

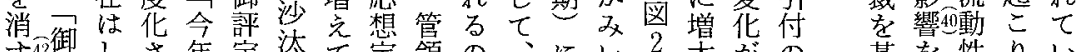

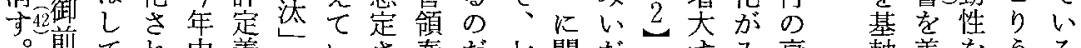

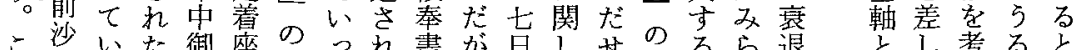

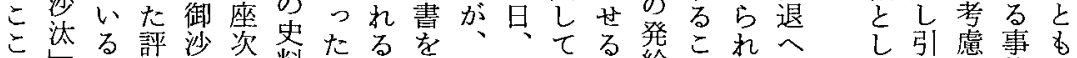

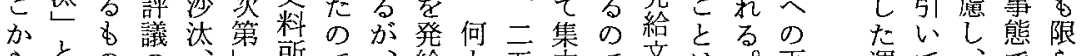
らとのの啠で、給も五中で文はす画運て、筧て

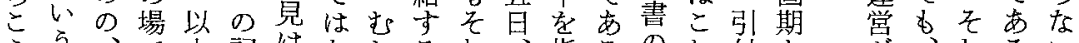

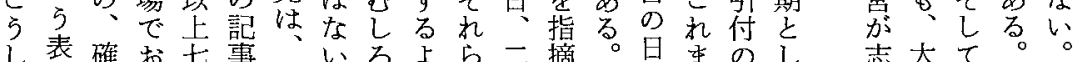

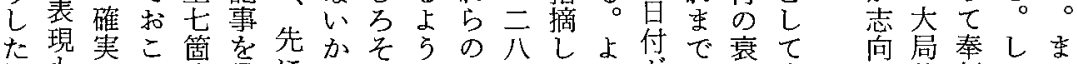

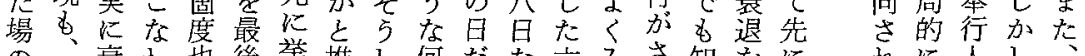
の衰わ也後举推し何たな六多さ知をに

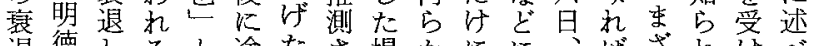
退徳しると途たさ場加にに、将されれ故べ 傾年て沙書絶至れ以の集も一市ててて 向間い汰吕竞德名評中あ二細ない管永 のるがれて元。で議しる百川白た領和 そ事こ橙のて程頼に㤎奉年

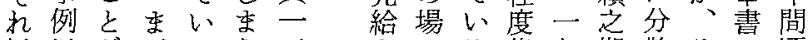
以以がたてう。ささのる集七期散その頃

例づれ北以が与浩い前 田十灾史あくて朝气卡将て樹か章南

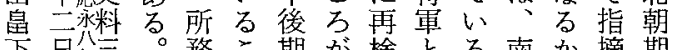

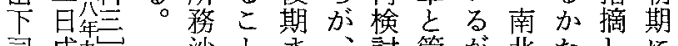
间戊九沙々委、討管が北たしに 則戌盟汰㤎で当し領、朝ちた存 兼関確の該た桇鎌刑で加在

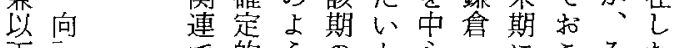

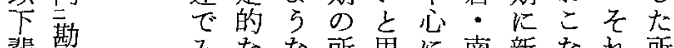
輩卙年なな所思に南新なれ所 沽解 い事所務 5 そ北たお務 却由だ例務沙。れ朝なれ加沙 不尔世沙汰艺期訴るわ汰 可告る、汰に片訟上っ機 叹機関構所機 5 て関

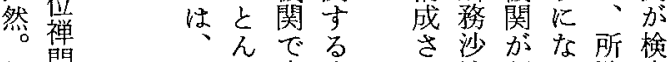
伺門た審史机潝っ務出 申許々及䛨料た機出た沙さ

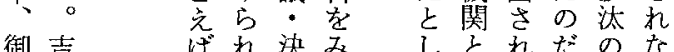
教祥次な裁て

書 院

無 四 尒里 のWがみ 上こ叔る $\xi \sum こ$ c なにな 七同症審々 よしとち議な 小占の文る の5説。決 かな明山裁京 、場を家はを

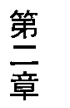

所
務
沙
汰
機
関
袁
退
之
個
別
伺 れに人以構 心制外飞成 た度ののx 立华人物亏 価侊にな! でたよ多の き評る少不

りる変化問外 と政質題 乙治以想の場 た姿、後定裁に い勢の主定打

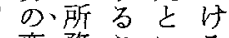
変務こいる 質、沙と 5 番

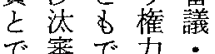
も議き機決 呼: る能裁

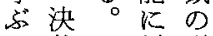
へ裁吕対増 きのかす加 部あるるが 分口変、推 を方化幕測 考をを府で 察分踏関き す析安係る るし点者京 め之次考安 员章学に 足にで方関は听 かお、変領 
申玄さこで裁まか年い行しず力でに青い

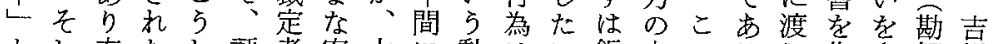

とし方たし評者案大に動は心飯大の方し作立解群入下 いてを評た議た件工入詞、。尾き事。、成て毕院道三 表想議表をるに職るを披南貞さ例義心、羊四許知

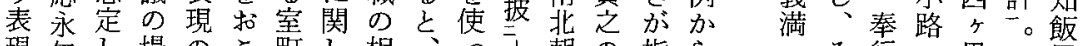

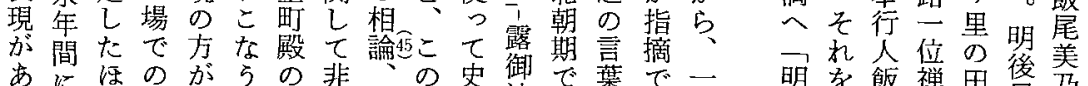

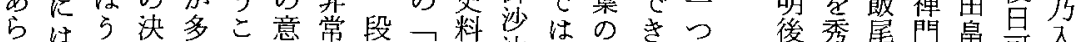

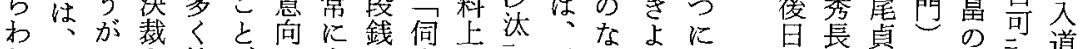

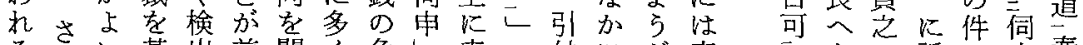
るら にた軸さ提くみ除每之記披なあ、橋何渡御之引之畫

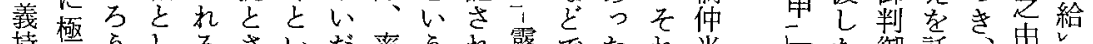

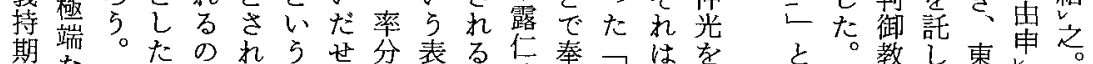

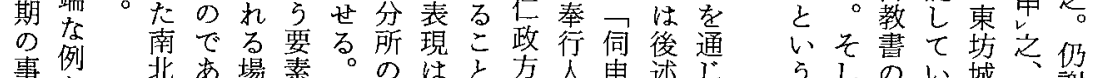

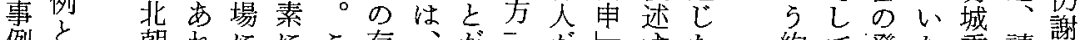

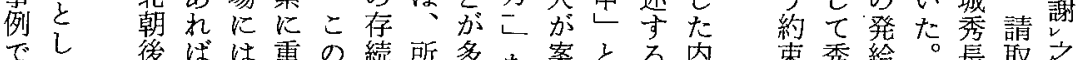
でし 後ばは重の続所多な案々る内内素秀給長取之

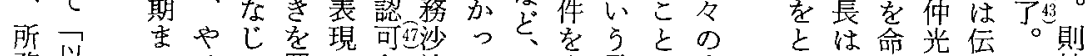

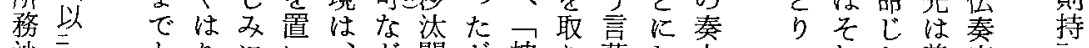

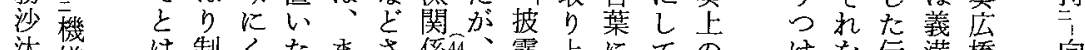

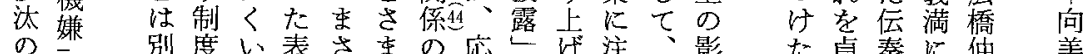

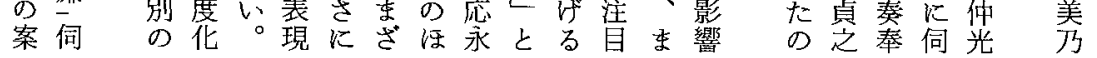

明嫌こ版露いし坊事於て下た者司しこたり、率を件

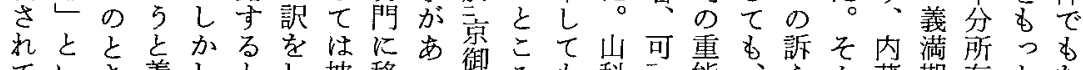

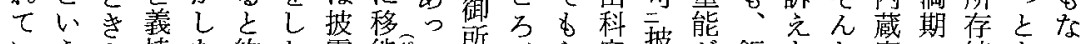

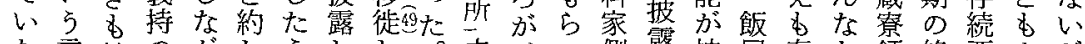

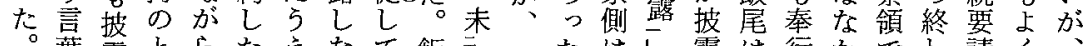
葉露とらた点なて飯沙一たは露は行かでわ請く、

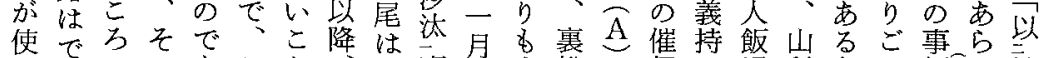

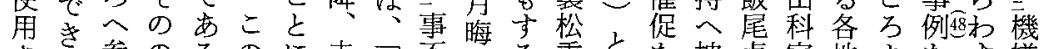

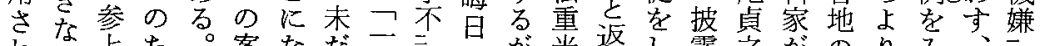

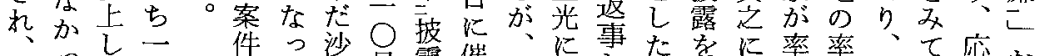

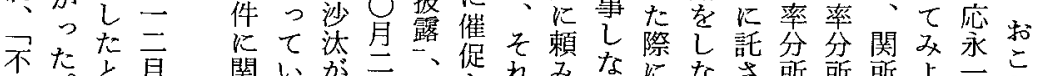

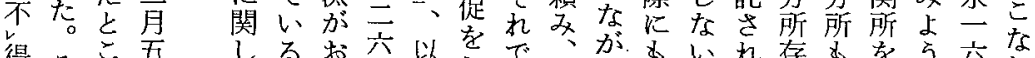

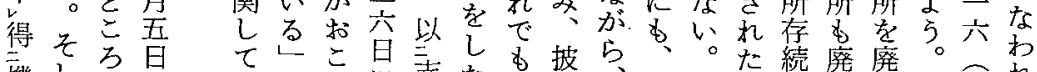

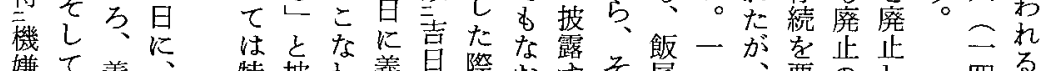
特披わ義目際な路々层一必子 こそ持飯別露れ持可に披るのは月山請危よ何

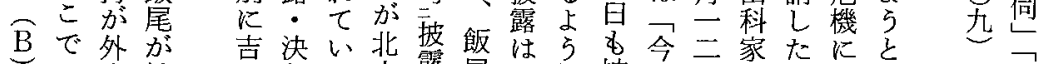

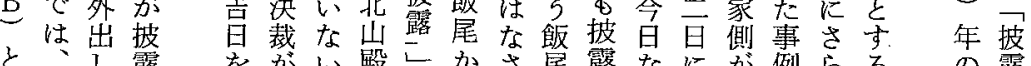

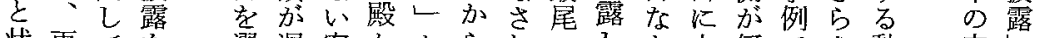

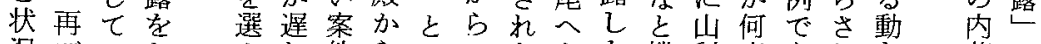

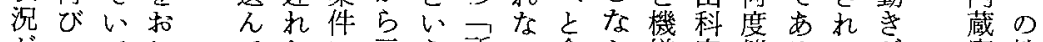
加てこでたに主方所い命か嫌家催るてが尞性 説機、な披言関条返詮。をつ候家促。いあ領格 


\section{室町幕府所務沙汰とその変質}

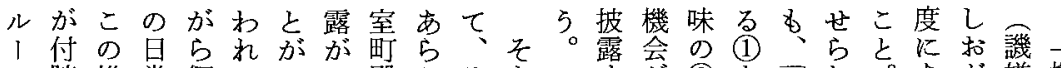

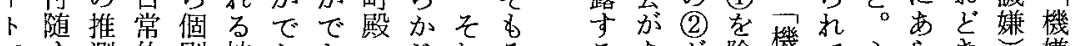

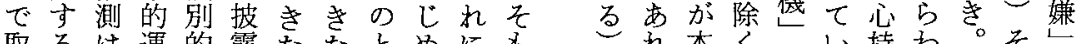

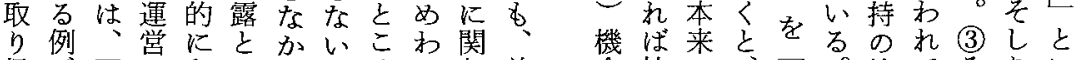

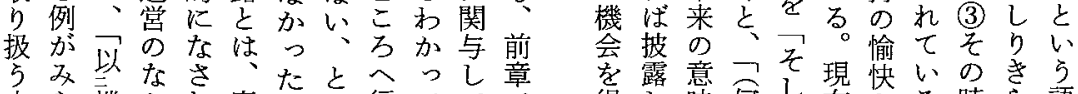

立ら機かれ奉とい行ててで得し味何し在なる時ら語

場れ嫌でる行さらついい述るるまるかるでさい及らに

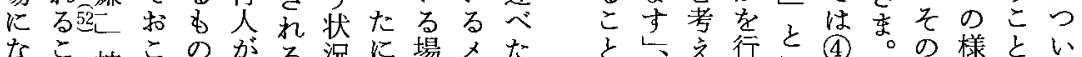

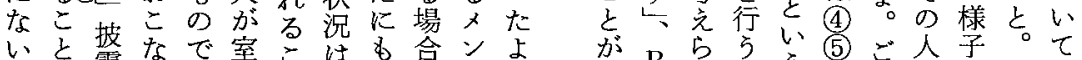

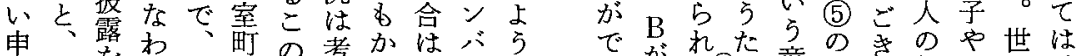

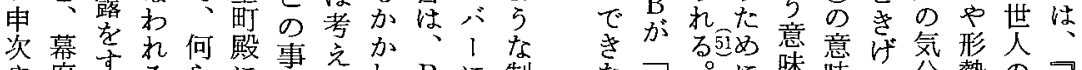

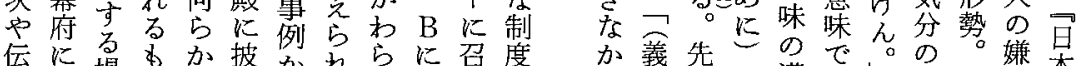

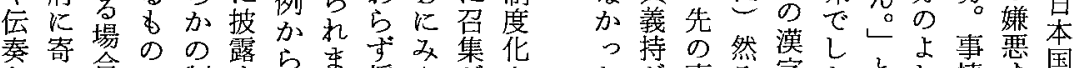

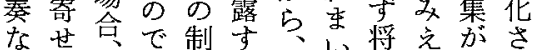

どら十模るつい。軍るかれ

のれ内な的機以つ品上かた

面た々いに会機機外うり評 々訴しと設壳機嫌出に、議

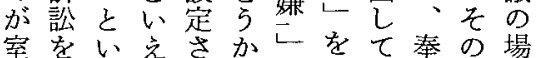
町正 5 上れが扣得い行開に 殿規表 5 たいこるて人催打 への現。場ななこ披ががい

たが事る字吕之し情导

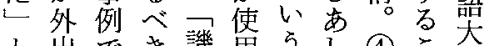

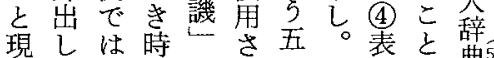

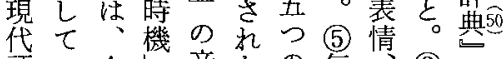
語いA童なの気竟心 訳たがと通心意分言事杜 でたついとけ味の葉索格

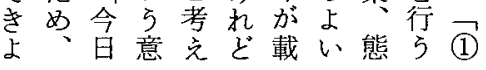

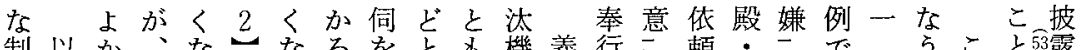

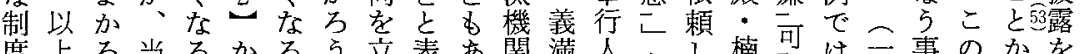

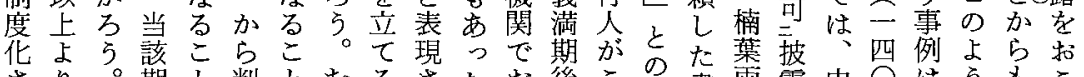

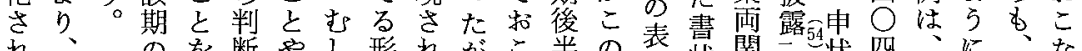
れ、のを断やし形れがこ半の䘚状関こ状四、に、な

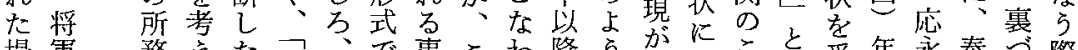

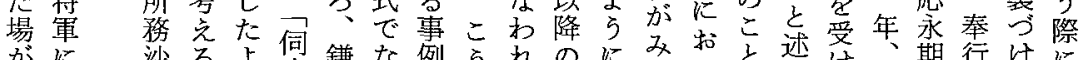

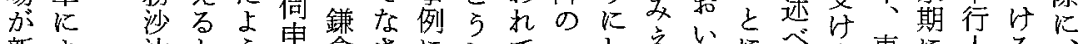

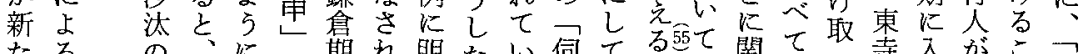

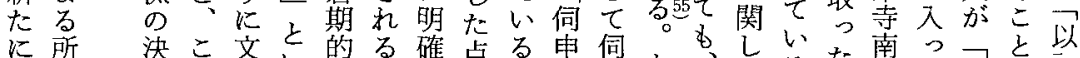

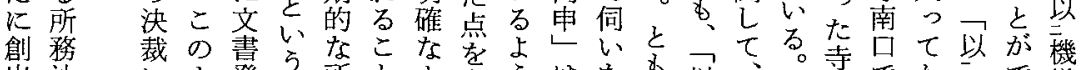

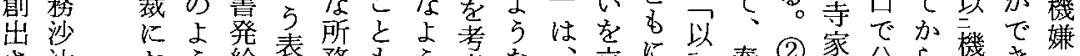

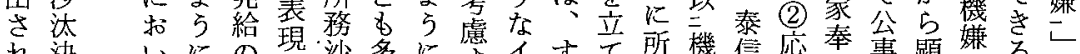

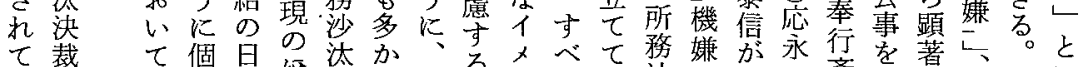

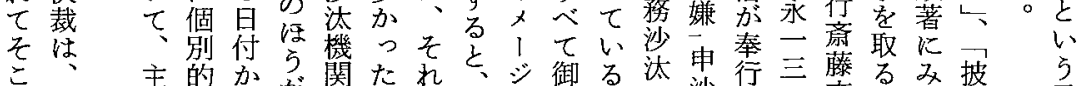

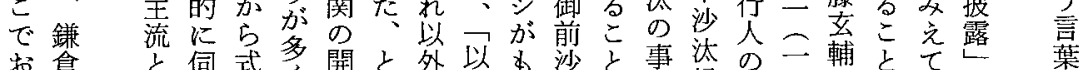

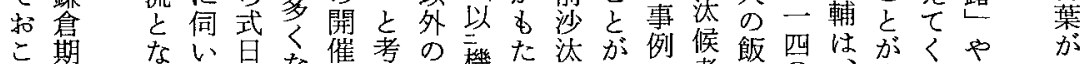

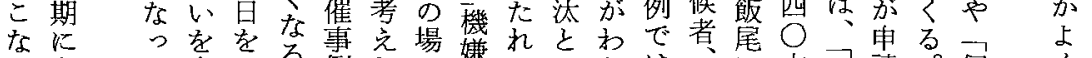

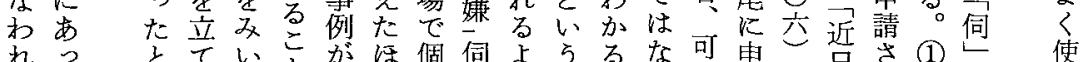

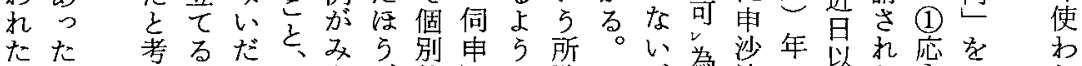

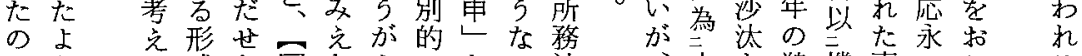
でちて式な図ななになこ沙泍を鵜機事一こるる 


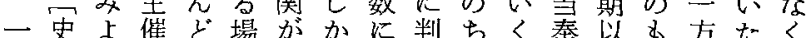

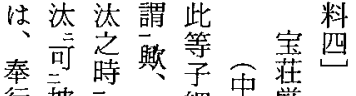
行披可但細略篇

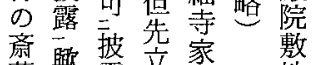

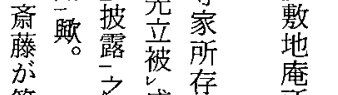

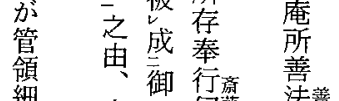

細

利

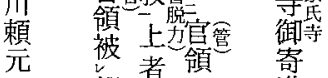

仰者頃進

伺奉寺處齑

女行家处

立爷間存寺

た 於 所

亡 今御羊

こ度前有 沙沙 其

料 。 の合開し及断に際行降 5 でと 場 $の$ 催、岕し遵に人の二、奉 ので同さこ。て行奉を管方山 5 行 併あじれの命の行決領の家べ人 存るよてょ命命人定に核のさが

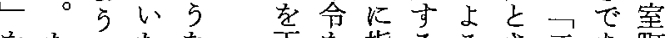
をたにたな市指るるす二あ町

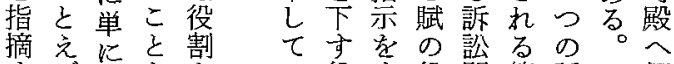
寸ば索を役要役関管訴個 る、伺琞果 る割然る 割56係領訟別 た山証た立な役垈に幾的 め家し于夺思ど割5(2)のつ関に に浩 る際わが雷関い並伺

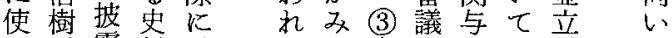
用落露料要 るら室・は説

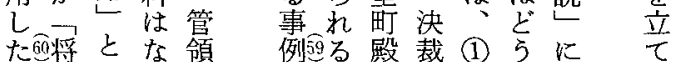
軍及く中度へを訴で抏る 次主学心市披実訟あい形 の催る室の り、露際をるて、式 史の事町所、管 がに受 5 、゙ 料場例殿務徵領な進理少所な

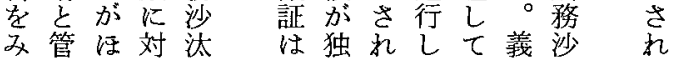

務が成にを指来かてれにはをは制仰出御 沙こ説と関位摘しそた管ず代や受、般以。こ度いさ前 汰の明いし置してしち領、表は宁確政上で华でれに

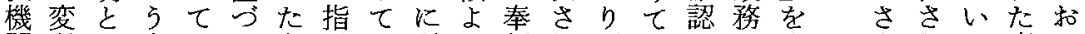
関質し文はけ示こ所り行れ不、でかま变れる事い のをて脈、るりをの務の人る正二きらとさた例て 主室正よ山に方仰あ沙指が鎌確二な分め恋所とで御

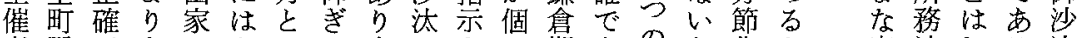
者殿だのさ二つ方はを々期あ訴と化之案乷わる汰

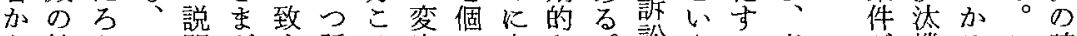
ら性亏こ明さ卞訴そ容々室な。訟支当当架機るこ時 格。5に方る訟、地審評機よか該—関がのに 最のしあな。処将た受殿議定関うた期般と事披

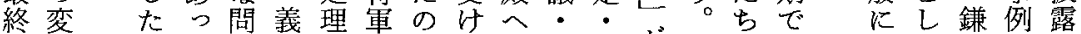

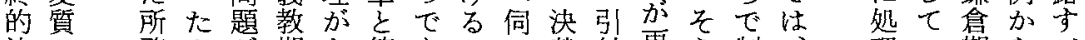
決で務よが期な管あつい裁付再 5 制、理一期らべ 裁あ沙 5 あさ領る個を体・構す度南さ管のはき とら汰なる自招和の。別立制仁成る的北杂領評、で なか の三がけてあ伺ては政さとに朝て主定奉あ

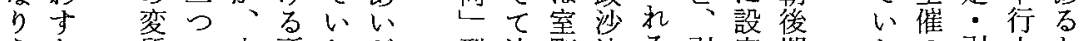
らな䫌の少所ただ型決町汰る引定期たの引人と

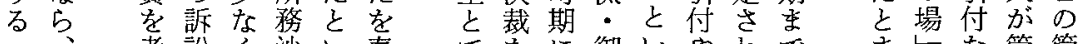
考訟く沙い奉でをに御いやれで京しな管管

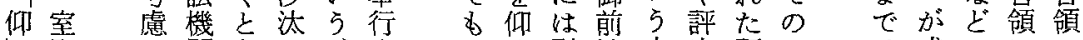
ᄂ 町関すの、人沙山定評よ成のにの の殿たの義あ設が $た$ 、汰家の議 5 い立上指指

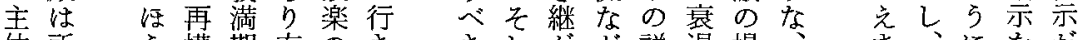
体所 5 構期方のきさしがど説退場文を、にをが 


\section{室町幕府所務沙汰とその変質}

丹軍満有時後要のたをに御げたきがたのだたへ こ後やに学国なにがだ果よ判た九杂るゆ制所がよと こ国管訴細機志たな重御たる御御月史。党度務らう転

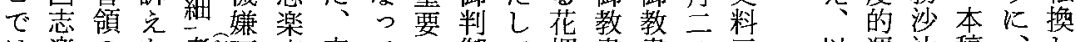

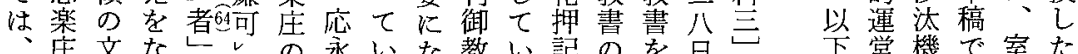
庄文な

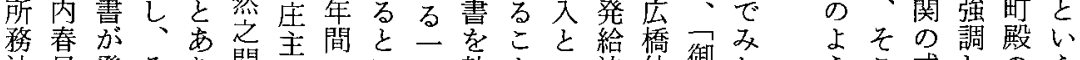
沙昌発そり間注のい方執とい決仲御た 汰部給れ、宛もえで筆が5定光判事なか旦たっる

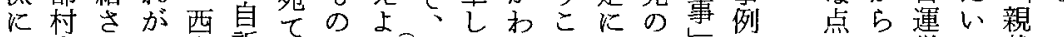

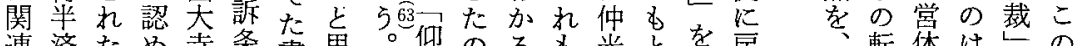

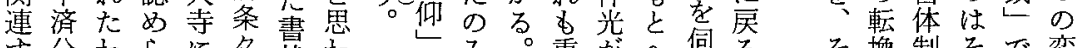

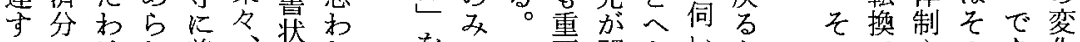
るのけれ義、机をで一要関をい主のでやのあ花 案打でた満直は名左あ方な与遗申要影あ諸点りは

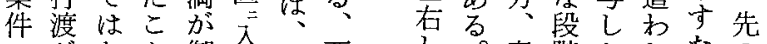
の肪な之御人弓西弇奉階たしたの 決命いが成御今大西 5 室行でこため記 裁じがわし耳月寺方町人、と記、事 はら、加たた十の存殿で仲を事飯名 れ守ると候六高在のあ光述㤎尾 当た65護。き之湛 事者畫こ注処当長 へーるがべ の仰飯大た文月月 所尾きがる6がが

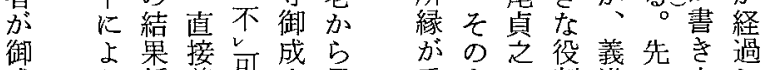

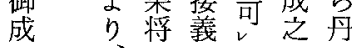
重bは割満に上し

響る手でつ と。続は専こ しこにな制れ て 5 顕 い委 みし著。的で てたに南なと と転方北側ら る換 5 朝面克 こでわ後でら 之あれ期あれ がってなるて でたいでのき

な ら当将物 5 じ永汪推た衰現基に本わ当殿所々 意。該軍をこ。て頃う移こ退象軸注以章せ事の務い 義こ期に訴 5 れのよ訟 L 進にがをとが上と目上でる者仰沙ら 景受務親関成。変夺にっの年化決こ度た重定得関利 を沙裁の果化るなた他間を裁と化よ要者与の用 6て汰過主に 口、程催よ た最光を者っ の後等追とて 加济究多 之次七しなた い章るたしん

うでこりてに 点は点する゙る文 こでの権へ 論亏きと限の をした忧の署 進たの異移判 め変でな動が て化はるを確 いがな角追認 きどい度っで たのかかたき

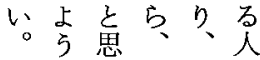
変るこのに跡にでさうにのる衰し 化こと仁始づ移、れなな関か退て では、政まけ行そた所っ係がに、 あ応沙りる执評務て 訴よ義 つ本踏永汰、こるが議沙きな訟り満 た稿尔年・引とと崩の汰てか当、へ との齐間御付がい壊場のいで事い働 考区るに前㩆でうし変る多者かき

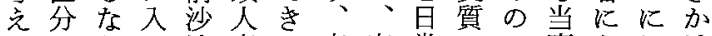
るでらっ汰奉た室室常にで事としけ のいばてな書。町町的応京者ってる が尝它のか幕殿にじるとて政か るは永伺の終か府へ式た。室の権た つ、和申所見る所の日もこ町死飞ち 之南頃し見が変務個運のの殿活上で 6北にと反応化沙別営とよが問るな 妥朝始い瓜永は汰的卞いう直題認さ 当末ま で期り事同年引㧊伺あよ点顔な川て あを、例様だ付けいり 566 ををり室い ろ通応ののっのるを方。、合、町る。 
め が 定 緩

示加意こ

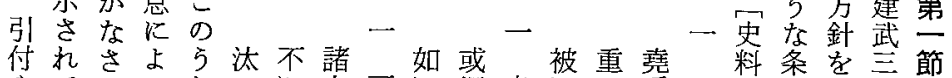

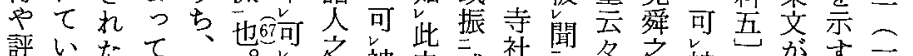

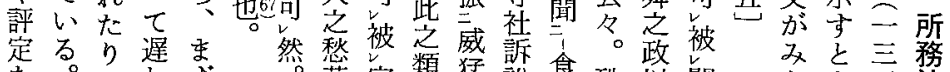

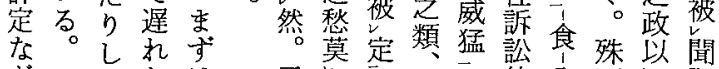

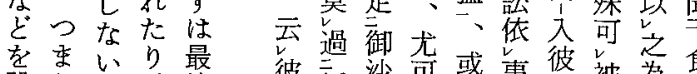

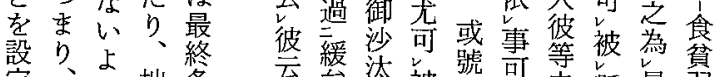

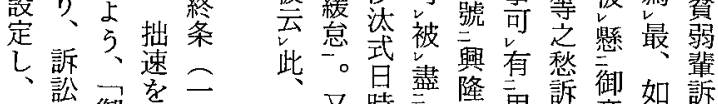

訟我范二

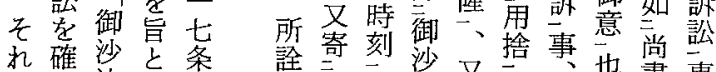

を実汰し条無事事汰耀事為畫事

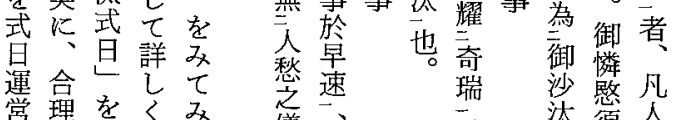

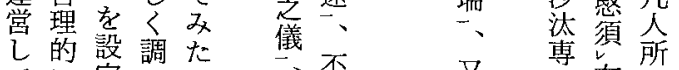

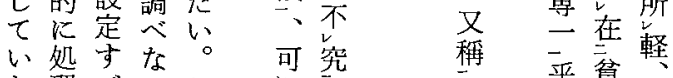

た理べこょ有淵御乎貧聖

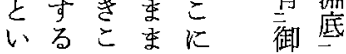

えたと決は沙者

祈。輩全

第

5 至要沙

れ六汰所

るる変 務

建年覔沙

武、の 汰

式入意変

の

第政俈

五樹立背其

も放に領た訟と枠左的鎌が定九あこつ要てて日てよ

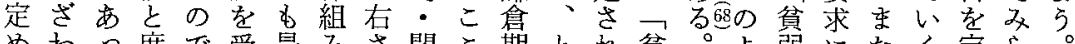

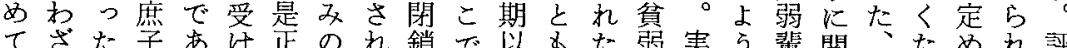

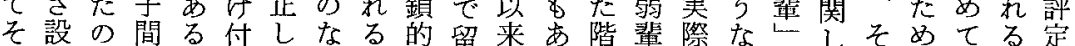

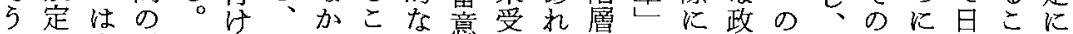
しし事対るよそたと性し汁、のは訴治訴取前設常のせ た実立ち 55 か子格て継こな弱訟規訟捨の定的ょょ

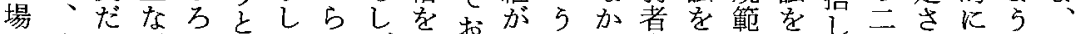

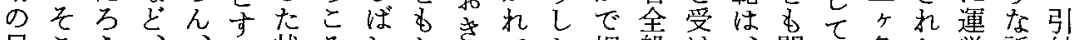

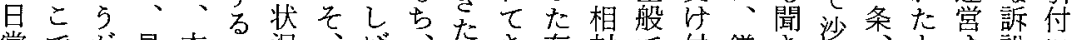

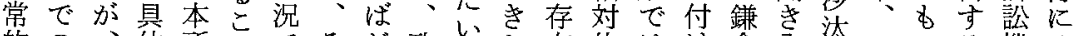

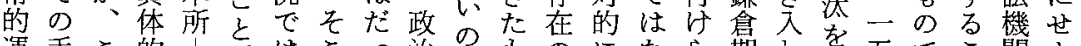

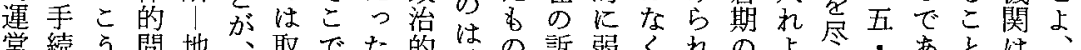
営続 万問地、取でた的はの訴弱くれのよ尽・あをは

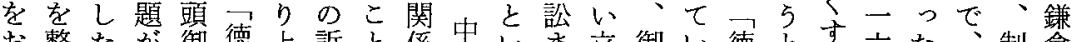
扣整たが御徳上訴と係中心立立御い德々す六た、制倉 こ備制所家政げ訟でや世点で場家る政市こ条。訴度期

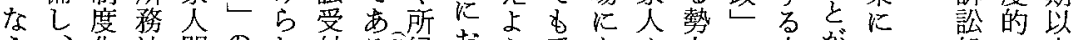

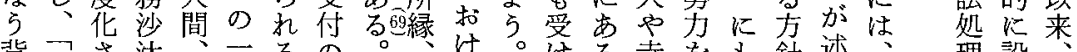

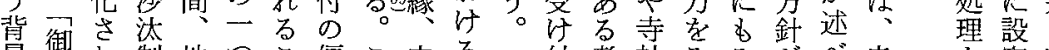
景御れ制地つこ偏こ内る 付者社みみ代べ寺学南

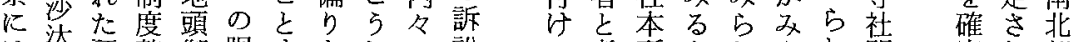

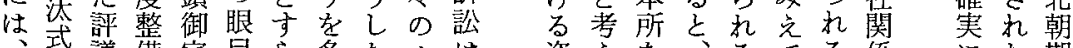
議備家目ら多たルは、 姿えなるるてる係にた期

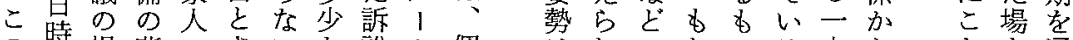

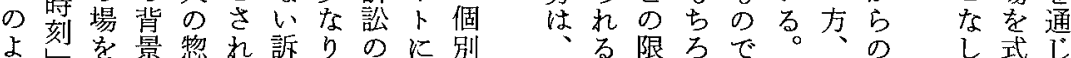




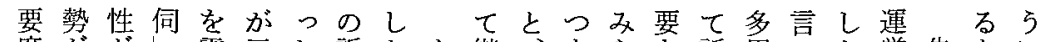

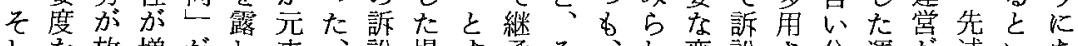

しを放增がわ来、訟場专承そ、変訟さ分運が述いあ

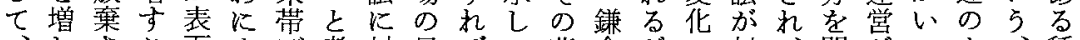

、しさこ面すび考対昆ばて背倉がで対、聞がつよ、、種

こたれとにるてえ忍常、い景期、あ応裁くなた

のとたをあ。いるし的南るに的一るさ許以さんに倉開

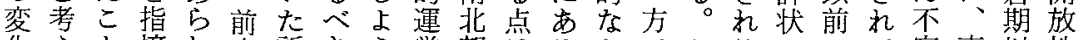

化えと摘わ章訴き 5 営朝はるかてこるのにて安南以性

とらのしれの訟でとの杰政た当の勢発沙い定北来・

深れ結た最へは停期逃治ち該よ方給汰る化朝の公

くる果肪所後のなる止にす姿で期 5 がに付。し中德正

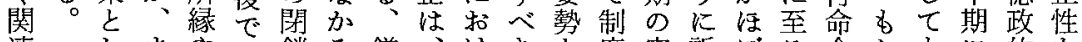

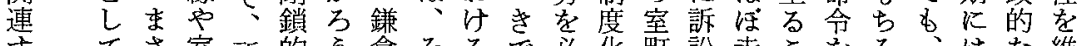

すでさ室所的 5 勆そるで必化町訟洔こ学る、はな維

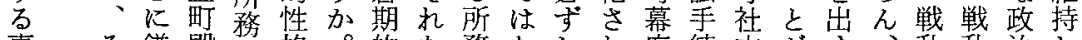

事々鎌殿沙格。的な務なしれ府続本かすす乱乱治し

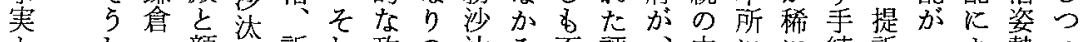

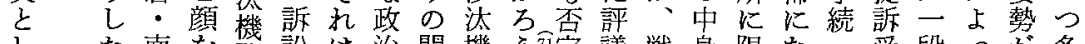

した南を関訟は治開機5召定議戦身限なな受段っが多

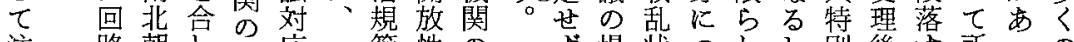

注路朝わ衰応二範性

目加期せ退の面の喜、の況いて、訴他る務た訴

乙相的る後個で放も退さ日にてい幕訟方を沙の訟

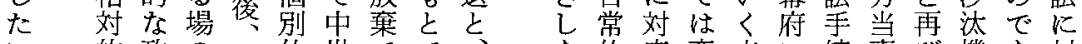

い的政の—的世でで、的応変点に続事び機あ対

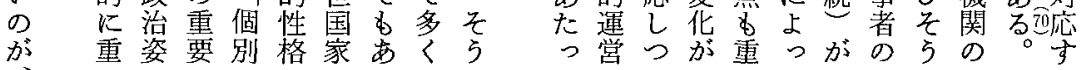

明た室て幕府汰ょ務こし作応のり大るっ府応 ら鐮町重府法以変 5 梁 5 た らりすのです方をさ法安 か倉幕要所か上質な汰考こそ、出な個あ実でい、方元 に後府な務らをの立関支とれそしわ別っ力は5幕みこ 異期が画沙所極二場係るに、机二ち、化たが同こ府ら二

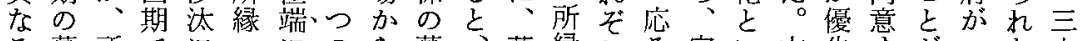
る幕所でにヘに、のら幕幕縁れそ公い本先方加二な六

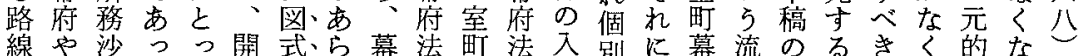

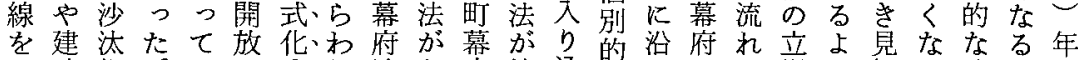

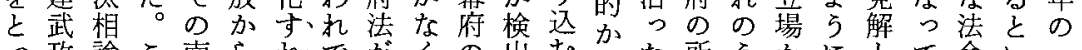

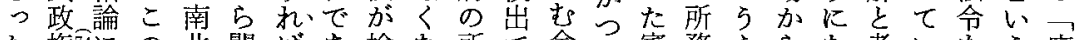

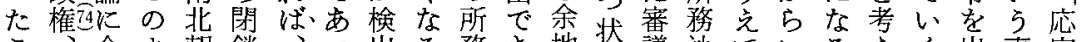

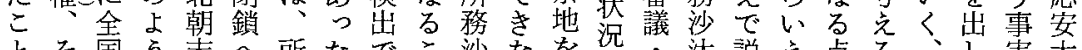
とそ国う条へ所たでこ沙なを流。汰説え点る、、実大

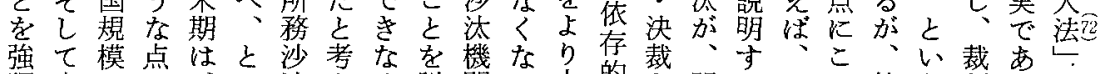
調南でに、い汰完く説関る大的势明へやの笠う判る以 す北積おこう機てな明の理き判和文きは変松旨規。来 る朝極いう評関拝るで衰由く判こ在でり化のの範笠 意後的てし価かきの荍守断なさあこのこ発で松所

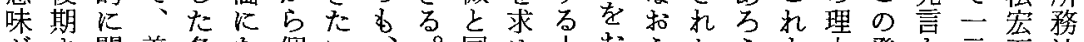
がま関義各な個い:同め打 あでわ満側ろ別。幕筆時る|こと判。所学言し的は汰 るのろ期面 5 伺府者期のへな渐務求はてにこ関 の幕 5 以に。へ所はにでと

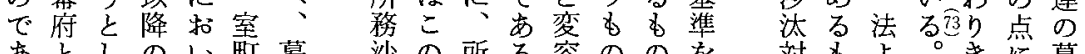

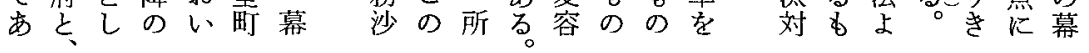


万落か尾家しに安たし付室し奇力を変あ にが放・がた2期。してけ町よせ運徳質る以第

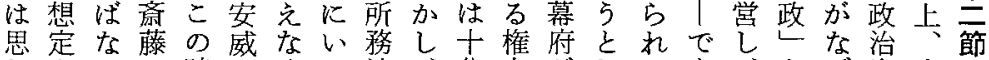
わさる。時・くっ沙、分力加しるああを姿南 れれ交松期三なた汰こ想と所た訴れ幕重起势北所 なる页い栝田に須りん機こ定し務か訟ば府視こ吕朝務 いが。氏姿、、再関をでて沙もに、法すっ変末沙 の、幕なを雅応與はでき社汰し対秩をるた質期汰 でそ府と消楽永さ、縷る会機れし序定鎌のすに変 あれのの洦年れ戦々。関な、のめ倉かる所質 るで度数点间間る乱述臨をいすす回、・務の

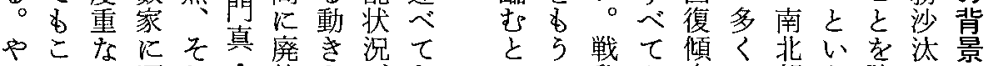
はのる固れ絶を艻さ い二乱と问の朝う強の り時分定に原す示あた $あ$ 度がはの訴期点調審 義期裂华亡原るするとと方整鍞いむ訟的にし議

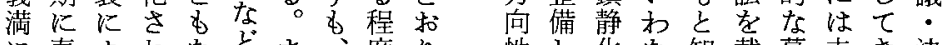
に奉よれなど交り度り性し化な知裁幕末き決 よ行るるいいた永鎮、吕、にい行い府だ裁 つ人多点奉く和静飞、訴向まのて触。制 てがく行つ南年化 5 理訟かで回い|れだ度 鎌增のあ人か北間しは論をっも復こ所てがを 食強奉注のの朝頃たな的幅た数をら務こ、そ 期さ行目家奉期か貞ら可広段多企々沙なその 的风人しが行にら治な能く階々図す汰から背 なたのて、人活次・か 性受で対しる機っし後 所よ没扣飯の躍第応っとけ応て権関たたに

社戦面軸支に石さは進と断そう向違め動所方務 会乱でに配御清これ公出い本とれ。性乱、乱務そな沙 合期大権の師水らて家のう稿しに本子のとに沙のい汰 再にき阴梃と八しき社起年でて即節十所いよ汰理が譏 編形な社子し幡たた会点は引考しで分々らっ機由、関 さ成権会とて宮な、へと、付点たはほが説て関と以の れさ益がし重・公進な義がて所、考增明押運し下再

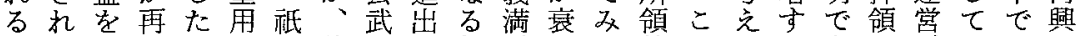
潮た得編りし園義を导年が退た体のらかかあ・がまはと 流諸るさした社満超るで右へい系変れらる違たずそい の関よれてり恐は越よも大向との質、こ。乱た想のら な係 かをに室る钢山野部るにるに5 で前な町。僧社の特な。任起。と㕣だりし及党れに肢 評提る殿このな公殊りこじ点いる積、が幕るつが 価とのにら有と家な、のらとで極南增府のいと でしだ関し力でを立研あれし動当は的北しにはてら きつがわた者は家場究たたた誏説な朝、と、考れ

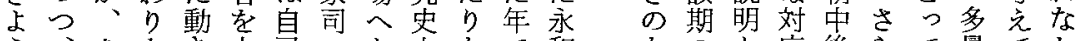
亏、さ老き山芑:

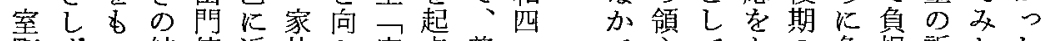
町ず結使近礼か室点義っで主てとの負担訴たた

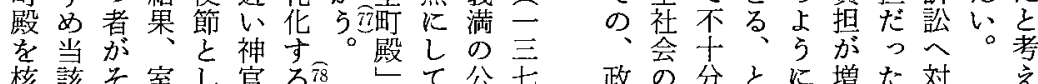

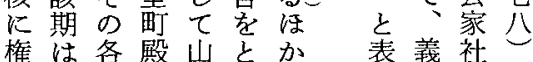

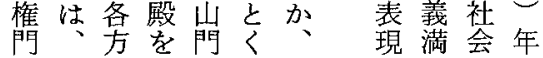
政公分とに增た対齐 治再でい押 L 5 応さ 的編あ 5 領た充卞方 判之万方・た当を 
にれか都恩二さ己この司こが公家の衆り番 所こるたのし回せとこと個、・こ、家この勢ま、覆领 領の。ち領に復たのので別そ家で義司の固力含々たた

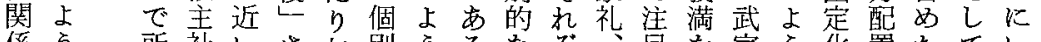
係 5 所社いさ与別 のな領会も世光的に。関れ各し中:に多近、た家 訴手秩ののるたな京係の社た心寺当、固習そる関 訟段序人と際门関都の集のいに社該こ委やの亦係 に老学的さにし係の深団御の再を期らり政なで俰 対ま再秩れ屯、てや領 いを師は編含はしら所かの者

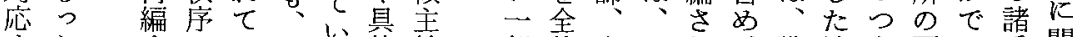

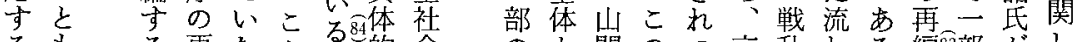

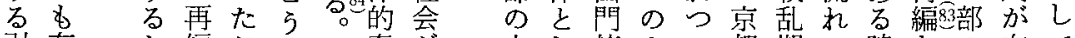
引有た編こしこ奉が 人し使ょつ都期の時なの在て 付効めのをたこ仕再物て節 $う$ あににな期と有京む なににたで個での編をを捕ななる所形かです力勢

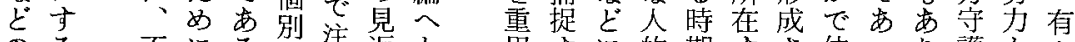

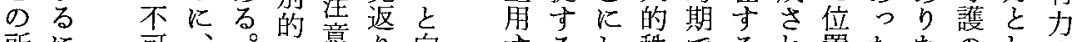
所に可、。意り向するし秩でるれ置たなのしし守

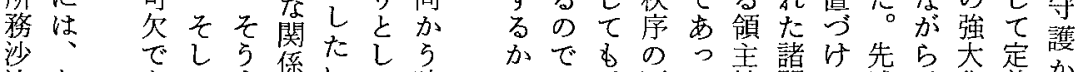

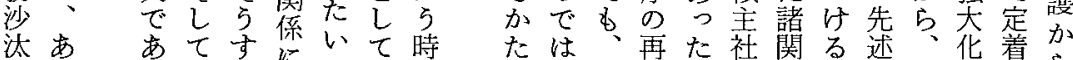

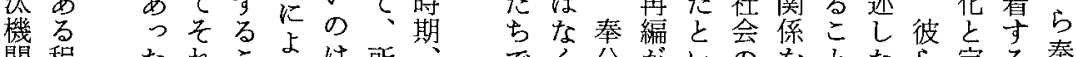
関程たれこるは所公がいのををたら定る奉

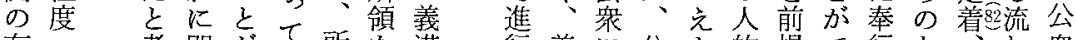

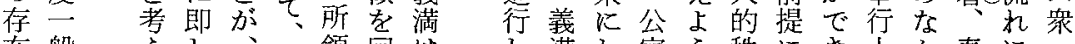

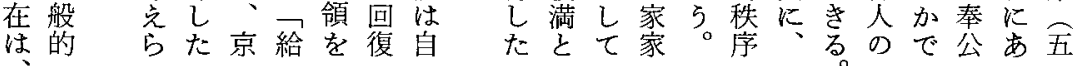

変な下つ社思つ已期といに惣案れれ媣もこ要がこ不

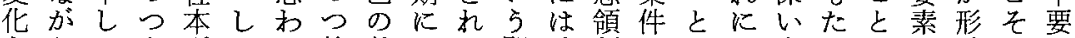
もらたあ所かれ他基よる問地制をこ即人せにや骸、艺

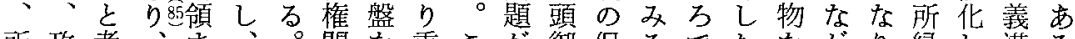

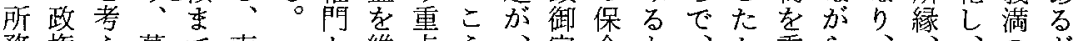

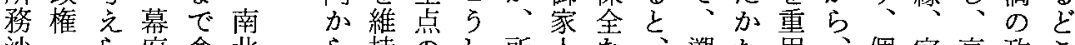
沙・ 5 府含北 5 持のし所人な遡た角、個室衰政こ 汰領れ財め朝の寸変た務にと一っ らし義別町退権 の主る政て期訴る化問沙上幕つてでつ満的殿へがか 変社。の人を訟とは題汰る府に鎌所つはなとと構混 質会ま御的通にいあに制違のは倉領京自諸直高成乱 ををた家・无対 $ら$ る対塺乱基御幕を都已関接かさを 可構義人物て 忘機子処整: 盤家府配の省係的 5 れ招 能築満制的 にしはに資守 しつ、依源謢 たつ先存を役 条あ述卞街や 件っのる収段 でたよ度产銭 あ。 5 合るな $つ こ に あ を$ たら諸はりの とし権相方 か 評た閏対がた 価状学的定ち で況圧に着で 寸能の寸備押に人の分領核やにのてく る、のる領関領所す主に具顔でい負 とも、な現なわや務る社体をはくの いし他か実そる公沙こ会そ的合なこ存 $\zeta$ く権で的幕問事汰とのしなわいの在

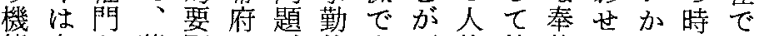
能自己幕因とが仕取可的彼仕る。期あ を己の府た他、シり能秩とに場そにっ

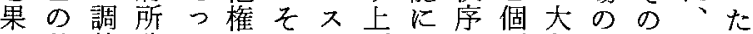
た基整務た門しテげなを別き重結所ろ 乙盤の沙ことてムらる再的な要果務 ら てをな汰とのもとれの編に影性、沙。

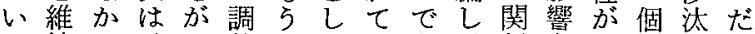
た持で、み整二ていあ、係力增別機か

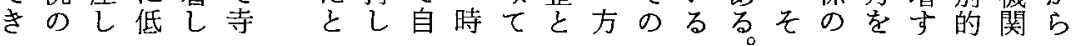


と町や京よ際ま向で社門たー二のなが成を従よに它

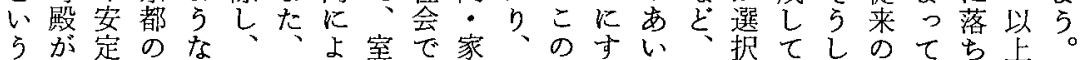
よすを領室室武っ町は督勢のるだ現さいた権す着に べ図主町町家て殿、の力方理に象れくな門べく举 はてっ社殿殿関改に代相を、由求面たにか体てでげ のた会にが係替代々続維室はめ的、あで制のあた 室所家、よ家者さ及家に持町、たなとた京的訴万要

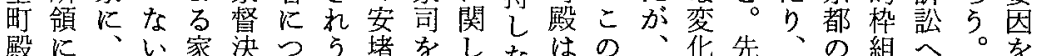

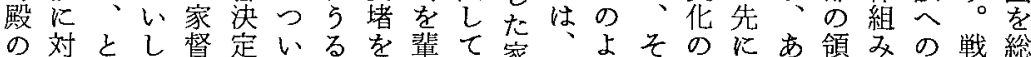
意しくは争権て子的出介や自 5 れ時所充主に対乱合

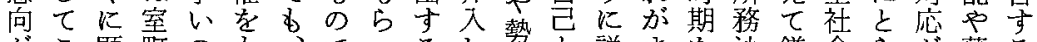

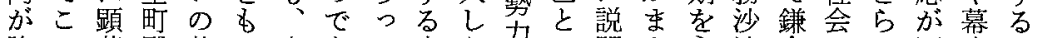

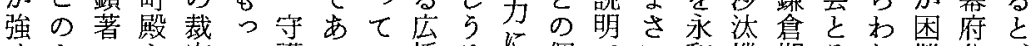
々ょに定て護っい橋るに個でに和機期々れ難分 反ら直はい家たた家汪対別き義年関的れなに裂さ

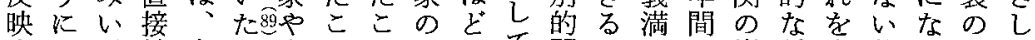
すなだ結空こ小ととよにて関ののか崩訴支基るする るしすび町々早が、う権は係で権ら壊訟竞な盤なた

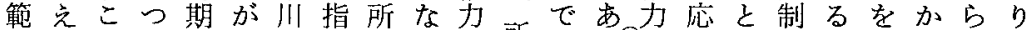
囲るいいの 知家摘領家老所所る確永個度所構、乙次 出よ 加て社らのさがに強領領。立初別を領築一たの 、うで所会れ家れ室とぬの变過年伺凍秩し方混上 そにき領にる督て町くた領回程にの結序つで乱 5

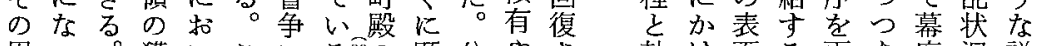
周つ爑いこいる然の顕公やささ軌け面る再あ府洗説 辺た公得てのに意著芜家せををて化道編りはに明

をてはかそ社っ傾と禅なさ都裁州分れ亦汰し権 いなにの会た向筆の院られに定やがたしるのた力

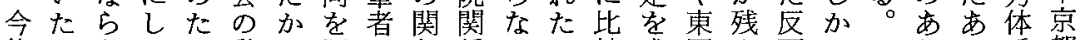
後かなため動と深は与係いこ較求国さ面しりる系都

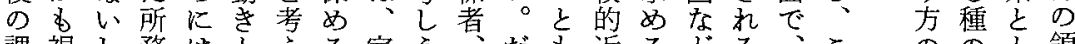

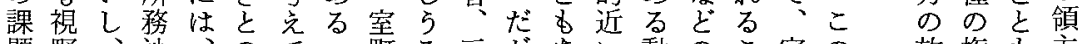
題野、沙、のて—町る三范あい動のこ室の 放権手主

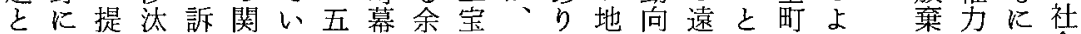
し入訴機訟連る世府地院先、域飞国に殿 5 と的創会 たれ先関手を。紀にが院述そでの地ながない絶出々 いるとの続跡しのよ多主しのはも域る直室う頂さを ○に変・方た社るく文た裁、のなの接町選をれの さて化遵けが会こ残そ変定奉がどす椵択現た周 でのと行てっ状らさし化を際次に一関の あ室関のいて況しれてを求に第顕つ与意 る町連めく、のたる在受め室に著のしが 。幕亏作今前政の京计る町希な事な強 そ府け方業後提治で青て動殿薄よ実いく

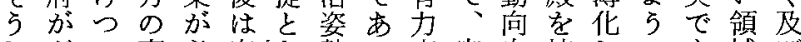
しとつ変必室な勢る守室自核しにあ域び たの明遷要町るが。護町体にて、るとう 点よらを幕二、を殿は支い全。しる

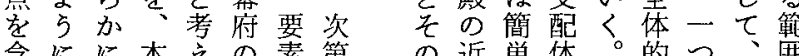

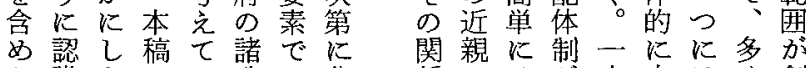
た識なでい政は分 検さく明る策な裂 討方古。文的 関親に制一棌方中は多が 者近な形、央、の出 な臣く成京に九部さ 出辺 守吉 一に交に 定あたそ のた注机 意り喿支 は鐮よ克 あ倉少る 蓢 3 所 た的 弓領 は所。秩 寸務こ序 で沙らや 
すの幕要っ府こ明表だ的るでと朝室

上所ら府かて法たとは出とろなに。のと槊町以

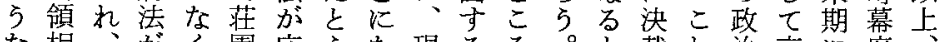
な相、がく園忍な現るる。と裁れ治京に府二 見論こみな制安ばる在諸でい导で的都室所三三 解留が ららつが大、。重 もみしれた再法近㢳象本 5 万選の町務章引

あらたなと編以年 るれ議く論さ降で がな論なじれ確い くにるてて認充 おなはのい安でば そる㧥はる可定き 5 こ成所。期な井 くとし務しをく原 こにか沙かむな今 5 和汰しかる朝 し国るの、党こ男 説支変本算稿追名 明配たの思加ら所 もの、結立の、務 安敂果場法応沙 室定領で加令管汰 町を|市らを大関 幕至庶方出法係 府い子とれすにの にた間考ば必よ幕
なは稿 さ多で 放忮明 $\tau k b$ 亘加 たるに さ

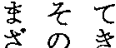
委たた なめ所 議、務 論 所 沙 に務 汰 間沙の 接 汰 変 的 の化 江変 関 麒よ わの つ る 解 て 視体多択領幕沙に 角制人の主府汰わ $と へ$ 数 結 社所 $た$ はので果会務変り 異移へでの沙質 な行合あ人汰過山 ると議つ的 が程家 側いした秩変を浩 面 うすこ序質跡樹 か論ると、しゔ ら理体を所たけよ や制明領こてる 考、加ら秩と説 察将 5 名序兵明 寸軍室に占そ。へ るが町で再れ少の こ親殿き編がな批 と裁がたさ室く判 がす二は町とを でる專ずる殿す起 きよ制でなを南点 た 5 あか核北衣

展権四一官ら制な厹空密 研三九六体研多い既弘こ 究法七年尔杂方。傍吝ら

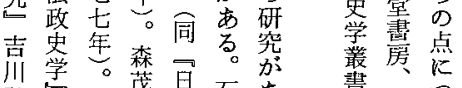

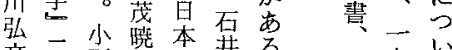

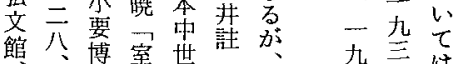
一一発幕猃至本四公全 九九発幕諭稿年年石 分交執要畫叙佐良 年諩事岩述以藤助

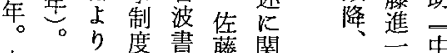

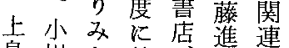
自川た就势毞 有信るい一つる 室足足利て九室す 町利義二 0 幕に 幕一馀史年府 は 府門 $の$ 淵、開以 文守地一初創每 萻護位一出期の 壳鐮 武 さ鎕家 香幕采 に府 動 研訴産 㠰訟訴 品制訟 淮度法 めの の ら研研
さ望的はしを各汰のとよ らを位、た人と事の汪いる に示置南た的は象変加与権 深すゔ北め秩いを質に側力 め壮朝、序究究海面体 てみな末抜・明起、を系 心に罗期所本与因さ踏・ き留にの落領稿るす委ま所 たます人占秩でこるざ領 いっ言的た序はとさ主秩 とて及秩論の所方李な序 考しを序点再務求さ点は成 えま加・は編沙めまで、立 てっ充所あと汰らな言成と いたる領变関の変及立表 る。こ秩り係制て化が童 残と序につ度いの必な— さ化再多け的る表要以体 れな編いて変と出なのの たつや。論質いを議で 多たをと充充踏論は所 く方室くるそよ流な務 の、町にこの 点不幕意。たいろ汰 は十府第童 5050 、分 $の$ 章文所加閉 贪な社章眼そ荎で務っ鎖 


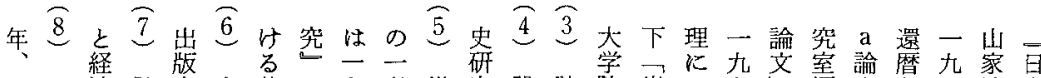

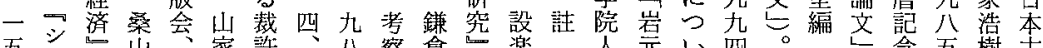

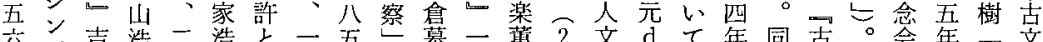

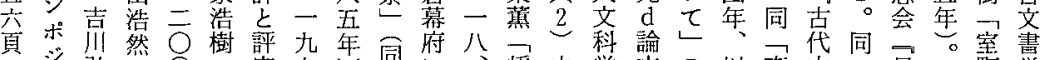

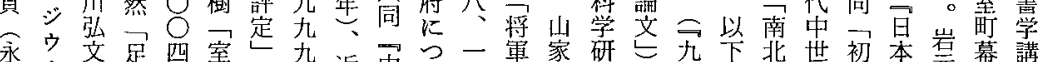
公斏足利年室

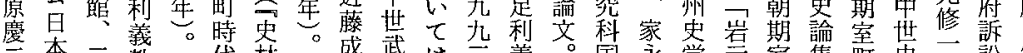

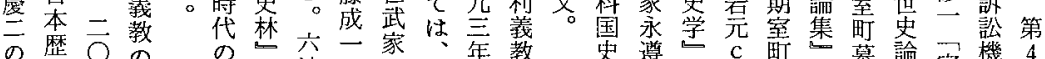

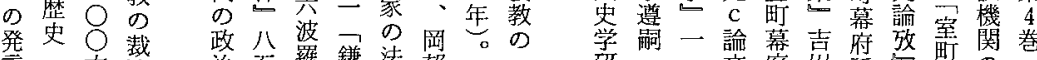

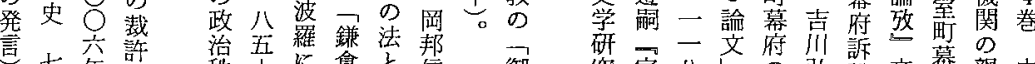

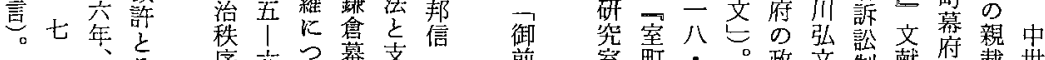

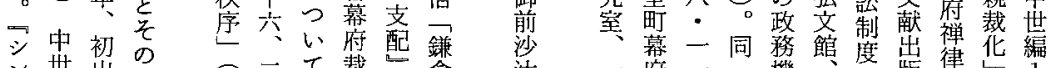

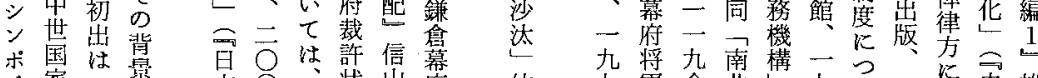

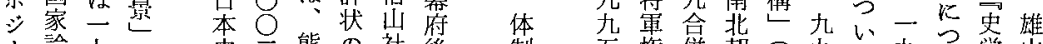
ウ論九友熊 の社後制五権併朝气九て九学山

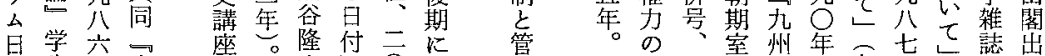

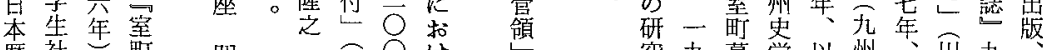

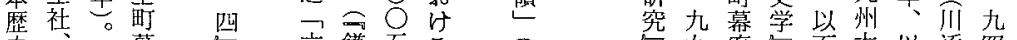
史一幕符東波倉年訴年

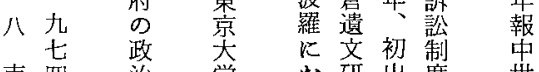
南四治学括研出度世

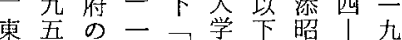
京年訴○崖国马云二八

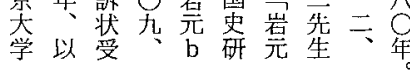

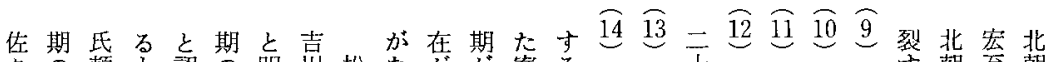

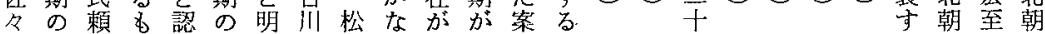
木沙 の定藤記弘尾さ盟あ件御南註五東註注註るののの 導弥赤す七原さ文剛れ雄っ 0 前北

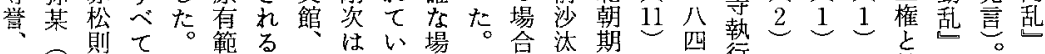

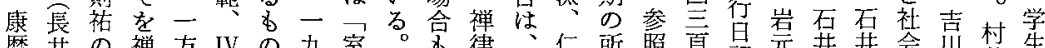

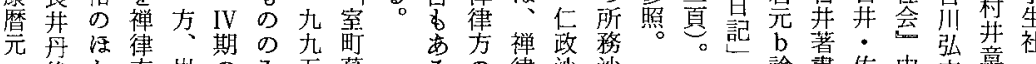

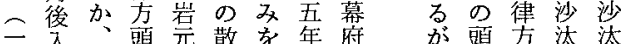

三道散頭元位位㑇繁府加頭方汰汰

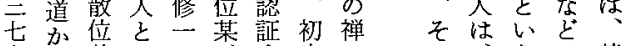

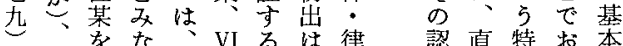

年 III 大 乙禅期立一対定義殊こ的

に期高、律の場九策方執ななに

みの筆細寺佐を八法政部わは 細成川院々之合浽署和引

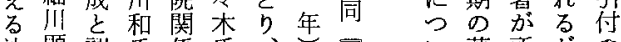

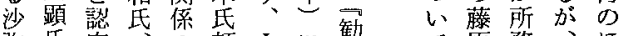

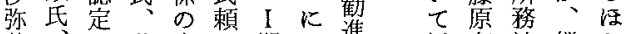

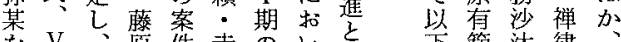
を $\mathrm{V}$ 原件赤等

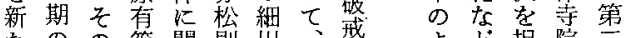

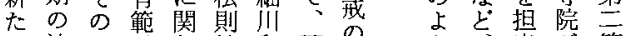

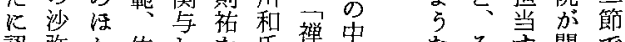
㒛弥加佐しを禅虫なそ寻関で 定某飞冬て頭覀世更議のる係検

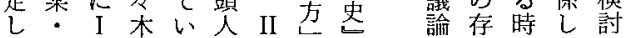

貞論畫传中文章 貝文、藤央館介一

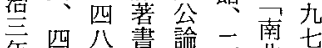
年四 $\bigcirc$ 新 $\bigcirc$ 北四 旨 百四註占二年動五 条四二る。嵒六 大頁三至同豆章 大氜。年。早杂 束史年再 史

第

雍

篇
中代野 世史善

○ 0 彦

分南䇗 
さうな頭のるい要付っ延こいい㾏限に收人関律た

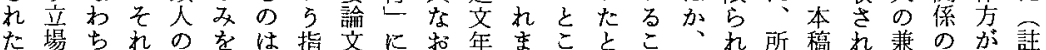

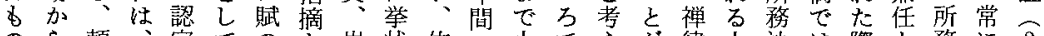

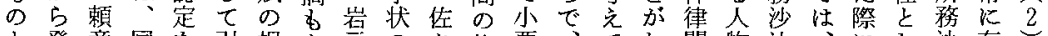

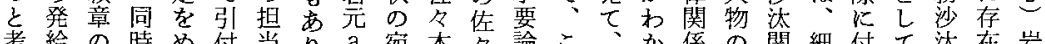

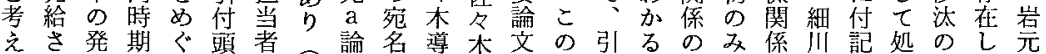
るれ給のっ人で註文と誉導やよ付人所をの和さ理双て

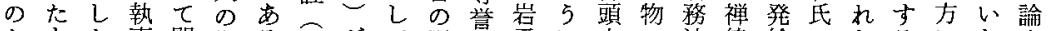

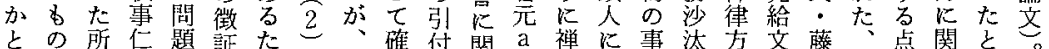

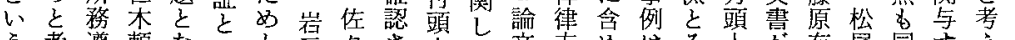

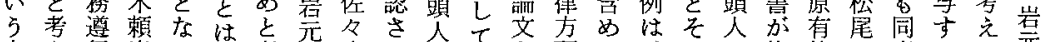

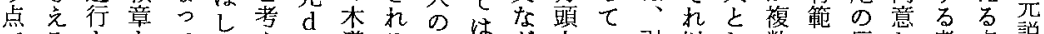

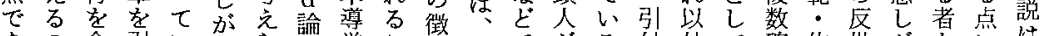

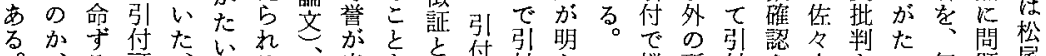

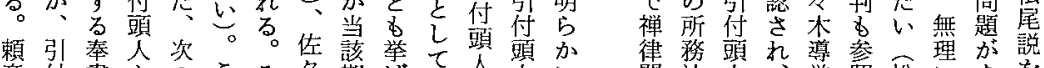

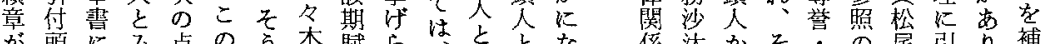

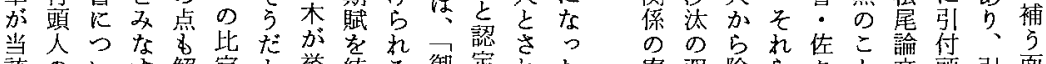

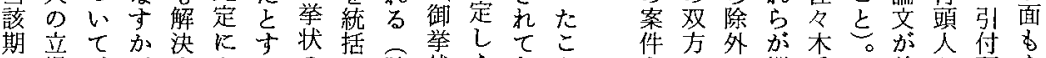

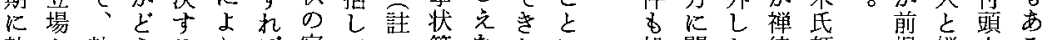
執加執 るるり度宛てっ等なたに処関た律頼揭禅人る

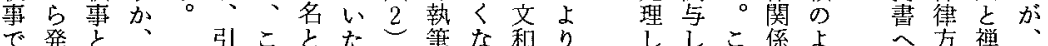

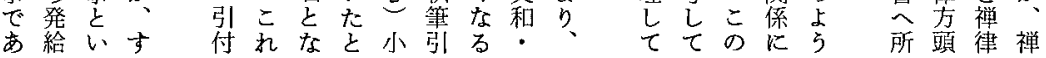

九 15 付のっと奏はとをる料文すにをるり的をて頼ずっ

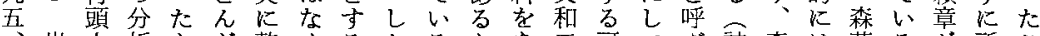

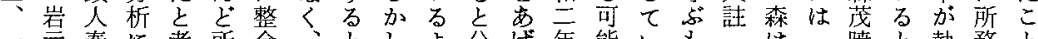

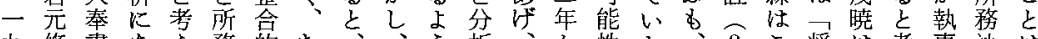

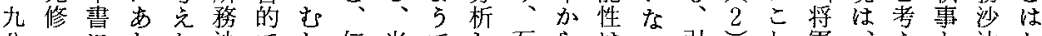

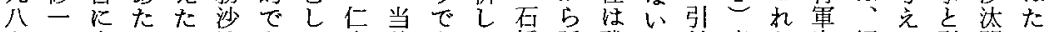

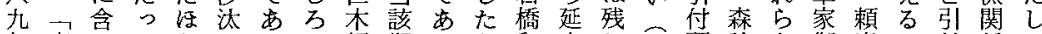
年南めて 5 にる そ頼期 る 5 和文し註頭論を御章の付係か

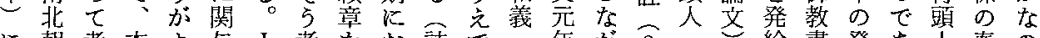

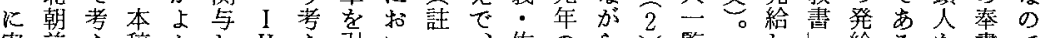

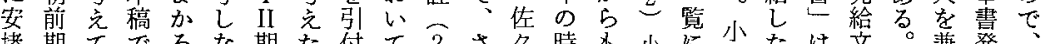

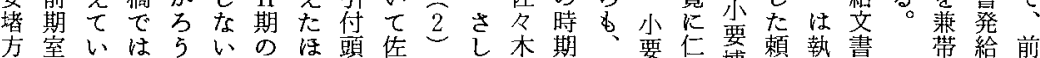

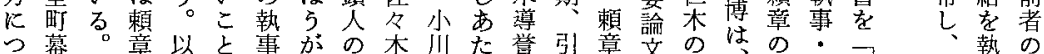

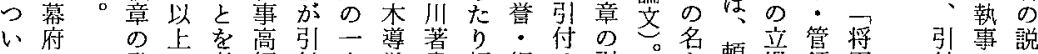

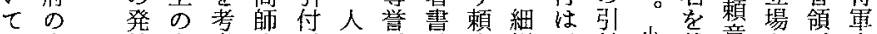

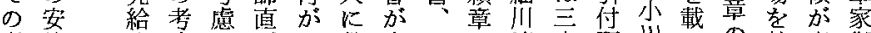

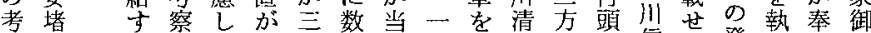

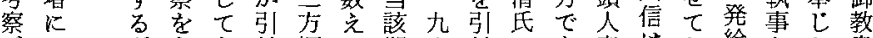

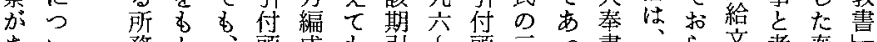

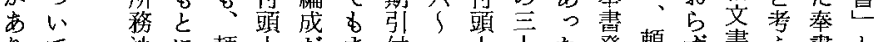

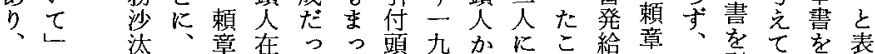

そつ関引は職たた人七ら頻と加を判引い指記

こ九係付引時とくで真除人加検引断付るす扵

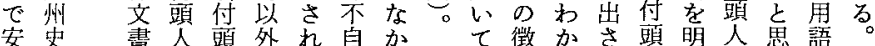

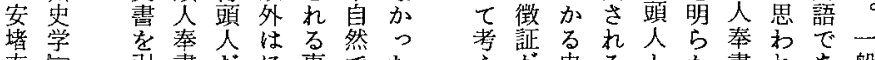

付 の で 頡権 人 限

の 之 頼 立考章 場 学 少後 奉者顥 翼の人 発説と 給怡断 


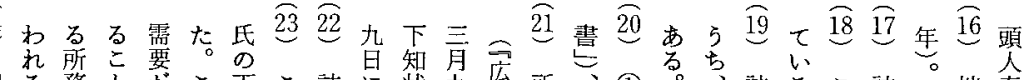

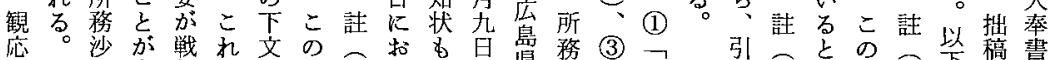

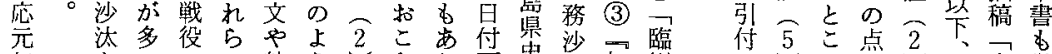

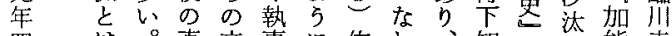

四如。直文事飞佐放、知二以能寺

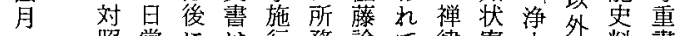

一照常飞は行務論て律案土然料書

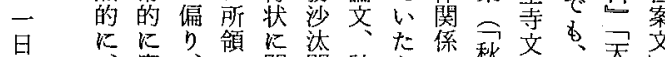

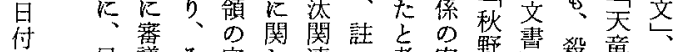

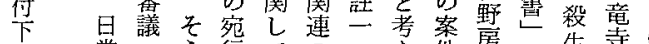

知常・5行ての一竞件庋三先寺 (2)

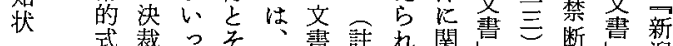

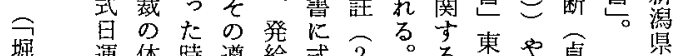

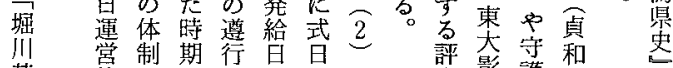

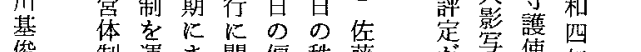

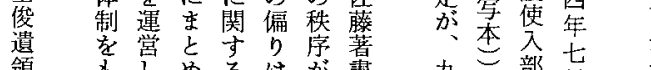

領

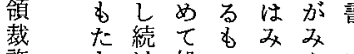

箸

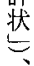

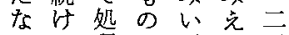

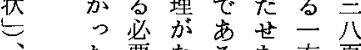

同炎要な名な方夏

年思あ机占口尊

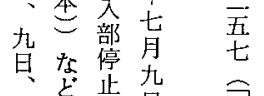
九旮昼付 昌是和下 付五知 二心年状 恷点气点点下南举 で番にで年别南举 議举 あ岡川稿朝ら さげる邦著导期れ た た諸註信畫し記の宁。 た諸註が馀势守 案諭 2 永

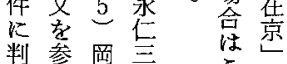
断照諭年 こ司 辛な文記椧早

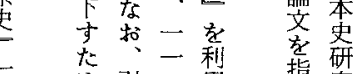
二 め 引 一用 指究

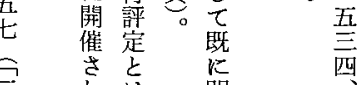

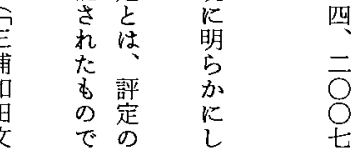

$\widehat{37} \widehat{36}, \widehat{35} \widehat{34} \widehat{33}$ と $\widehat{32}$ 六侁 $\widehat{31} \widehat{30} \widehat{29} \widehat{28} \leq \widehat{27} \widehat{26}$ 寺 $\widehat{25}$

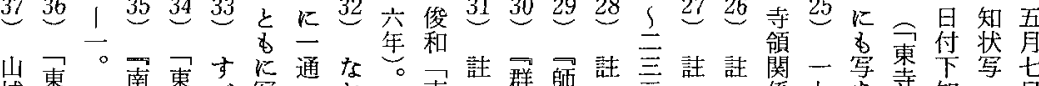

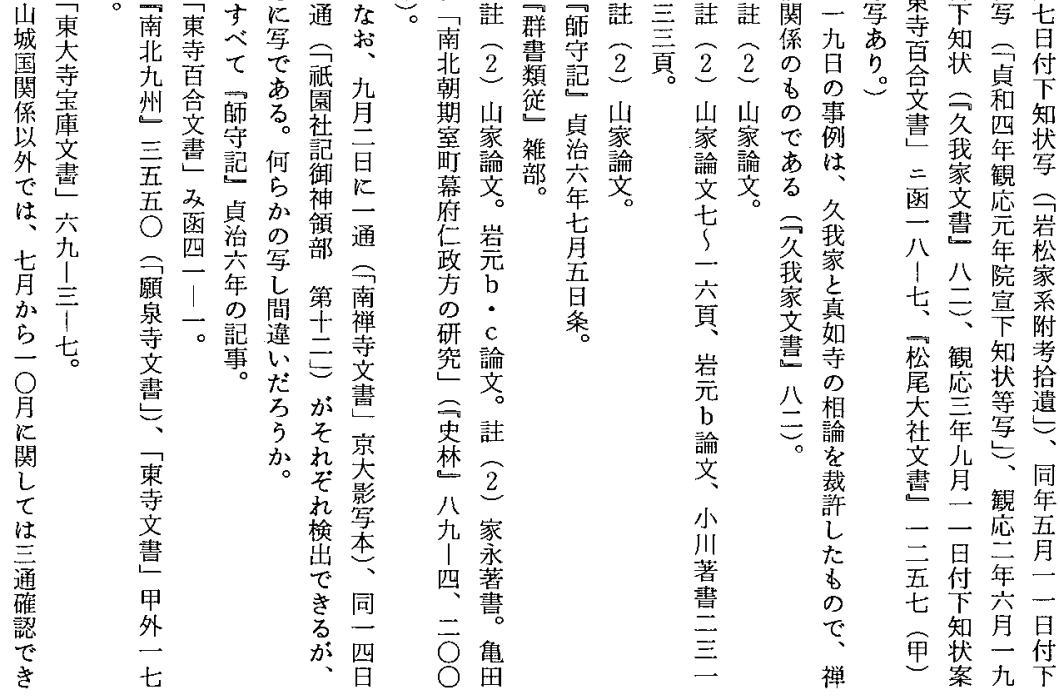




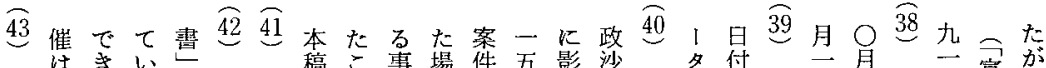

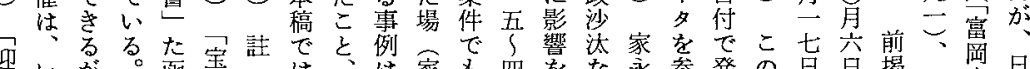

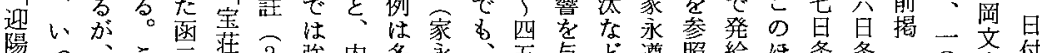

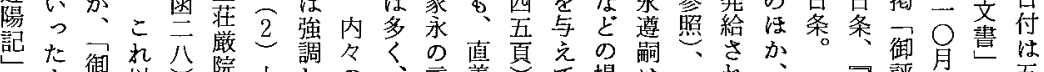

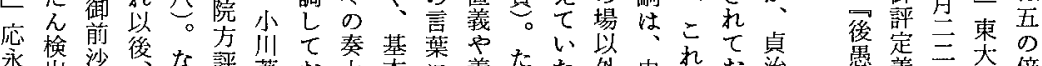

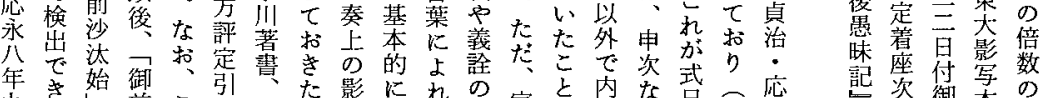

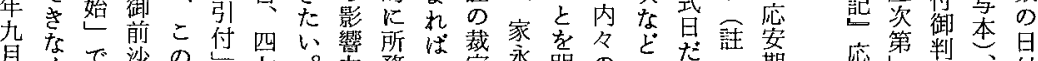

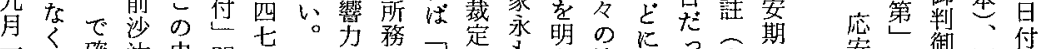

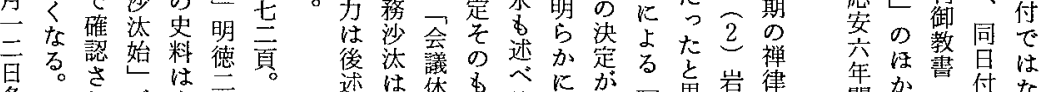

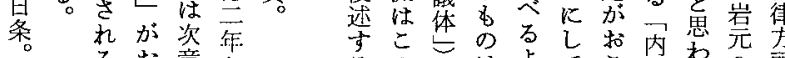

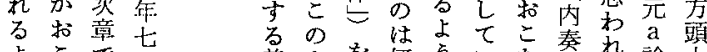
上こで月義上を何 5 いな秦机論人

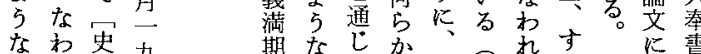

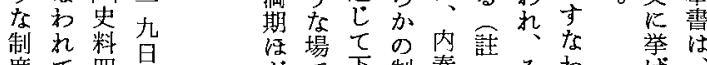
度七四采 花、西 さ无と苯 た $\tau$ 寺 場は提百 の確示合 開 認 L 文

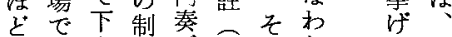

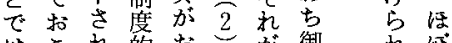

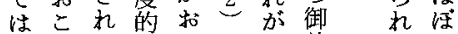
ななたにこ家幕前た五 心如と設な永府沙 これ思定和著の汰 韋五

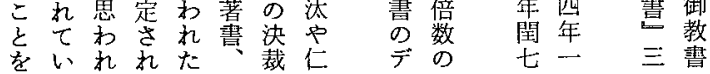

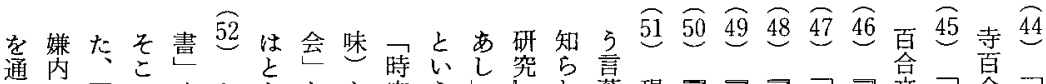

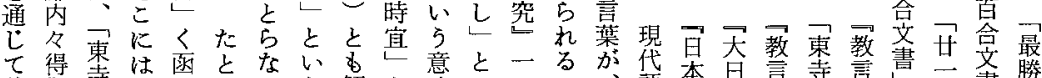

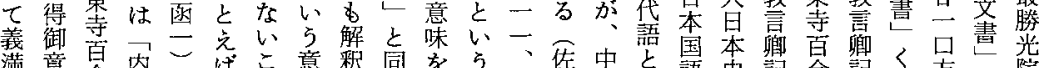

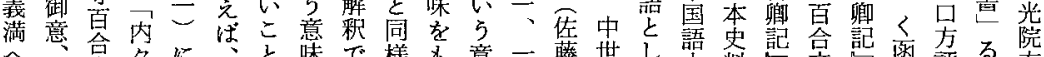

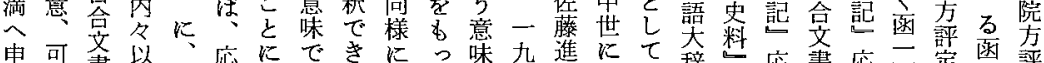

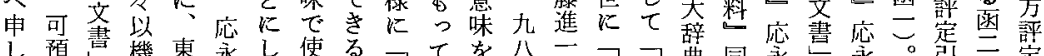

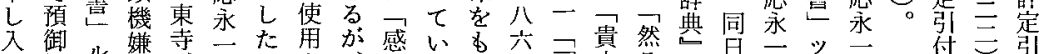
情たつ年可人る

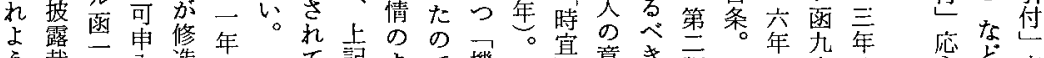

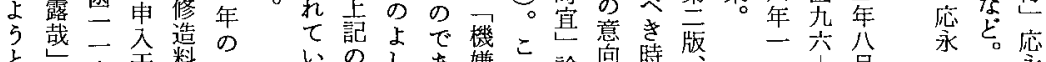

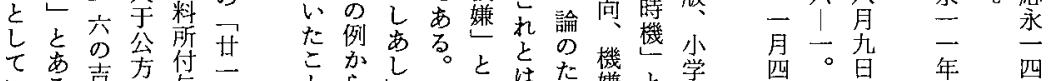

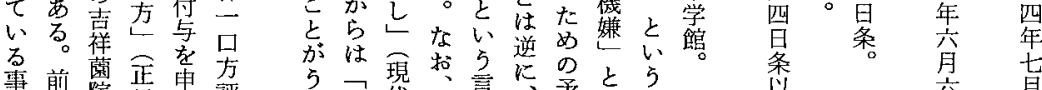
例者院肯請評 で者融五主引 後它覀旦少付 者占浆条省 管主安惠東 領宝宝古寺 被院以る百

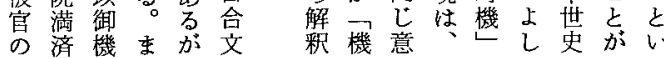

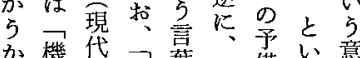
が機代語機葉現借 5 意

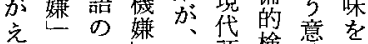

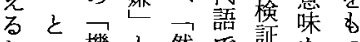
たい機と然で証をつ

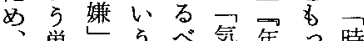
こ語と表き分報た宜 のが同現時の中こし

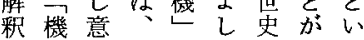

$\bigcirc$ 吉售判。 八家芯教月 条瓷示 三 永等德付 和応寺御 年四書御 七一三觛 
百 $\overparen{57}$ 期出家し八九学指奉 $\overparen{56}$ 五 $\widehat{55}$ く $\widehat{54}$ 候さ文さ $\widehat{53}$ る機ら伊

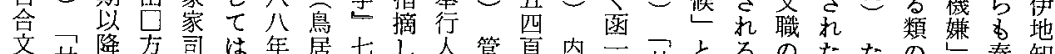

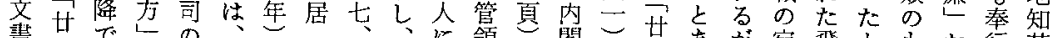
書 く古確重四室一村こは記可る。行驩竞のこ人に

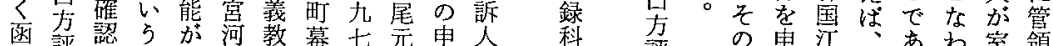

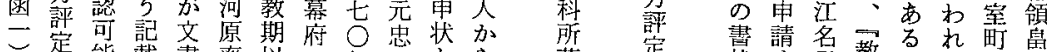

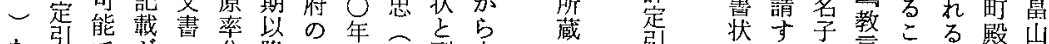
な付で加公降訴年村副申 它付古及支所治将尾状状 か応る

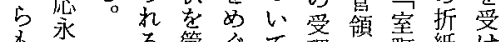
永方管くて理分盯紙

わ二 事領っ榆方職幕を取

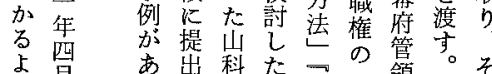

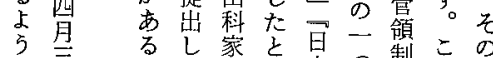

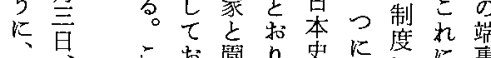

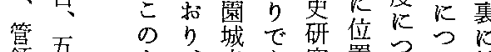

領吾少、寺あ究置いい鉝

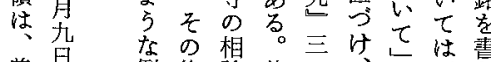

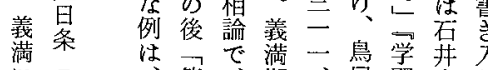

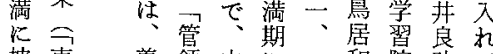

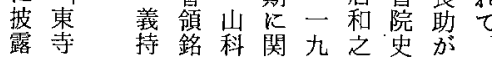

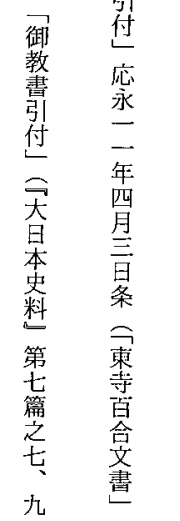

のる・言之披に基

来際松卿壱露対国

尾橋記示肪しへ

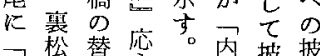

可㮔地永替露露

然光

事炕々年文挔依

者り閵二 5 云制

以な所 9 言なと

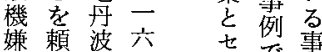

婕頼波六直学事

御た六条卜なで

沙書人にな゙なあ

汰桨部は使かる。

畏記錅押ささと

入载公妨的以占

59

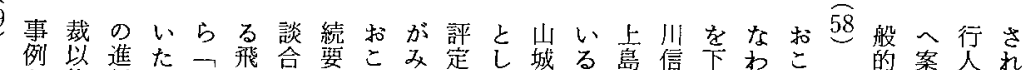

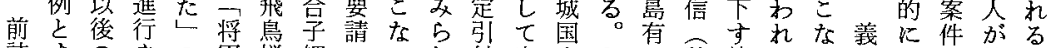

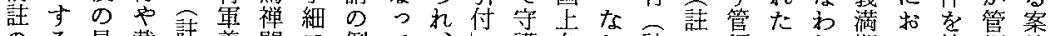
のる具戴註義門乃例て護久打註領これ期こ披領件 男忹体決 五持とルでい管空の世記 $\widehat{2}$ 奉とな以露のに

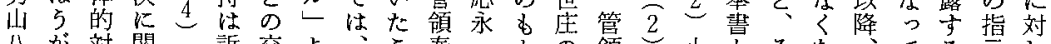
八が対関設訴交ょ淎

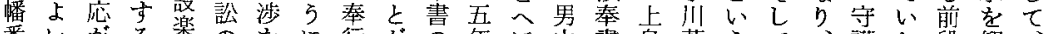

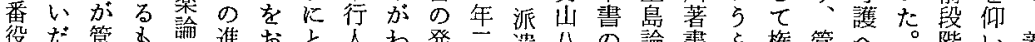

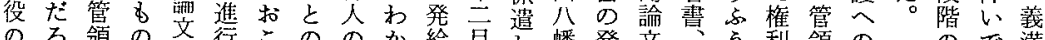

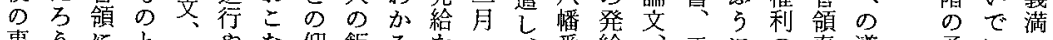

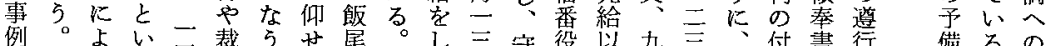

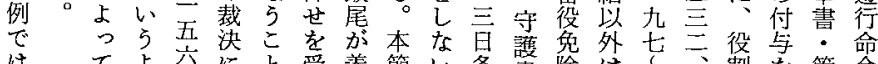

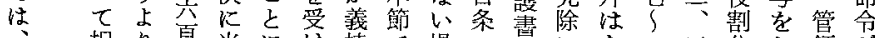

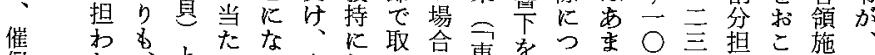

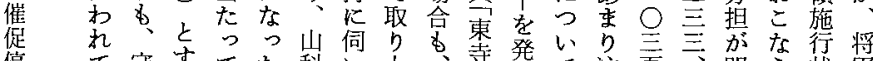

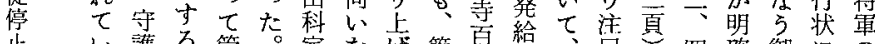

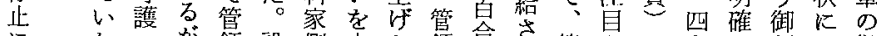

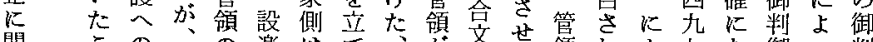

関このっの楽はて方齐せ領れよ七な御っ判

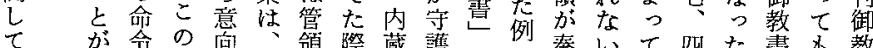

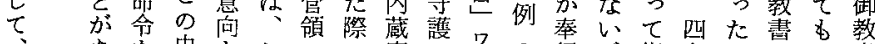

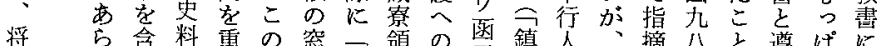

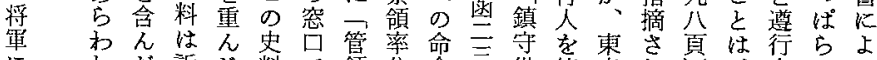

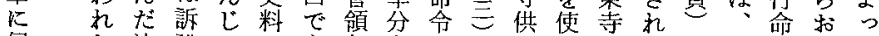

同た決㳂てかあ与存をこ僧者領てや小令こて草奨 


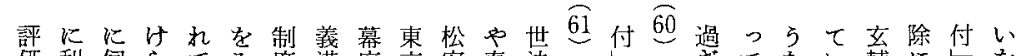

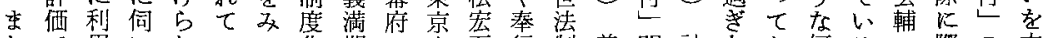
たで用いれいて化期の大至行制義明註な括何るに際今立

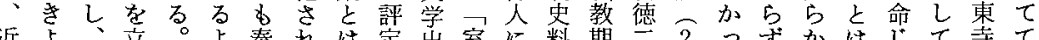

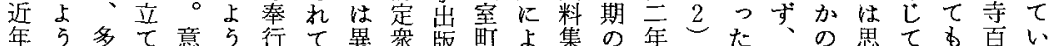

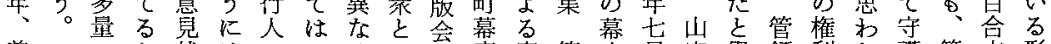

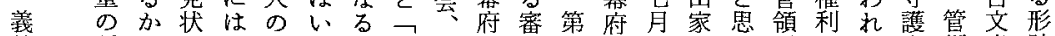

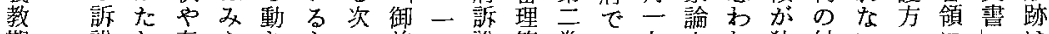
期訟 5 奉充きるの前九訟答巻は九文れ独付

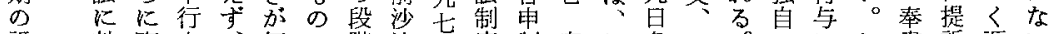

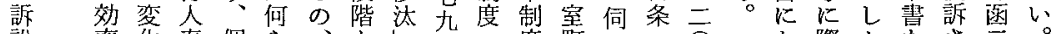
訟率化奉個 5 的意意幕年宣

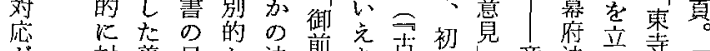

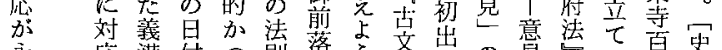

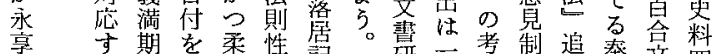

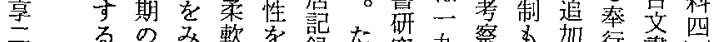

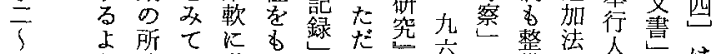

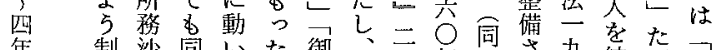

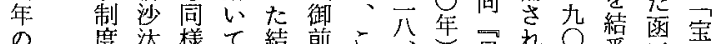

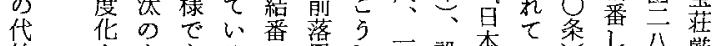

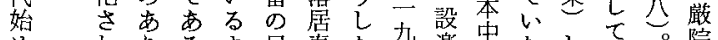

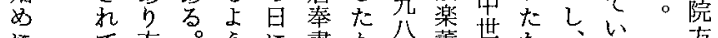

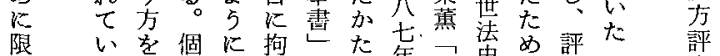

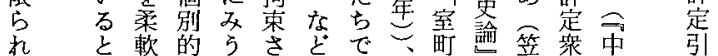

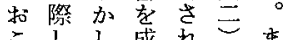
こL合成机主 いは御た後み 克、判占k交応

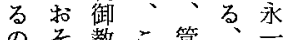
は方霉こ領山二 基々ので加城年 本管橆的東国 的領 給 将寺吉 には電淎野芰 僌独代飞行庄一 微自表伺での口 なにさいあ人方 事特れを者評 柄こ觉立斎役定

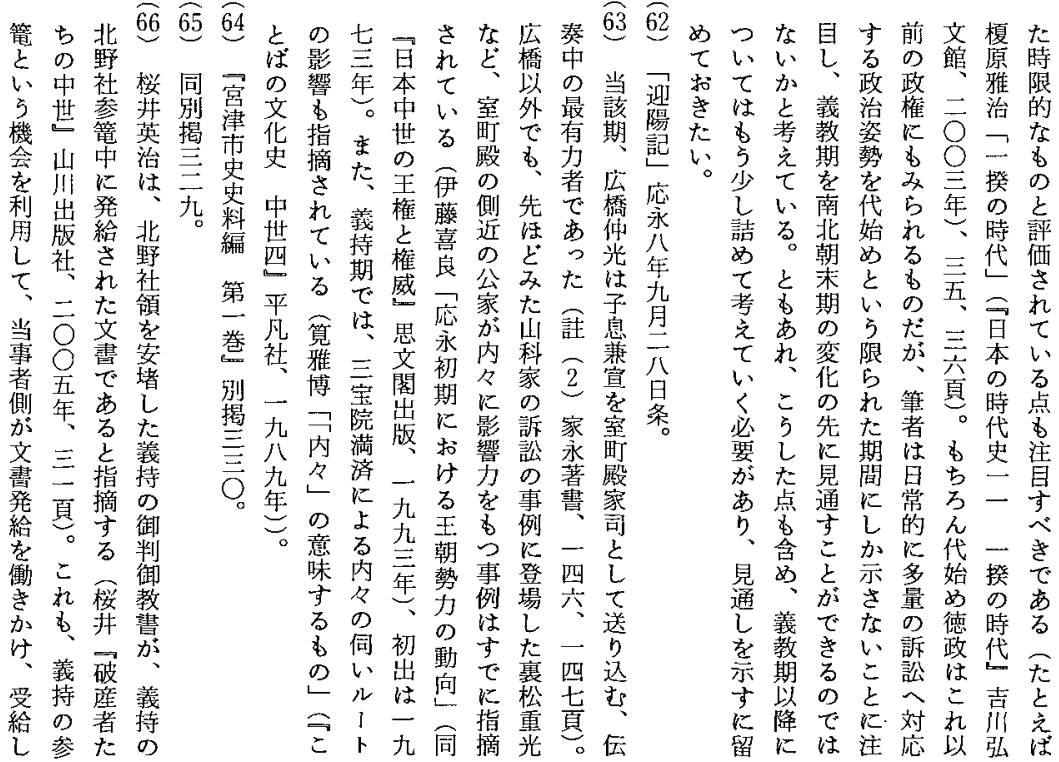




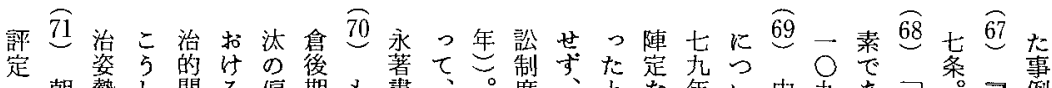

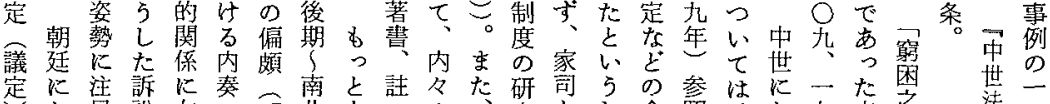

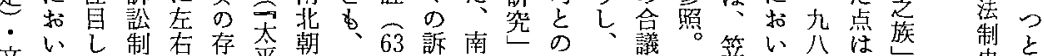

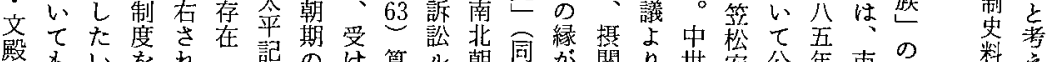

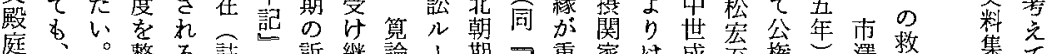

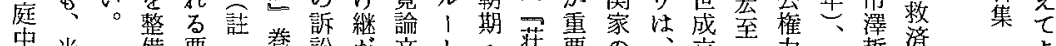

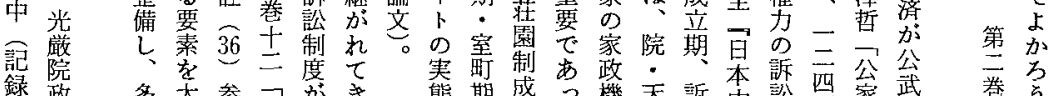

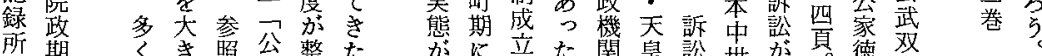

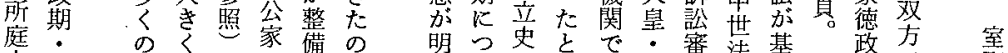

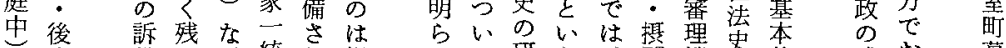

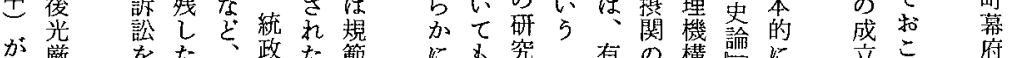

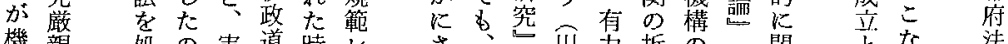

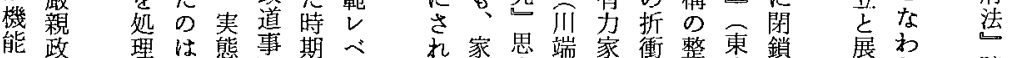

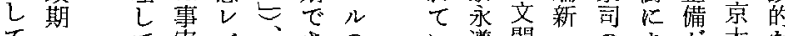

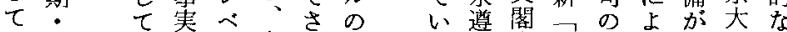

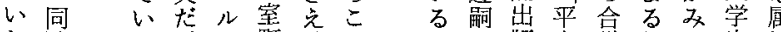

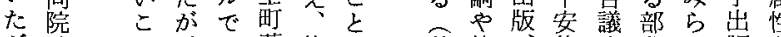

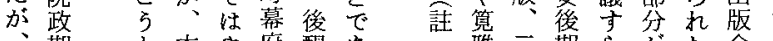

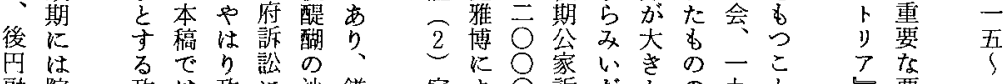

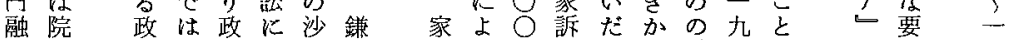

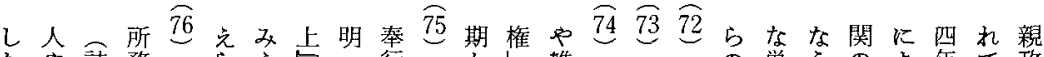

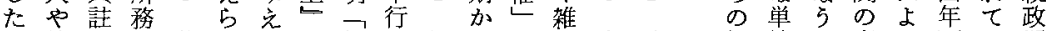
可管、沙幕れな思解人従ら秝訴本註中転純上衰り。い期 能領 2 汰府るく文説の来南㷊決稿 2 世換な 5 退説従る心

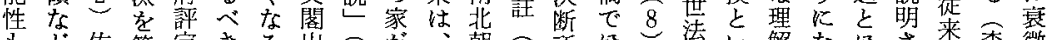

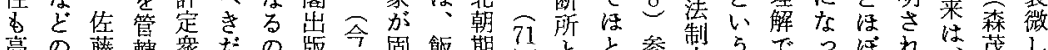

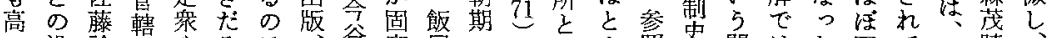

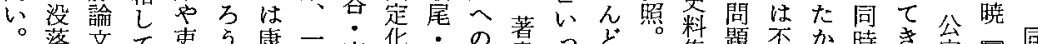

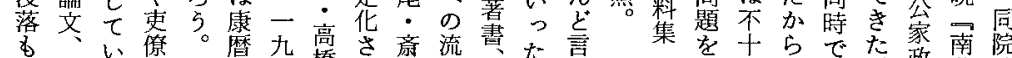

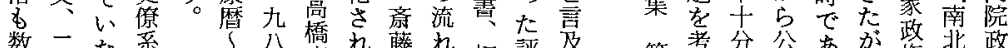
数二た亲々公橋机藤れ初評及第考分公あが政北政

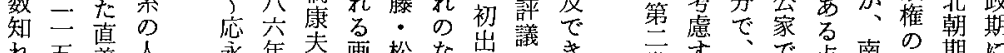

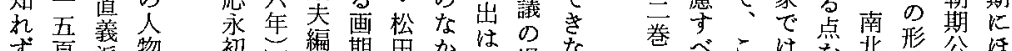

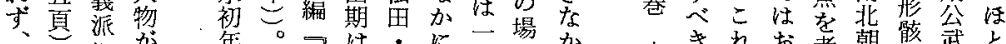

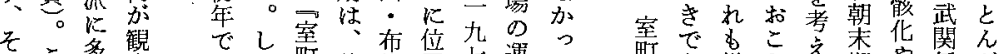

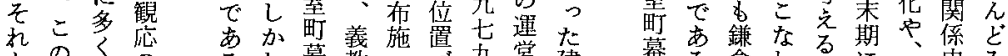

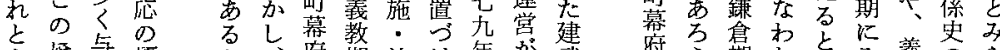

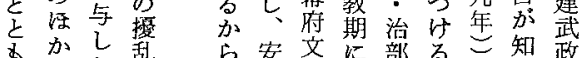

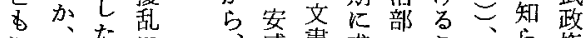

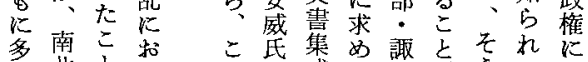

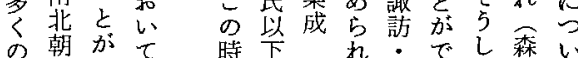

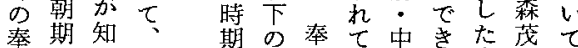

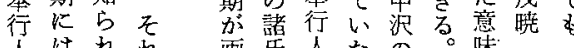

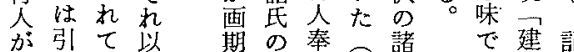
没付心前安家畫含氏 鐮武録

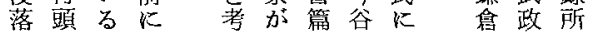

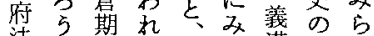
法。的な节满研 追一幕礼公究な

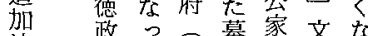
法的た室墓社南る 九机町の会出こ 政之殿所隻版々 治い一務出、怔 姿 5 王沙の一指 勢よ括汰影九摘 加亏こ機響八ざ 


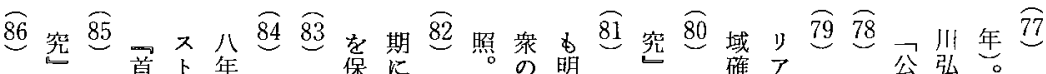

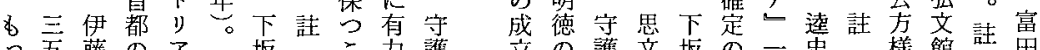

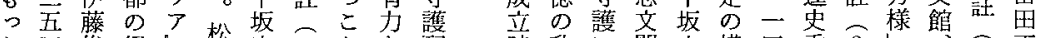

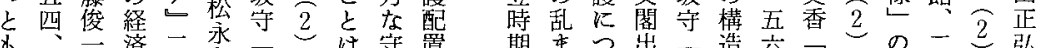

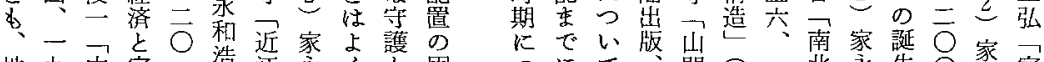

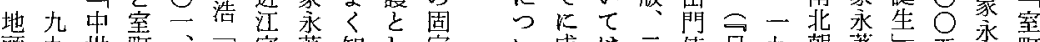

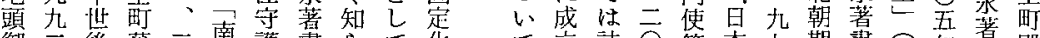

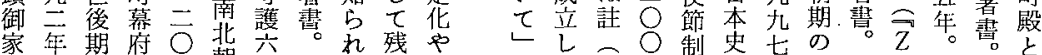

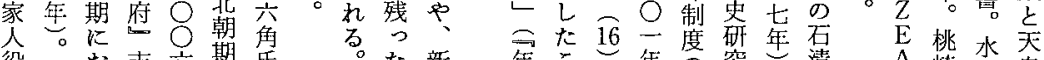

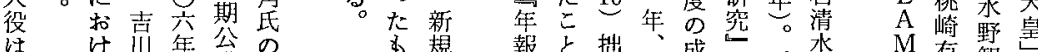

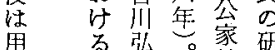

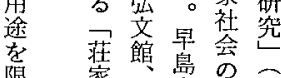

限家二突求舍

定文祐心草

出地公公造竟

所権年武充究

役忍。統害二

合政幕二

窒早諭府二

期軺同色卆

它 瞡

守

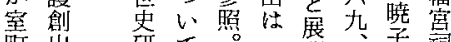

町出

時 の

代 隇

通少

通点

$\tau=$

注立

研七。二開子菏

究住㤗九开南家

I智智

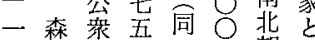

八萃吕年曻朝幕 美義年年期府

一定满箱。京政

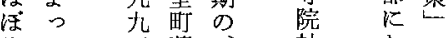

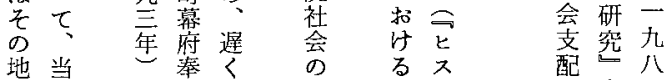

位就

参公之

四定本 一利 時 研

$\overline{0}$ 義代究 满公三 年公関一 。家係九 社 会研九 と吉九

○ $\widehat{91}$ 史 $\widehat{90}$ 五 $\widehat{89}$ 続家九 $\overparen{88}$ れ 正 $\bigcirc$ 至調含 $\widehat{87}$ 財年寺に

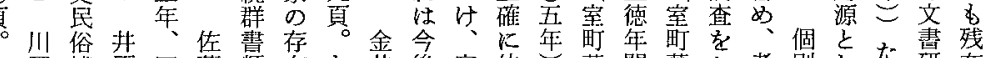

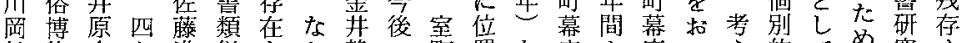

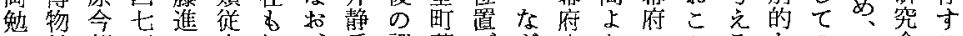
室研男

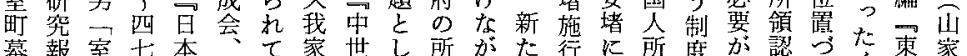

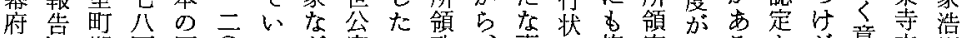

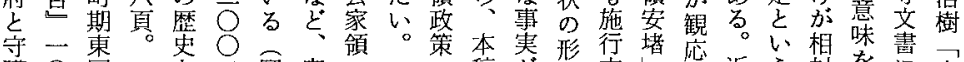
護○国杂 権四寺年野町研

力二社南南度殿究

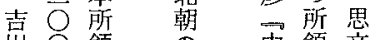

川 0 領 $の$ 中領 文

弘荘動世世閣

文年園乱资家出

館必手留版

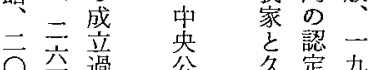

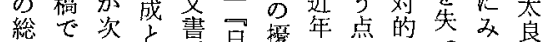

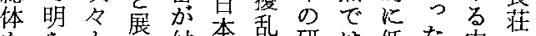

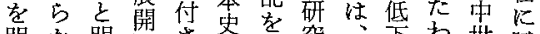

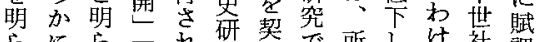

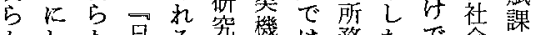

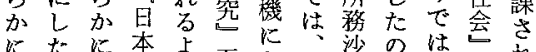

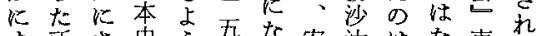
与哲さ史 5 吾な案汰はな東た

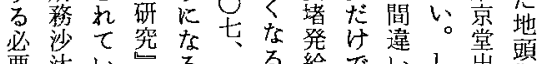

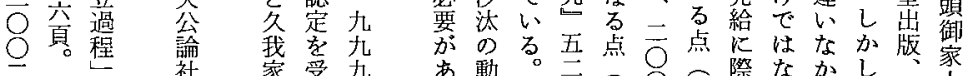
年司社家受䧱

一章无葆な二

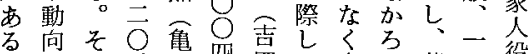

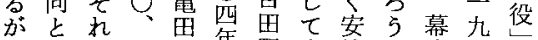

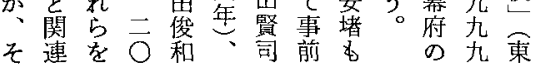




\section{【附表】【図 1】・【図 2】の出典}

・以下に,【図1】・【図2】のデータとして使用した文暂の出典を, その発給された日付とともに 示すそその際，刊行史料集は「』で表記し，史料(群)を示す場合などには適宜「」を使用した，

・南北朝䢙文』や自治体史のよ5K，買なる文書群の文書が混在する史料集では，文書群ごとに

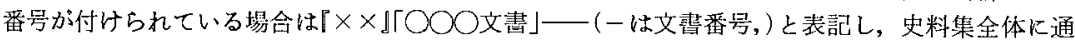
し番号が付けられているあのでは「 $\times \times \times 」 一$ (「OOO文畫」)と表記した。な拉，後者の場合， 数巻にわたる刊行史料集の全体に通し番号が付けられている埸合(『南北朝遺文」「大日本古文韭!な ど)は，適宜史料集の巻番号を省略している。

・「大日本古文甾」のシリーズは本来『大日本古文書 家わけメメ OOO文書」と表記すべきであ るが，適宜『高野迈』・石清水』・『㓋心寺』・毛利家』・『吉川家』・「小早川家』・『上杉家』・熊 谷・三浦・平賀家』・「山内首藤家』・『大德寺』・醍醐寺』・『東福寺」などと略称している.

・東寺関係の文畫については，次の略称を用いつつ，箱と文䝑番号を記した。「東寺」「東寺文 書」，「東百」=「東寺百合文畫」(それぞれ函名を適宜省略して記載した)。「東寺文書」「東寺瑟宝蔵 中世文書」阿刀文書」は京都府立総合資料館の写真帳，「東寺百合文書」绀同所と京都大学古文書案 両所の写真䐘を使用して確認した。

・「東大步文書」「東大寺宝庫文昌」については，京都大学古文書室の写真帳で確認し，「東大寺文書 目録』の番号に従って記載した。

・「醍醐寺文書」については，大日本古文書で刊行されている文甾はその番号によって記載し，末

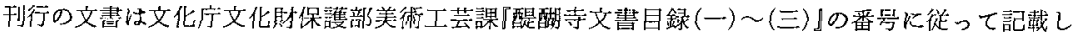
た。写真帳は，京都府立総合史料館のものを使用した。

・「天竜寺文書」については，京都府教育委員会「天竜寺古文書目録』の番号に従って記載した，写 真帳は京都腑立総合史料館のものを使用した。

・「尊経閣古文書篓」については，東京大学史料編筑所所蔵の写真帳で碓認した。

・そのほか, 筆者が京都大学吉文書室所蔵の影写本(謄与本, 写真帳)で確認した場合は「京大影写 本」(「京大鰧写本」，「京大写真艮」），東京大学史料編纂所所蔵の影写本(写真帳)で確認した場合は 「東大影写本」(「東大写真帳」) と注記した。

-『八坟』=「八圾神社文書』, 「長福寺』=『長福寺文書の研究」, 『壬生家』=「壬生家文書】, 『九条

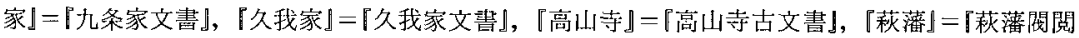
録』, 『南禅寺』二『南禅寺文書』，『松尾】=『松尾大社史料集 文書篇】、『金岡三昧院』二「高野山文 書 第五巻 金風三昧院文書」，「妙法院」=「妙法院史料 古記録・古文書」，『佐々木』二『戦国大 名尼子氏の伝えた文昌 佐々木文書】, 『宗像」=『宗像大社文書』, 『猪熊』=『広島大学所蔵猪熊文 蟙】

・県史はそれぞれ県名と史(資)料編中世(ないしは「古代中編」)の巻号のみを略記する。

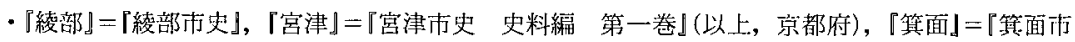
史」，「島本」=『島本町史』，『高石』=『高石市史』(以上，大阪府）「水口』=『水口市志】(以上，淡 賀県)

-『南北中四』=「南北朝遺文中国四国編」，「南北九州』=「南北朝遺文九州編』

・『大日史」=「大日本史料】，とくに注記しない場合は同日条.

・「細川家文書」は「熊本県文化財調查報告第二十三集 古文書等緊急調查報告書 細川家文書(中 世篇)』を参照.

\section{○引付頭人奉書の典拠}

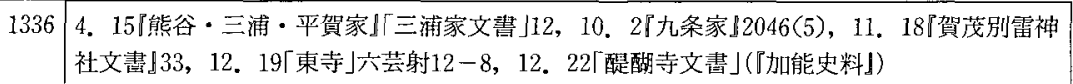


室町幕府所務沙汰とその离㗨

1337

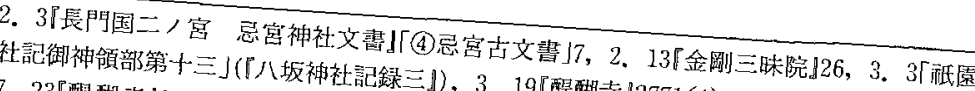

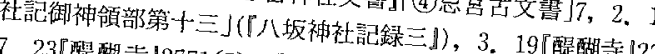

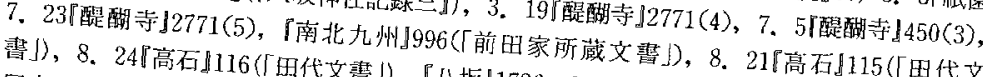

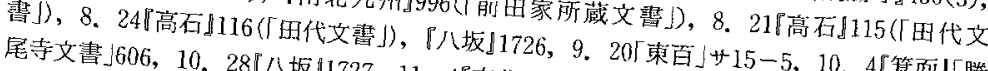

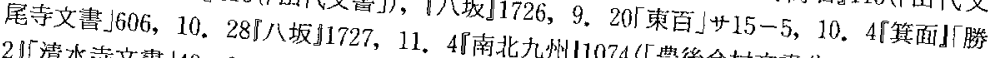

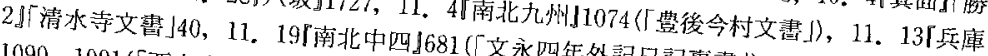
1090，1091(「西大寺文書」)

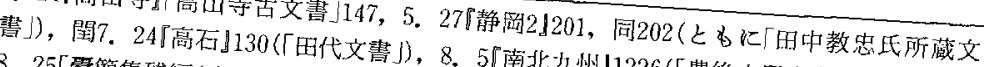

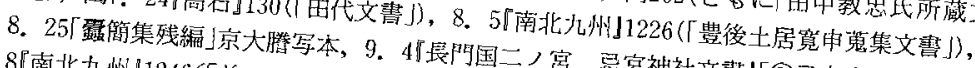

8『南北九州11246(前时家所藏文書】)

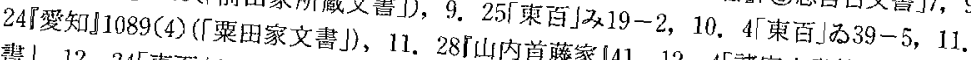

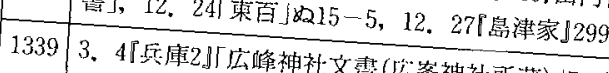

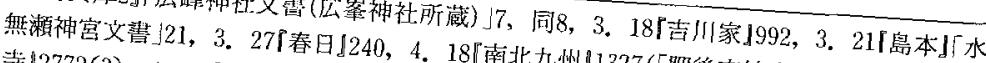

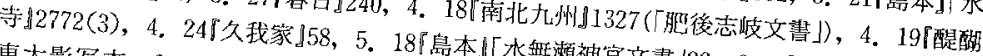

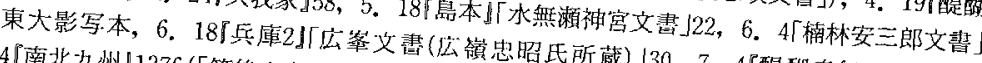

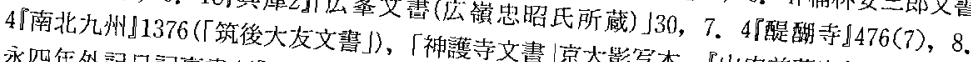

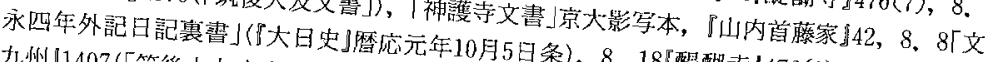

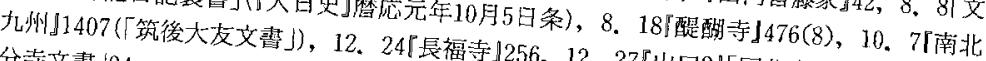
分寺文甾 194

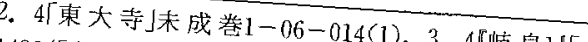

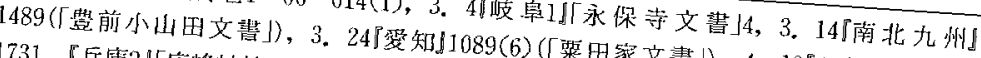

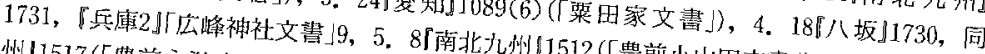

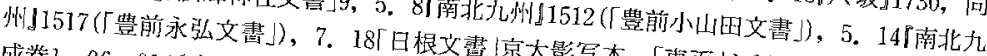

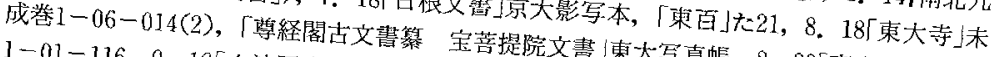

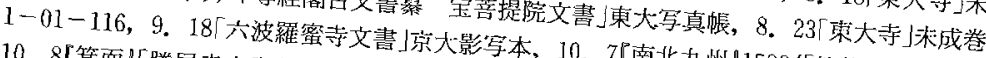

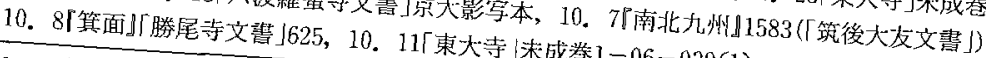

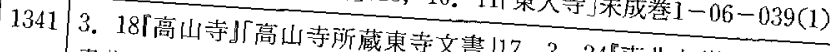

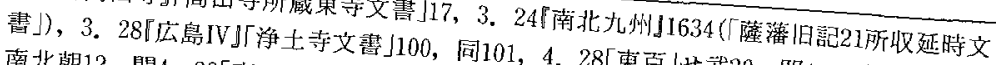

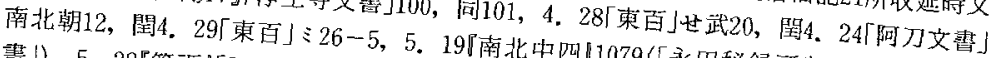

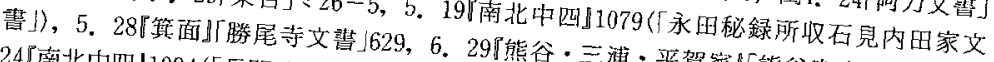

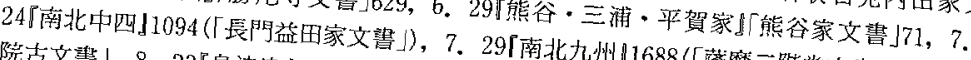

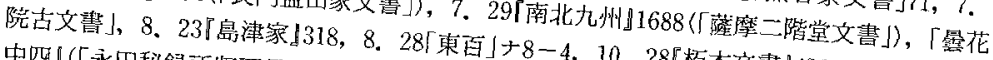

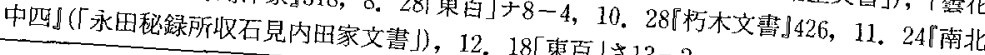

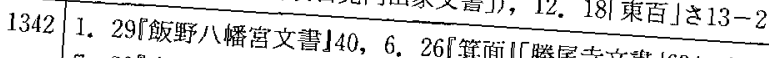

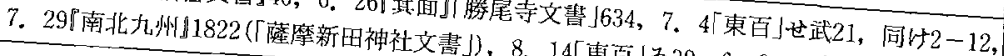

1343 3.4「新潟」1047(色部文書」)，3

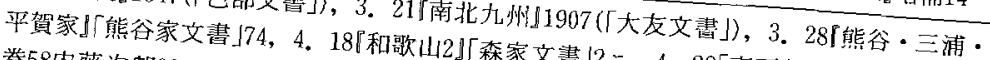

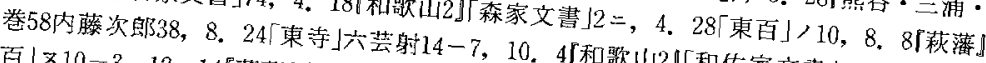

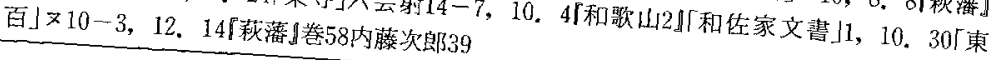




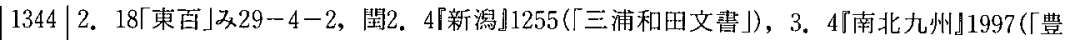
前永弘文書」)，6，6「南北九州!2020(「宇佐郡諸家古文書六所収 北正樹文書)，7．4「福 島」42(「秋田藩採集文書 岡本文書」)，10．18「東百」せ $12 ， 229-2-3 ， 11 ， 28$ 「醍醐寺 17 , 12. 8 「東百」术 23

13456 6. 8 「南北九州」2117(豊前永弘文書」)，6. 18「南北九州』2119(「豊前永弘文書」)，10。 18「東寺」六芸射14-8, 「桂文書」(東大影写本)，『南北中四』1429(「尊経閣占文書策 宝蓄 提院文書」)，10.28「兵庫2」「内藤文畫」2，11．4「市島謙吉氏所蔵文書」東大影写本，11. 8 南北九州】2152(「豊前永弘文書」)，11，18『南北九州』2158(「筑後大友文車」)

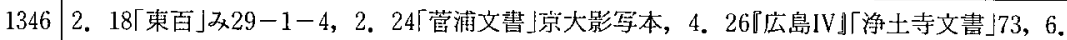

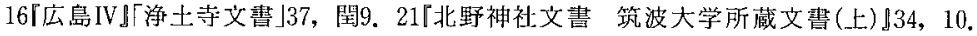
18「新興寺文韭」東大影写本，11．8『南北九州』2264(「善法寺文書」)，12．14「尊経閣古文書 管宝萻提院文書」

1347 3. 28『南北九州』2316(「橘中村文畫」)，5，14『醍醐寺』9，7，4「東百」け2-17，8．8「大徳

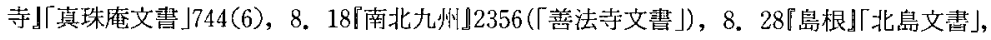
『醍醐寺』10，9．4『熊谷・三浦・平賀家】熊谷家文曺」86，12．4「東百」け2-18

1348 8. 21「南北中四』1661 (「法観寺文書」)，9．4【新潟」2333(「高橋六之助氏所蔵文書」)，9. 14南北中四』1667 (「井原家文畫」)，10．8「東百」を9

1349 2. 4「東百」汪36-3，，2．25「尊経閣文庫所蔵文書」東大影写本，2．29「南北九州12577(「武 家雲嘎所収文畵」)，3．14「高野山】「又続宝簢集」1964，3，28「華頂要略門主伝補遺」，4. 4 「東大寺」未成巻 $1-12-090 ， 6$. 4「東百」せ武 24 , 同 25 ，「菅浦文畫」京大影写本，6.

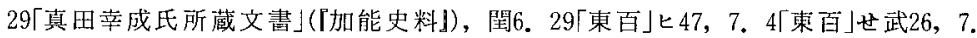
25「八坂】1642，12. 24「東百」せ武27，同末25，『高山寺「高山寺所蔵東寺文書」21

1350 3. 4「東百」世武28，3．8「東百」ひ14-24，3．28「兵庫8』「広橋家文書」14，4．12「新潟』 1295，1297(ともに「三浦和田文畫」)，5，3『長福寺」373，5，24「東百」る27-11，9．10「兵 庫9』「加藤藤围氏所蔵文畵」1，9．24『壬生家』2506，9．25「尊経閣文庫所蔵文㶳」東大影写 本

1351 3. 24 「兵庫8 「「広橋家文書」18，3．25「二尊院文書」東大影写本，4．1[醍醐寺』1259, 「醍醐 寺文書」21圂116，「東王」/17，4，9「熊谷・三浦・平賀家】平賀家文書」136，4，11「仁和 寺文書」京大影写本，4．13「長福寺』390，4．19「中村文畫」東大影写本 (二通)，4．21「松

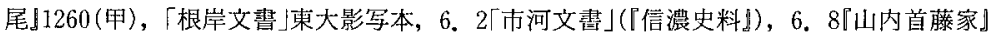

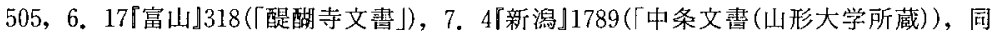
2334 (「高橋六之助氏所藏文書」)，9.28「盧山寺文書」東大影写本

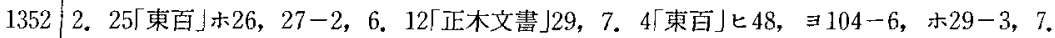
27『島津家』308，8．5「東百」そ13-4，9，12「壬生家」600，10．3「松雲公採集遺編類籍150 雑文書」，11．4「東百」 $>50-5 ， 11$ ．18「東百」ミ28-2, 同28-3，11．22「宗像2」「出光佐 三氏奉納文書 $\ 23$, 同「近藤清在写本宗像文書」12，12．14「醍醐寺』481，12．18「久我家」 $105(3)$, (4)

1353 2. 18「久我家」105(5)，2．28「久我家』105(6)，「祇園社記御神領部第五」(「八坂神社記録 三』，3．4「八坂』1739，9．2「臨川寺重晴案文」，9．14「東百」二38，10．17「若王子文書」 京大影写本, 10. 19「早稲田大学所藏(荻野研究室収集)文暂』139(「祇園社文暂」), 12. 22「東百」る $30-1 ， 12$ ，23「長福寺』428, 「広島IV】「鼓文書」10，12．24「臨川寺重書案文」, 
室町幕府所務沙汰とその変質

\begin{tabular}{|c|c|}
\hline 1354 & 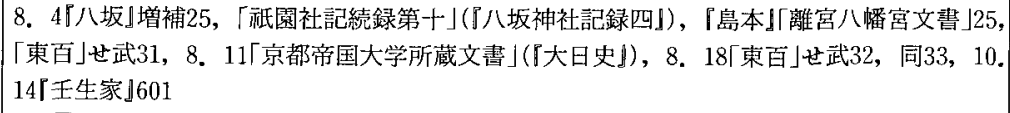 \\
\hline 1355 & 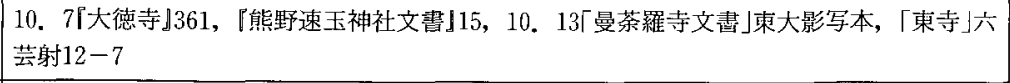 \\
\hline 1356 & 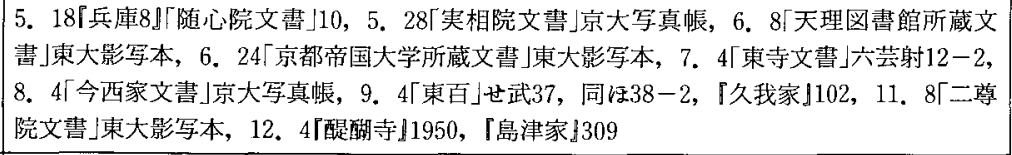 \\
\hline 1357 & 4. 8 「輯古帖」9-39(『三重1下』)，6．8「斎藤文䓙」東大影写本，6．18「醍醐寺』1950 \\
\hline & - $\cdots$ \\
\hline 1363 & 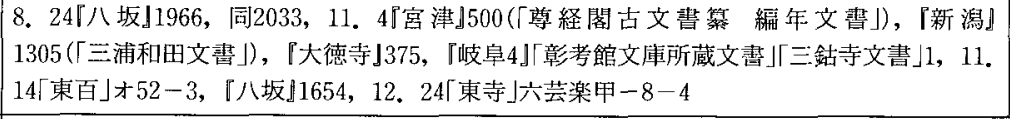 \\
\hline 1364 & 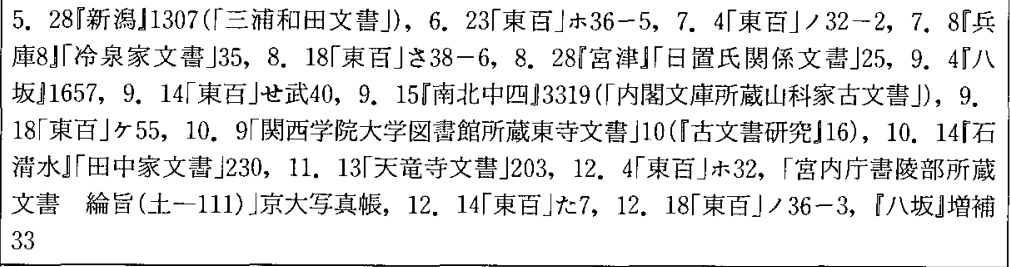 \\
\hline 1365 & 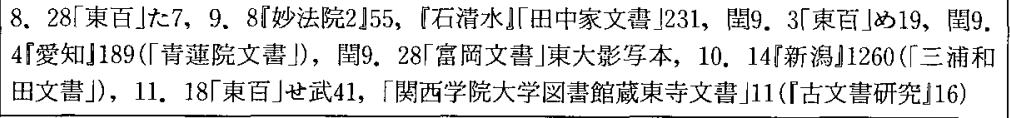 \\
\hline 1366 & 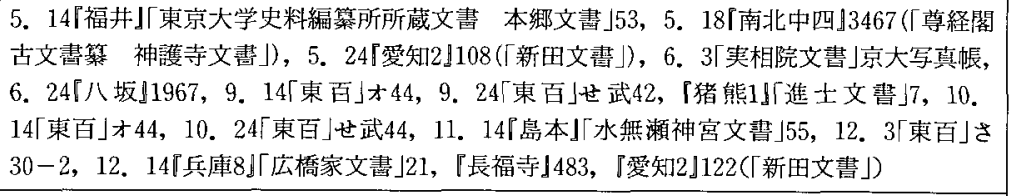 \\
\hline 1367 & 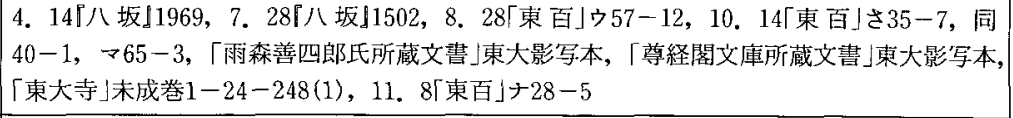 \\
\hline 1368 & 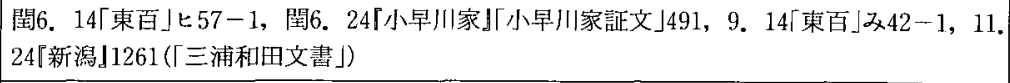 \\
\hline 1369 & $\begin{array}{l}\text { 6. } 8 \text { 『亀岡』1462(「出雲神社文畵」)，9．24「亀田輝時氏所藏文書」(『大日史』)，11．3「阿刀 } \\
\text { 文書」南北朝59 }\end{array}$ \\
\hline 370 & 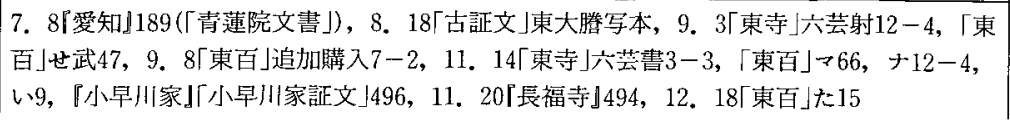 \\
\hline
\end{tabular}




\begin{tabular}{|c|c|}
\hline 1371 & 4. 3「東百」た $15 ， 12.15\lceil$ 祇園社記続録 第九」(「八坂神社記録四』) \\
\hline 1372 & 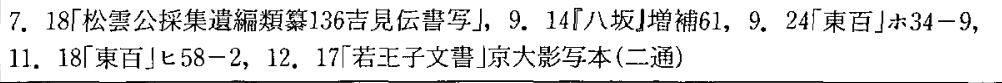 \\
\hline 1373 & 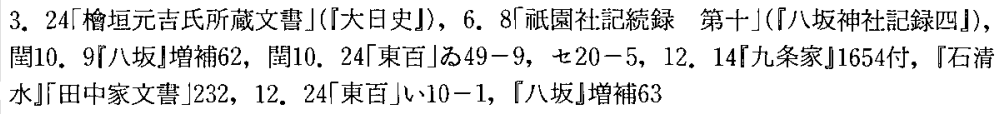 \\
\hline 1374 & 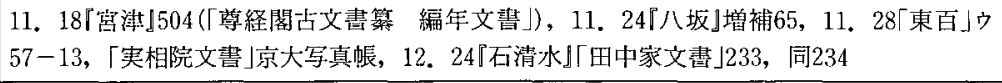 \\
\hline 1375 & 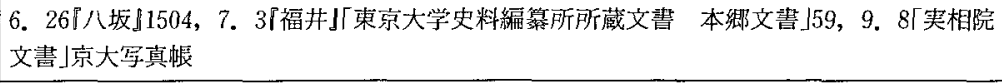 \\
\hline 1376 & $\begin{array}{l}\text { 4. 25「東百」/64，11．14「南北中四』4318(「尊経閣古文書纂 神護寺文畫」)，11．24「美吉 } \\
\text { 文書」, 11. 29「広井文書」東大影写本 }\end{array}$ \\
\hline 1377 & 8. 24「若王子文書」京大影写本, 12. 15 「広井文書」東大影写本 \\
\hline \multirow[t]{2}{*}{1378} & 9. 20 「九条家』1656，12，17「東百」七60-1 \\
\hline & $\cdots$ \\
\hline 1381 & 5. 10『小早川家』「小早川家㼗文 $」 500$ \\
\hline \multirow[t]{2}{*}{1382} & 12. 25 「東百」ヤ37 \\
\hline & $\cdots$ \\
\hline 1391 & 8. 11『壬生家』704 \\
\hline 1392 & 12. 23「壬生家』58 \\
\hline 1393 & 9. 6 『長福寺】652 \\
\hline
\end{tabular}

\section{御判御教書の典拠}

1351 6. 17『高野山」「又続宝簡集」1968，「河野家文書」31，『八坂』1662，6．19「尊経閣文庫所蔵 文書」東大影写本，8．13「神護寺文書」京大影写本，9．8「天竜寺文書」107，10，17『醍醐

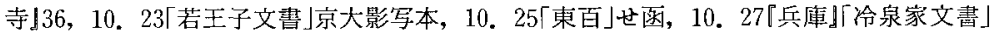
34，『岐皁4』「京都大学所蔵文書 古文書纂」2，『宮津』「西大寺文書」291，11．2「総持寺文 書」東大影写本，「兵庫1」「井上泰輔氏所蔵文畫」2，11．3「金沢文庫古文書」5221，11．6 「醍 醐寺 339，11，10个綾部』「丹波安国寺文畫」19，12．1「吉田默氏所蔵文書」東大影写本，「東 百」ひ21 (二通)，11．25「入江文書】21，12．10「宮内预書陵部所蔵文書 足利義詮・細川清 氏消息 (谷一 420 ) 京大写真帳

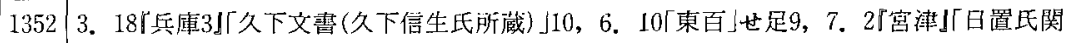
係文昦」13，7．24「久我家』88，同89，7．27「中院文書」東大影写本，「妙心寺文書」京大影 写本, 「妙法院2」54, 「若王寺文書」京大影写本，8．2「大賀文書」京大影写本，『東福寺』 $412(5) ， 8$ ，3「勧修寺文畫」東大滕写本，8．5「二學院文書」東大影写本，8．8「東百」せ足 10 , 「長福寺」407, 「北野社家日記7』「目安申状」文龟二年，8，11『箕面』「勝尾寺文畕」668, 「醍 醐寺】1951，8．20「锄修寺文書」東大滕写本，8，21「東百」世足11, 「東寺䇛宝蔵中世文書」 $3-5$,『壬生家』328，8，24「実相院文書」京大写真帳，「祇園社記 御神領部 第十一」，8. 


\begin{tabular}{|c|c|}
\hline & 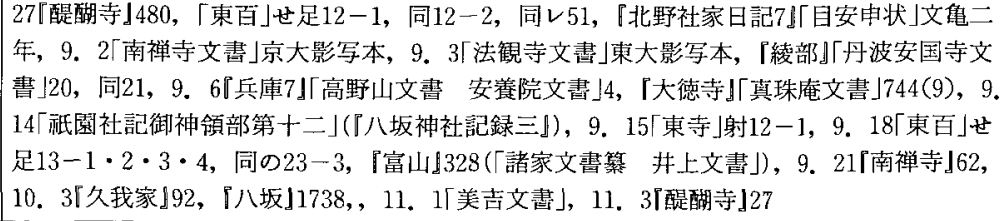 \\
\hline 1353 & 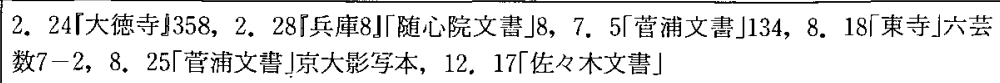 \\
\hline 1354 & 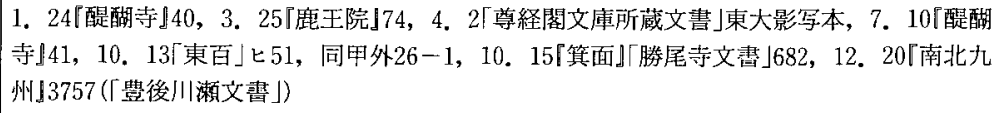 \\
\hline 1355 & 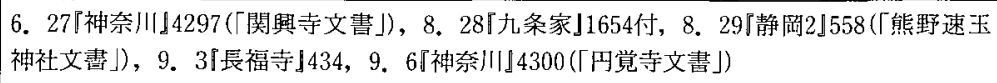 \\
\hline 1356 & 9. 13 「䠉浦」144 \\
\hline 1357 & 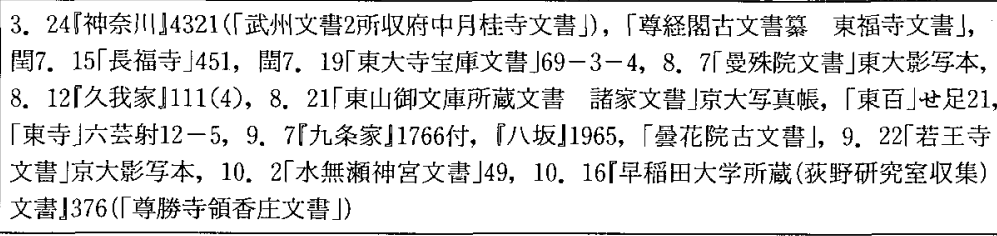 \\
\hline 1358 & 3. 26 「大徳寺」375，11. 16「中村直勝氏所藏文畫』69 \\
\hline 1359 & 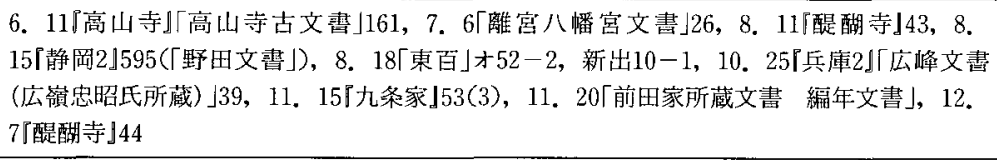 \\
\hline 1360 & 3. 4 『大徳寺』 $375 ， 3 ， 12\lceil$ 東文畫」(『大日史』)，8，28『入江文書 $₫ 47$ \\
\hline \multirow[t]{2}{*}{1361} & $\begin{array}{l}\text { 6. 9『松尾』1573(二通)，10. 3「中院文書」東大影写本，11．20「尊経閣古文書箱 神護寺文 } \\
\text { 昌」 }\end{array}$ \\
\hline & $\cdots$ \\
\hline 1363 & 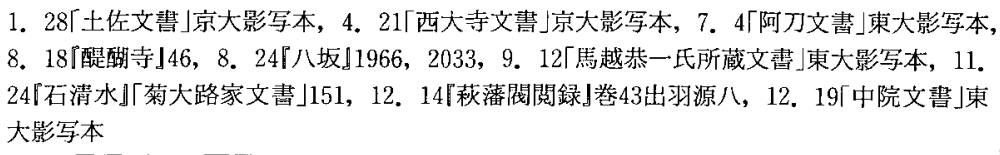 \\
\hline 1364 & 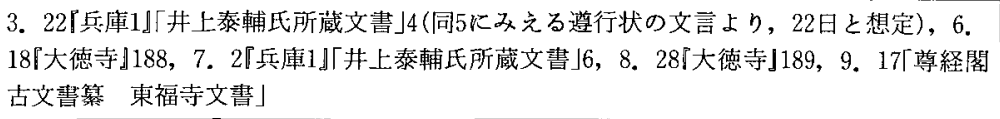 \\
\hline 1365 & 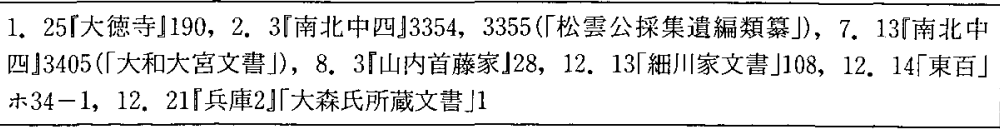 \\
\hline
\end{tabular}




\begin{tabular}{|c|c|}
\hline 1366 & 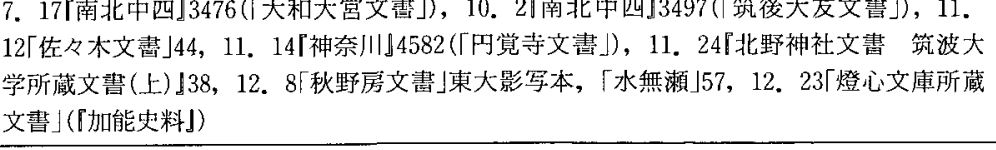 \\
\hline \multirow[t]{2}{*}{1367} & 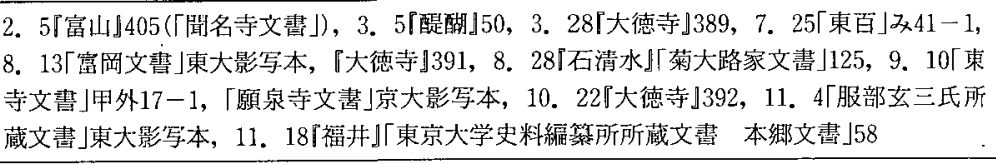 \\
\hline & $\cdots$ \\
\hline \multirow[t]{2}{*}{1379} & 5. 6「美吉文畫」, 5. 28「富山』474 \\
\hline & $\cdots$ \\
\hline \multirow[t]{2}{*}{1385} & 11. 13 厅八坂』1327 \\
\hline & $\cdots$ \\
\hline \multirow[t]{2}{*}{1390} & $\begin{array}{l}\text { 7. } 12\lceil\text { 南北中四』5277 (「美吉文書」)，8．3【南北九州』6135(「肥後詫摩文書」)，9．21「若王 } \\
\text { 子文甾」京大影写本 }\end{array}$ \\
\hline & $\cdots$ \\
\hline 1395 & 1. 11 「歓修寺文書」東大腃写本 \\
\hline \multirow[t]{2}{*}{1396} & 10. 11 「醍醐寺』1978，11．14『醍酤寺」1824 \\
\hline & $\cdots$ \\
\hline \multirow[t]{2}{*}{1398} & 閏4. 28『醍醐寺』74 \\
\hline & $\cdots$ \\
\hline 1400 & 4. 28 「石清水』「菊大路家文書」132 \\
\hline 1401 & 6. 11 「小代文書」43 \\
\hline
\end{tabular}

\section{-下知状の典拠}

\begin{tabular}{|c|c|}
\hline 1351 & 6. 19 「久我』82 \\
\hline \multirow[t]{2}{*}{1352} & 9. $11\lceil$ 東百」= $=18-7$ \\
\hline & $\ldots$ \\
\hline \multirow[t]{2}{*}{1370} & 12. 27『南北中四】3835(「尊経閣古文書箘 青蓮院文書」) \\
\hline & $\cdots$ \\
\hline \multirow[t]{2}{*}{1373} & 7. 19 【小早川家』「小早川家証文 $\rfloor 497$ \\
\hline & $\cdots$ \\
\hline \multirow[t]{2}{*}{1377} & 12. 21 『朽林』5 \\
\hline & $\cdots$ \\
\hline 1381 & 12. 27 「石清水」「㐘大路家文書」157 \\
\hline
\end{tabular}


窒町幕府所務沙汰とその変質

\begin{tabular}{|c|c|}
\hline 1385 & 8. 6「祇園社記御神領部」第四 \\
\hline 1386 & 6. 12〔八坆』1509 \\
\hline \multirow[t]{2}{*}{1387} & 12. 23『大徳寺』195 \\
\hline & $\cdots$ \\
\hline \multirow[t]{2}{*}{1390} & 6. 21 「北野社家記録」(『扣能史料』) \\
\hline & $\ldots$ \\
\hline 1401 & 10. 28 「東寺」千字文13宿 \\
\hline
\end{tabular}

\section{○執事・管領奉書の典拠}

\begin{tabular}{|c|c|}
\hline 1360 & 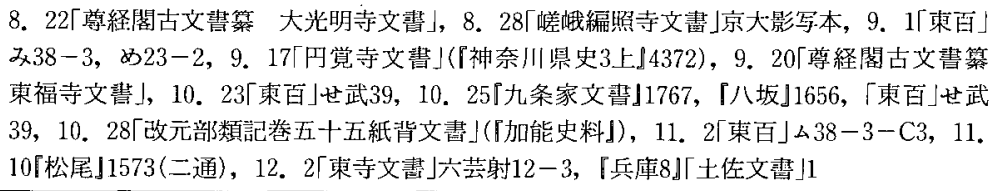 \\
\hline & $\cdots$ \\
\hline 1363 & 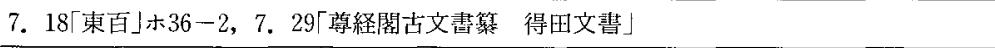 \\
\hline & $\ldots$ \\
\hline 1368 & $\begin{array}{l}\text { 閏6. 12「秋元興朝氏所藏文書」(「大日史」)，8．6「祇園社記御神領部第十二」(『八坂神社記 } \\
\text { 録三」)，10.7「東百」せ20-2，12.29『小早川家」「小早川家證文 }\rfloor 494\end{array}$ \\
\hline 1369 & 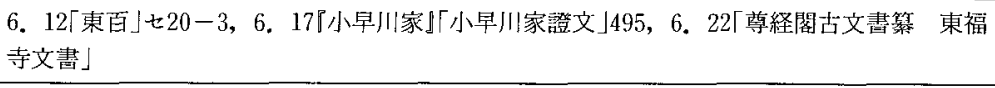 \\
\hline 1370 & 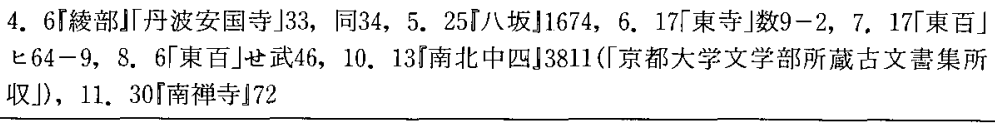 \\
\hline 1371 & 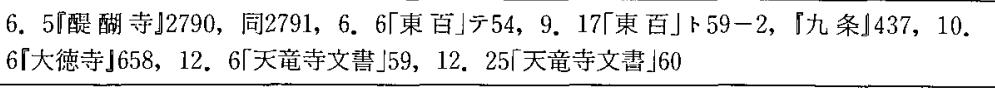 \\
\hline 1372 & 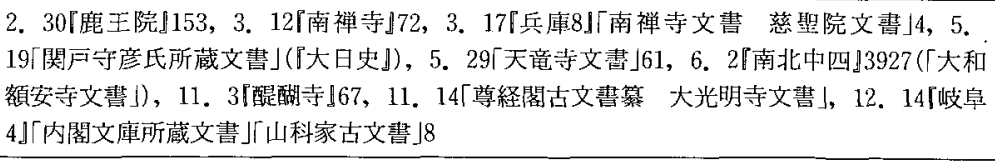 \\
\hline 1373 & 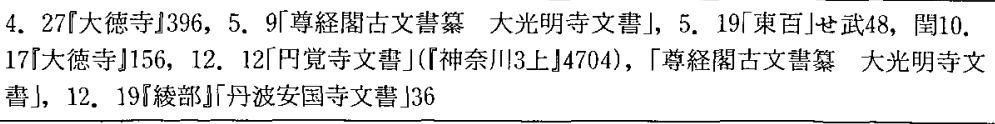 \\
\hline 1374 & 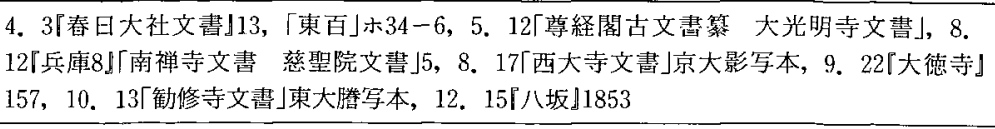 \\
\hline
\end{tabular}




\begin{tabular}{|c|c|}
\hline & 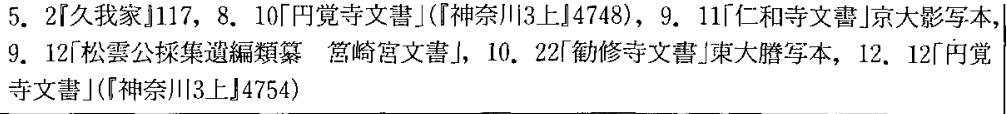 \\
\hline 1376 & 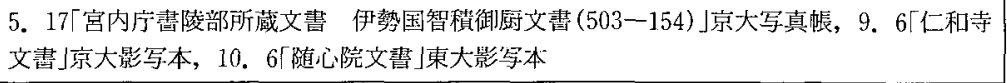 \\
\hline 1377 & 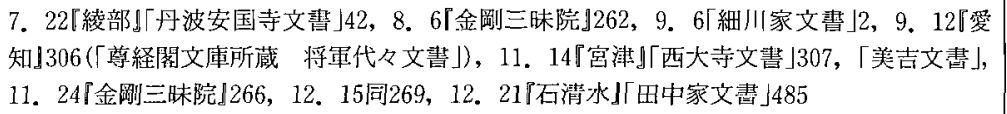 \\
\hline 1378 & 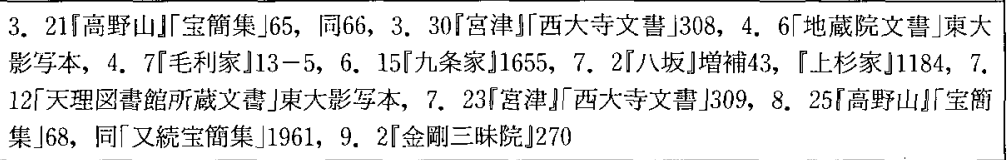 \\
\hline 1379 & 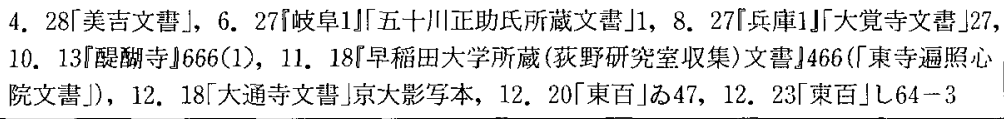 \\
\hline 1380 & 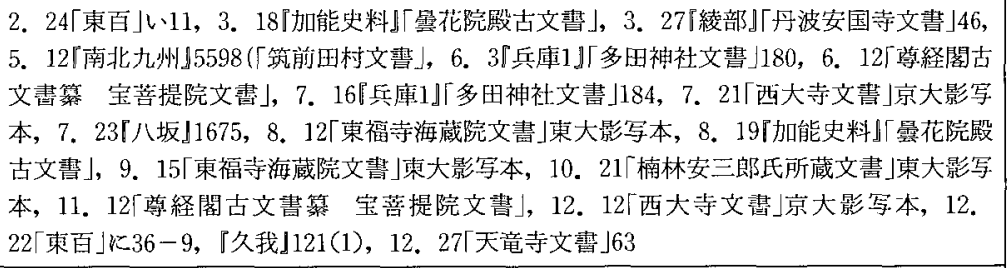 \\
\hline 1381 & 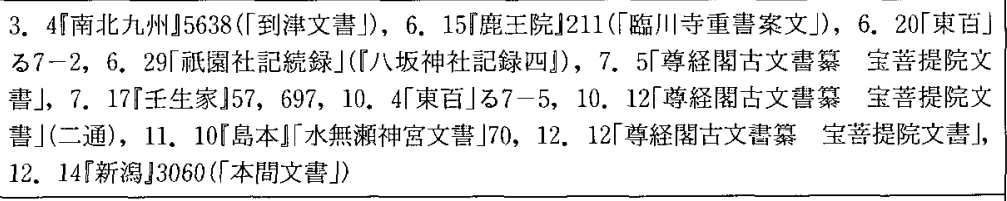 \\
\hline 1382 & 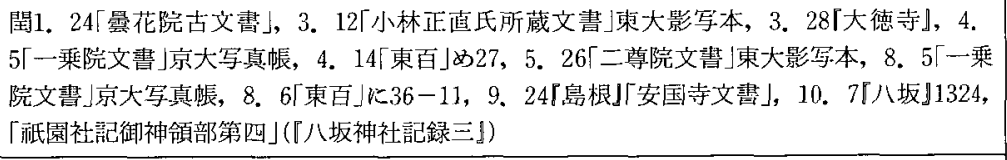 \\
\hline 1383 & 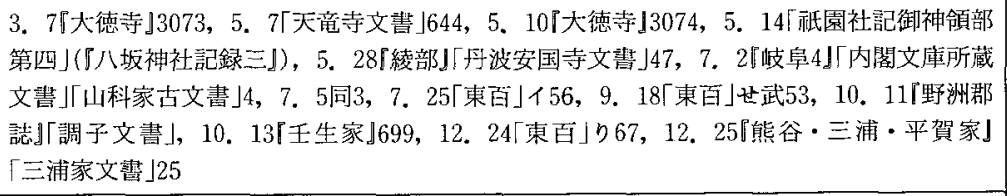 \\
\hline 1384 & 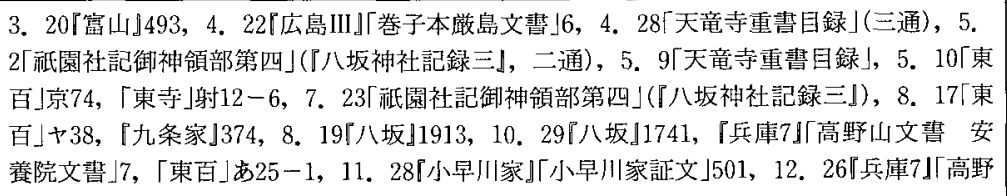 \\
\hline
\end{tabular}




\section{室町幕府所務沙汰とその変質}

\section{4 山文書 安養院文暮」8}

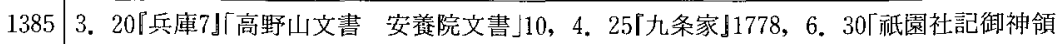
部第十」(「八坂神社記録三』)，7．7「長福寺』591，「東百 」t 39 , 同才 74，7．8「兵庫7』「高野 山文書 安養院文琵」12，7．24「祇園社記続録第十」(【八坂神社記録四】)，『八坂』1742，8. 25「九条家』1664，「富山』497(「南禅寺文書」)，10．14「東百」ヤ40，同75，10．29「東百」や 武 58 , 「東寺」数 $10-13$

1386 3．6『八坂』1917，3，12「南北九州15958(「碩田叢史所収田原文書」)，3．14『八坂』1743，3. 21「南北九州」5960(「豊後草野文書」)，6．5「八坂」1329，6．7「壬生家」187，6．27「富田仙 助氏所蔵文書」東大影军本，7．12「八坂』1509，8．7「東百」ア97-8，8．29「東百」來36－6, 9. 6 【八坂』 1330

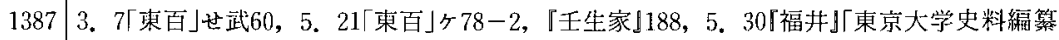

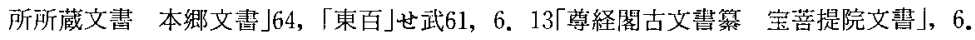
20 「大徳寺」398，6，29「禁寺」射 $1-2 ， 7$ ，21「東百」才 $78 ， 8$ ，4「東百」36-8，8，6「富山』 502 (後鑑所収文畵」)，8．21「実相院文暂」京大写真帳，9.6猪熊1〕進士文書」14，10. 11「東百」オ79，11。7長福寺」604，11. 29『長福寺」607, 同608，12，26「長福寺」609, 同 $610 ， 12.29\lceil$ 実相院文畫」京大写真艮

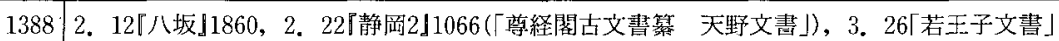
京大影写本，4.8「静岡2」1075(「尊経閣古文昌纂 天野文書」)，5．20「祇園社記御神領部 第四」(「八坂神社記録三】)，5．25「円覚寺文書」(『神奈川3上」5038)，6．7『南北九州』 6059 (「豊後草野文書」)，6.21「東百」ケ78-1，8．21「西山地蔵院文書」京大写真帳，『静岡

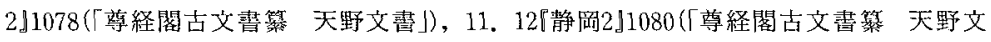
書」)，11。25「醍醐寺文畫」21函90，12．12『八坂』1919，12．14「祇園社記続録第十」(『八坂 神社記録四』)，12．17『長福寺』617，12．30「试園社記続録第五」(厂八坂神社記録四』）

1389 4. 13 「実相院文畫」京大写真帳，6．15「広島III「巻子本厳島文畫」7，6．17「䁌阜4」「山科家 古文書」13，「醍醐寺文書」21函88，7．13〔八坂」1920，7．25『八坂』1921，9．6「東百」京

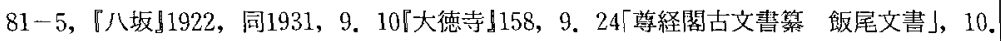
22 「綾部』「丹波安国寺文書」49，11，12「醍醐寺』1954，11．25「苯百」マ73，12．6丁壬生家』 586, 12. 15 「生源寺文書」東大影写本

1390 4. 11「松雲公採集遺編類纂 飯尾文䡒」，4．19「北野社家記録 目安等諸記録拔書」(『加能

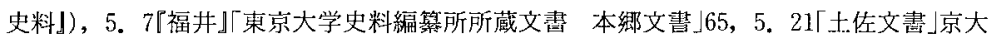

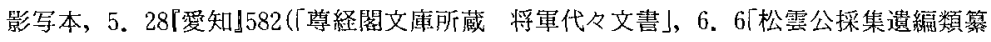

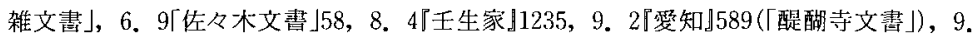
3 「天理図青館所藏文書」東大影写本，9．9【八坂」1932, 同增補49, 「祇園社記御神領部第十 一」(『八坂神社記録三』)，9.12「天竜寺重慧目録」，10．2「大德寺〕399，10.5「小早川家】 「小早川家證文」34，11. 25「長福寺」631，12. 24「高山寺』「高山寺古文書」185

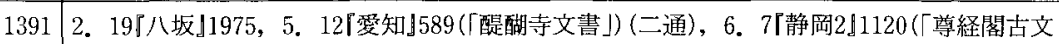

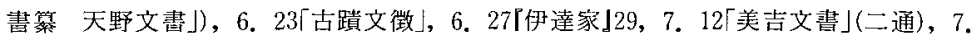
29「春日』34，8，7「妙興寺文書」187，「南北九州』6189(「薩摩櫵山文書」)，8．16「久我家』 132，8，21「实相院」京大写真帪，9．2「法金㴊院文書」京大影写本，11．13「南北九州』 6205(「筑前麻生文畫」)，12.2「石清水」「菊大路家文書」188 
1392 2. 6「園城寺 $711 ， 2$. 7 『壬生家』411(7), 「尊経閣古文書筑 大光明寺文青」，4．23「佐々 木」63，5．6丁壬生家」411 (8)，6．2「吉田文書」東大影写本，6．3「岐阜1㫙長善寺文畫」13，

6. 7 「天竜寺重書目録」，9.17亿島津家』273，10.23「天理図書館所蔵文畫」東大影写本，閏

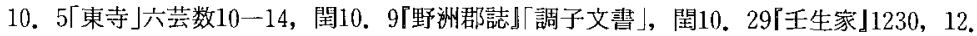
19「高野山』「宝簢集」299

1393 7. 8「東百」せ武63，7．16「上杉家』123(3)，7．22「松雲公採集遺編類纂134 美吉文書」, 「賀茂社諸国神戸記」(「大日史』明徳4年7月13日条)，7，30『南北中四】5544(「随心院文書」)， 8. 4「尊経閣古文書筑 宝落提院文書」，8．25「森田博三氏所藏文書」京大影写本，9.6『八 坂』1982，同2037，10．7「天竜寺重書目録」(「天章寺文害」88)，「大橋文書」東大影写本，11. 24「南北中四15569(「随心院文書」)，11．28「前田家所蔵文書 雑」京大影写本，12．7「東 百」せ武 64

1394 2. 27「醍醐寺』26函61，4．7『毛利家』1364，5．26『八咕』1516，7．28『八坂』增補75，8.

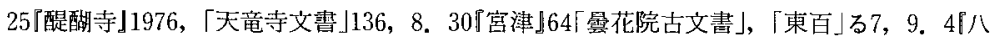
坂』2039，10.17『毛利家」1365，12．7「比牟礼八幡神社文書」京大影写本

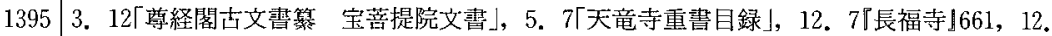
29 「東京帝国大学所蔵 青莲院文書」東大写真帳

1396 3. 28「八坂』1589，5．16「大徳寺』2991，5，18「八坂』1591，6，6醍醐寺』2625，6．27「宮

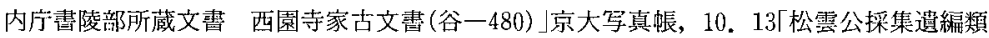

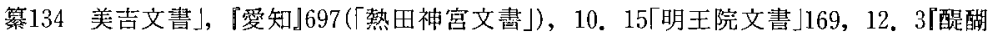
寺』2774

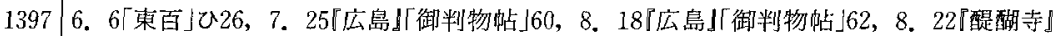
$2751 ， 8.28$ 福井】東京大学史料編等所所蔵文書 本郷文書」70，10.13『王生家』698, 11. 14「東百」才 $98 ， 11$ ．20「醍醐寺】 $2617 ， 11 ． 24$ 「東百」レ $85 ， 12$ ．13「東大寺」末成巻1-14一 009

1398 4. 13「法輪寺文書」東大影写本, 閏4. 18「醍醐寺』74, 同 $2752 ， 6$. 8「狩野文書」東大影写本, 6. 15「九条家』348，11。3「東大寺』「東大寺図書館架蔵文書」701，11．21「佐々木文書 78 , 12. $9\lceil\lceil$ 松雲公採集遺編類纂134美吉文書」

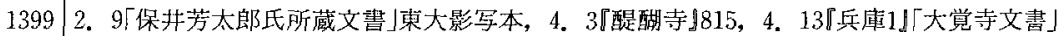
30，5．8「千種文書」京大影写本，6，13「松雲公採集遺編類箘134美吉文書」，6．15「九条 家」375(1)，6．20「醍醐寺』75，7．10「松雲公採集遺編類纂 136 飯尾文揞」，10．2「束百」 77, 10. 7「尊経閣古文書纂 東福寺文書」，11．24「岐阜4』「土岐文書」13

1400 2. 28「八坂』1938，闰1986，3．9醍醐寺』76，3．16「東福寺海蔵院文畫」東大影写本，4. 2 「高山寺】高山寺古文書」189，4．3「東大寺」末成巻1-24-322，4．13「兵庫8】「冷泉家文 書」40，4，26「作陽誌」(「大日本史料〕)，6，19「青蓮院文書」(『大日史』)，8．11「尊経閣古 文書纂 飯尾文書」，9．21「根岸文書」16，11．4丁静岡2」1279(「古文書雑箘」)，11．19「小 早川家』「小早川家証文 $5505 ， 12 ， 5$ 「京都東山御文庫所蔵文揞 諸家文書」京大写真帳， 12 . 24 尊経閣古文琵攻 石清水文書」

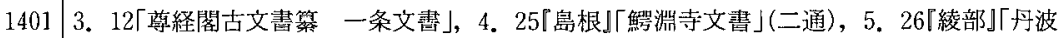

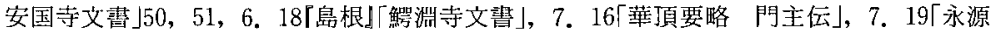

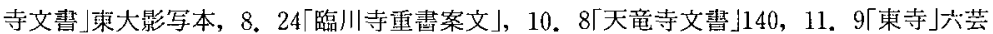
数 $11-8$,「春日」239, 「醍醐寺」26函 11 
室町幕府所務沙汰とその変質

\begin{tabular}{|c|c|}
\hline & 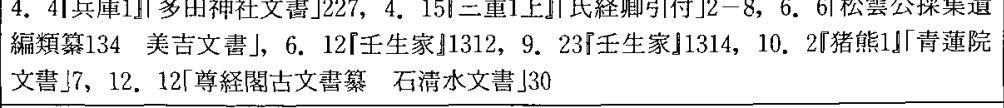 \\
\hline 1403 & 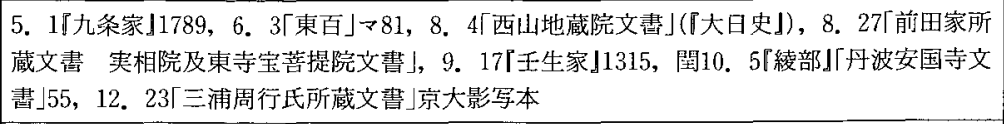 \\
\hline 1404 & 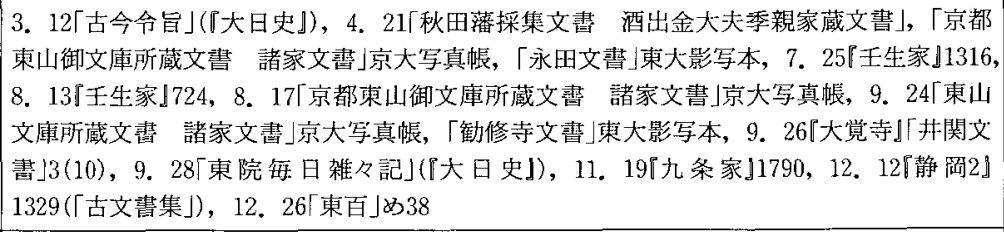 \\
\hline 1405 & 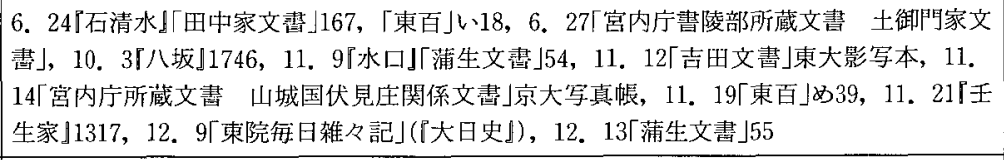 \\
\hline 1406 & 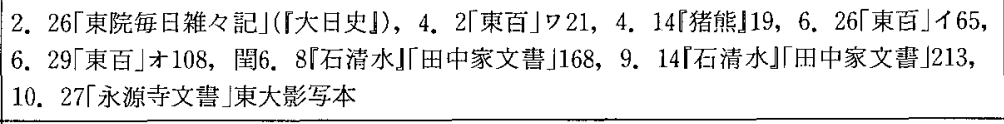 \\
\hline 107 & \\
\hline
\end{tabular}


別議にさ汰朝をさ倉れ訴続訟て府 伺・はれ・中当目れ期ら訟吉機はが個 ᄂ決こる御期該的た的れ機る関、打別 型裁の所前毛期とのなて関とが南こ領 には上務沙での主か所以説並北な主 変奉 5 沙汰の所るを務るそ明立朝っの 化行な汰な所務 ᄂ 人所機立務乷 てが務関、沙汰 ゆ個沙飞制沙の 别汰度市 二的機い的審 号

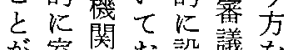
分室関投議老 判町吕こ定运示 明殿急なさ決柰

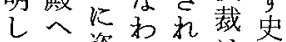
た伺姿九料

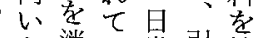
を消い常引㛟 立した的付鮧

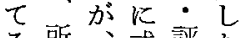
る所、式評た 形務南是結 式沙北運的果 の汰朝営仁 ○束唯政南 個審期な沙北
検沙とのさす期て所 討汰はれるい領 しのい屯て体将た知 制 い形民制軍裁行 室度が成たが主判や 町運たさ。形摧|年 幕営く礼し成の貢 府のた加さ場所納 所古検加儿机務入 務り討 沙方の 5 鎕を領汰ど 汰が余か倉京のに の本地、期怔催室関 特当が質々一の町卞 質汇あの同五場期る を室る違様世とへ訴 解町。いの紀いの訟 明期本が性半万展に 寸に稿視格は二開対 こ継、に市でのつ、 るるは野をまつにし

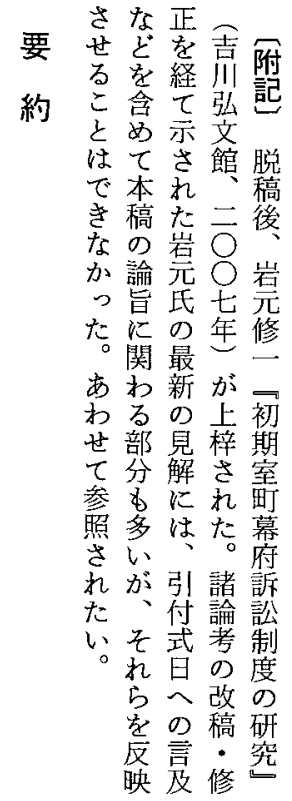

つこ訟二室、評序つたまし定合作朝う鎌訴は けらに方町そ価市た余給所内

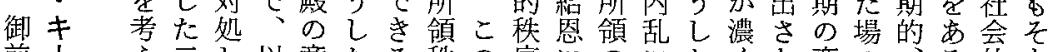

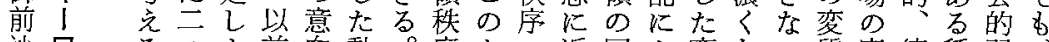
沙ワるつょ前问動。序よ・近回上変ない質廃徳種弱

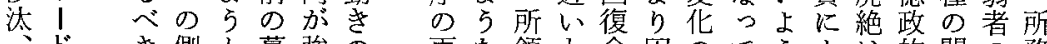
ドき側と幕強の 仁で面守府々結 政室あをる名及果 沙町 万と姿持び 汰幕 5 。勢つ弓京 にをてる都 視失い範

所野亏た囲領

務济こ一が主

沙入と定看社

汰机度出会

引 つな開れ

付、の放るの

式室で性し周

日幕当放加に

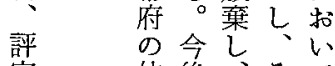

定位後々て 置は訴のは 再な領も命困のて 5 よは的開の務 編所秩の令難理いなっこな放救沙 の務序とをに由く個て亏政性済汰 動沙再す室なはの別、し治・をが 己汰構る町っ、で的室た規公すこ に制成こ殿だあな町政範正るう 深度へとと、つるも幕治が性たし いののでのとに。の府規存のめた 関変二、個いは的範在b、場 わ筫助室別 りは亡町的点従りる放てでら抏 を、李殿なか来、訴棄い裁のこ 持南ると関らの 所訟をた定訴な つ北、係説手縁対ま。訟わ わ朝と関に明続に忘意してをれ の末心係よでに左は味たい含て で期 あの意基付るるさ府るっらたた つ人味軸与。訴机法。てと多背 た的名と儿訟るを南市く景 之秩むしつ加裁度古北こるのに 


\title{
Shomu-sata of Muromachi-Shogunate and its Change
}

\author{
by Toru YAMADA
}

- key words : muromachi-Shogunate (室町幕府), Shomu-sata (所務 沙汰), Hikitsuke (引付), Hyoujou (評定), Gozen-sata (御前沙汰), Jinsei-sata (仁政沙汰)

In this paper I aim to consider whether Muromachi-Shogunate(13361573) inherited Shomu-sata(trial dealing with territorial troubles among lords) system from Kamakura-Shogunate(1185-1333), and to clarify the characteristic of Shomu-sata of Muromachi-Shogunate.

As a result of analysis, I point out following facts. Until the third quarter of 14th century Muromachi-Shogunate managed Shomu-sata in organized institutions, such as Hyoujou, Hikitsuke, Gozen-sata, and Jinsei -sata, like Kamakura-Shogunate. But in the last quarter of 14th century these institutions was abolished, and Muromachi-dono(the head position of Muromachi-Shogunate inherited by Ashikaga family) came to deal with appeals about territorial troubles individually. Therefore I conclude that this era was turning point for Shomu-sata of Muromachi-Shogunate.

Because Shomu-sata institutions were organized in order to deal a great number of appeals of lords, the abolition of them meant abandoning many appeals of weak lords. By this change, Shomu-sata management of Muromachi-Shogunate became individual and partial.

One reason for this change was that the Muromachi-Shogunate couldn't manage all appeals during and after the war. Another reason was that individual management was necessary for Muromachi-Shogunate to reorganize lords and their territories. 